2001 November 05

Cooperative Agreement

No. DE-FC07-98ID13666

Phase III Advanced Anodes and Cathodes Utilized in Energy Efficient Aluminum Production Cells

Final Technical Progress Report for the Period 1998 August through 2001 July (Revised 2002 May 07)

Submitted to:

U. S. Department of Energy Idaho Operations Office 850 Energy Drive Idaho Falls, Idaho 83401-1563 
DOE/ID/13666 - 1

\section{Phase III Advanced Anodes and Cathodes Utilized in Energy Efficient Aluminum Production Cells}

(Revised 2002 May 07)

Submitted to:

U. S. Department of Energy

Cooperative Agreement Number DE-FC07-98ID13666

Submitted by:

R. A. Christini

R. K. Dawless

S. P. Ray

D. A. Weirauch, Jr.

Alcoa Inc.

100 Technical Drive

Alcoa Center, PA 15069-0001

2001 November 05

This material is based upon work supported by the U.S. Department of Energy under Award No. DE-FC07-98ID13666. Any opinions, findings, and conclusions or recommendations expressed in this material are those of the authors and do not necessarily reflect the views of the Department of Energy. 


\section{TABLE OF CONTENTS}

$\underline{\text { Page }}$

1.0 Executive Summary .........................................................................................

2.0 Introduction .............................................................................................

2.1 Overall Objectives..................................................................................... 2

2.2 Proposed Program ......................................................................................

2.3 Summary of Proposed Project.......................................................................

2.4 Program Relation to Aluminum Industry Technology Roadmap................... 4

3.0 Critical Review of Technology Status..................................................................

3.1 Domestic Technology Status........................................................................

3.1.1 Oxygen Electrodes for Aluminum Smelting, DOE-Alcoa

Cooperative Agreement, 1980-1985 ………………………............. 6

3.12 Improvement of the Alcoa Cermet Anode - Pacific Northwest Laboratory Program......................................................................

3.1.3 Research on CEROX ${ }^{\mathrm{TM}}$ Coatings for Cermet Anodes, Eltech Research Corporation ....................................................................

3.1.4 Tests of a Prototype Cermet Anode at 120 A, PNL and Reynolds Metals ...................................................................................

3.1.5 Operational Results of Cermet Anodes in a Pilot Scale Test, Reynolds, Eltech, PNL, and Ceramics Magnetics.............................. 8

3.1.6 Assessment of New Cell Concepts, University of California at Berkeley..............................................................................

3.2 Worldwide Technology Status .......................................................................

3.2.1 Development of TINOR Coating and Novanor Inert Anode - Moltech 9

3.2.2 Plant Testing of $\mathrm{TiB}_{2}$ - Carbon Coating in Drained Cells - Comalco 9

4.0 Project Description ........................................................................................ 10

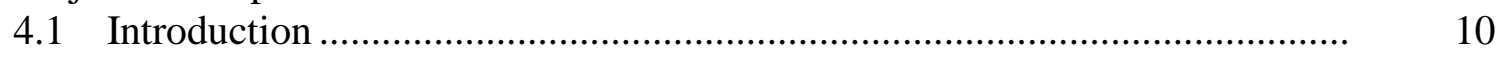

4.2 Proposed Concepts (Aluminum Partnerships) …………………................ 10

4.3 Technical Feasibility and Targets................................................................

4.4 Hurdles to be Overcome by the Proposed R\&D ........................................... 11

4.5 Economic Benefits ..............................................................................

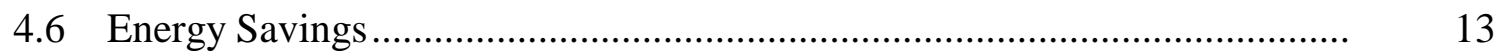

4.7 Environmental Benefits......................................................................... 14

4.7.1 Air Pollutants ............................................................................ 15

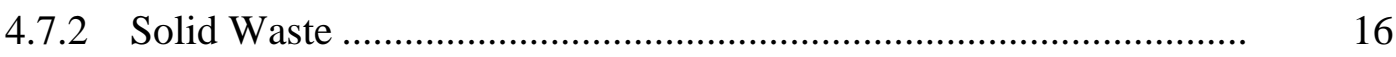

4.7.3 Changes in Hazardous Waste .......................................................... 16

4.7.4 Chemical Storage/Use ...................................................................... 17

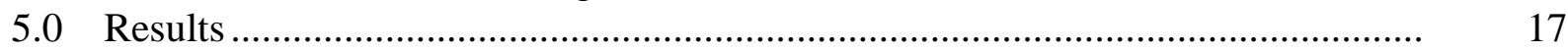

5.1 Results of Phases I and II ....................................................................... 17

5.2 Statement of Objectives for Phase III.......................................................... 19

5.3 Results of Phase III..................................................................................... 19 
Task 1: Planning and Management …………………………………......... 19

Task 1.1: Safety and Industrial Hygiene..................................................... 20

Task 3.2: Optimize Metal Content and Metal Phase Adders ........................ 23

Task 3.3: Optimize Ceramic Phase, Develop Advanced Anode Compositions 23

Task 3.4: Eltron Research, Inc. Anodes ...................................................... 33

Task 3.5: Scale-up and Improve Manufacturing, Characterize Anodes....... 34

Task 3.6: Build Pilot Anode Assemblies ..................................................... 43

Task 5: Development of Advanced Cathodes and Scale-up ........................ 44

Task 5.4: Cost-Effective Cathode Development.......................................... 45

Task 9: Bench Test of Anode Metal Phase ................................................. 75

Task 11: Bench Test of Anode Ceramic Phase ................................................ 81

Task 11.1: Horizontal Cell Bench Tests........................................................... 81

Task 11.2: Horizontal Cell Pilot Tests ........................................................ 82

Task 11.3: Autopsy Unit, Analyze Data..................................................... 84

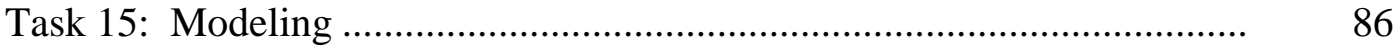

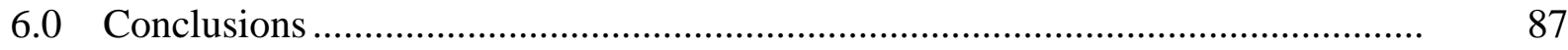

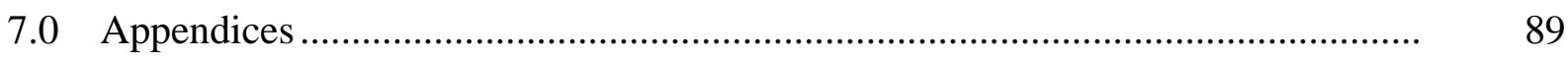

1. Fabrication of 1/2" Diameter Inert Anodes ................................................... 89

2. Patents Generated Under Contract ………………..................................... 91 


\subsection{EXECUTIVE SUMMARY}

During Phase I of the present program, Alcoa developed a commercial cell concept that has been estimated to save $30 \%$ of the energy required for aluminum smelting. Phase II involved the construction of a pilot facility and operation of two pilots.

Phase III of the Advanced Anodes and Cathodes Program was aimed at bench experiments to permit the resolution of certain questions to be followed by three pilot cells. All of the milestones related to materials, in particular metal purity, were attained with distinct improvements over work in previous phases of the program. $\mathrm{NiO}$ additions to the ceramic phase and $\mathrm{Ag}$ additions to the $\mathrm{Cu}$ metal phase of the cermet improved corrosion resistance sufficiently that the bench scale pencil anodes met the purity milestones. Some excellent metal purity results have been obtained with anodes of the following composition: $14 \% \mathrm{Cu}$, $3 \% \mathrm{Ag}, 83 \%$ composition $5301\left(51.7 \% \mathrm{NiO}, 48.3 \% \mathrm{Fe}_{2} \mathrm{O}_{3}\right)$.

Further improvements in anode material composition appear to be dependent on a better understanding of oxide solubilities in molten cryolite. For that reason, work was commissioned with an outside consultant to model the $\mathrm{MeO}$ - cryolite systems. That work has led to a better understanding of which oxides can be used to substitute into the NiO$\mathrm{Fe}_{2} \mathrm{O}_{3}$ ceramic phase to stabilize the ferrites and reduce their solubility in molten cryolite.

An extensive number of vertical plate bench electrolysis cells were run to try to find conditions where high current efficiencies could be attained. $\mathrm{TiB}_{2}-\mathrm{G}$ plates were very inconsistent and led to poor wetting and drainage. Pure $\mathrm{TiB}_{2}$ did produce good current efficiencies at small overlaps (shadowing) between the anodes and cathodes. This bench work with vertical plate anodes and cathodes reinforced the importance of good cathode wetting to attain high current efficiencies. Because of those conclusions, new wetting work was commissioned and became a major component of the research during the third year of Phase III.

While significant progress was made in several areas, much work needs to be done. The anode composition needs further improvements to attain commercial purity targets. At the present corrosion rate, the vertical plate anodes will wear too rapidly leading to a rapidly increasing anode-cathode gap and thermal instabilities in the cell. Cathode wetting as a function of both cathode plate composition and bath composition needs to be better understood to ensure that complete drainage of the molten aluminum off the plates occurs. Metal buildup appears to lead to back reaction and low current efficiencies. 


\subsection{INTRODUCTION}

\subsection{OVERALL OBJECTIVES}

The overall objectives of this program were:

- Reduction of the cost of primary aluminum production;

- Energy savings resulting from the improved performance of the Hall-Héroult cell (improvement of the Hall-Héroult process was one of the major goals of the Primary Product Sector Group at the workshop);

- Environmental benefits: reduction of perfluorocarbons, elimination of carbon monoxide and carbon dioxide emissions, the reduction of sodium and bath penetration and cyanide formation, and production of oxygen as a byproduct; and

- Market benefits: the lower cost of producing aluminum makes it a very attractive alternative to the U.S. transportation sector (motor vehicles, aircraft, and infrastructure uses, among others).

The passage of current between the anode and cathode is the major source of energy consumption in the process. Therefore, the reduction of the anode-cathode distance will improve the power and production efficiency of the process. Alcoa's energy efficient cell design consists of interleaved anode and cathode plates in a vertical array as shown in Figure 5.1-1 (page 17). This design also allows a reduction in current density which further provides energy savings. The potential electrical energy savings for an average U.S. industry aluminum smelting cell is approximately $1.7 \mathrm{Kwh} / \mathrm{lb}$ of aluminum produced if the proposed technologies are successfully implemented. This savings represents a huge $23 \%$ reduction in the electrical energy used in the smelting process.

\subsection{PROPOSED PROGRAM}

Our original application addressed advanced development of primary aluminum production defined in the "Aluminum Industry Technology Roadmap," recognizing industry goals for U.S. competitiveness through advanced process design and commercialization. Our objectives were to: Demonstrate advanced materials for inert anodes and wetted cathodes and an optimum design and process for smelting aluminum by designing, constructing, and operating advanced bench scale and pilot-scale aluminum smelting cells.

For over 110 years, the aluminum industry has relied on the traditional Hall-Héroult process for aluminum smelting, which is an extremely energy-intensive industrial process. The availability of advanced materials and technology have prompted the close examination of alternative smelting processes that can significantly reduce process energy requirements, thus reducing production costs and improving the competitiveness of the U.S. aluminum industry in world markets. Over 4 million tons of aluminum are produced annually by the U.S. aluminum industry. It is estimated that full-scale commercialization of the advanced process would reduce process energy consumption by 0.22 quad/yr., save the industry over $\$ 440$ 
million annually, and reduce $\mathrm{CO}_{2}$ emissions by 6 million tons per year. If energy savings are taken by reducing usage of coal fired power plants, total $\mathrm{CO}_{2}$ emissions can be reduced by 26.4 million tons per year. These savings would contribute significantly to revitalizing aluminum production.

Our proposed research effort was predicated on the successful results of previous DOEfunded research to develop a cermet anode that produces oxygen and a cathode material that is wetted by aluminum. The previous DOE-Alcoa Cooperative Agreement \#DE-PS0793ID13219 completed a design which produces in excess of a $20 \%$ reduction in the electrical energy used for aluminum smelting (hereinafter referred to as Phase I). Alcoa also demonstrated key elements of the overall cell design at bench scale, which provided confidence of operation at scale-up to a 1-5 kA pilot. Alcoa completed construction of this pilot cell facility, and ran two pilot cell tests as part of Phase II.

The objective of Phase III was to assess the long-term chemical stability of $\mathrm{NiO}-\mathrm{NiFe}_{2} \mathrm{O}_{4}-\mathrm{Cu}$ ceramic-metallic cermet anodes and stable wetted cathodes for energy efficient electrolytic production of aluminum.

\subsection{SUMMARY OF PROPOSED PROJECT}

The main purpose of Phase III was to demonstrate the "best available" and "optimized" anode and cathode materials and an overall cell design at a scale that minimizes cost, while providing sufficient size for confident scale-up to a commercial demonstration. Alcoa used an externally heated pilot scale cell, sized to operate at 1000-5000 amperes. The pilot scale anode was between a half- to full-scale of a commercial size, depending on the commercial design adopted. The advanced materials and cell design features tested during Phase III included:

- Advanced anode materials and design: considering wear rate, aluminum quality, thermal stresses, dimensions, collector bar connections, current distribution, and electrolyte flow;

- Advanced cathode materials and design: considering wetting, dimensions, wear, and release of carbon; and

- Anode and cathode durability and stability: considering breakage, cell start-up issues, and metal pad purity.

- Cell performance: considering voltage drop, current efficiency, current distribution, current density, and anode-cathode distance;

- Cell operability: considering length of continuous operation, sludge formation, alumina feeding, metal tapping, lid and sidewall design, and material problems;

- Electrode arrangement: considering electrolyte flow, alumina saturation, and aluminum collection; 
Major objectives for Phase III included:

- Cell operability - a minimum of one month of operation with no major problems such as sludge formation, difficult metal tapping, electrolyte loss;

- Cell performance - a total cell voltage drop less than 3.8 volts at $>93 \%$ current efficiency with operation at a 1 in. anode-cathode distance or less;

- Anode performance - breakage $(<10 \%)$ and metal pad purity $(<0.03 \% \mathrm{Ni}, 0.15 \% \mathrm{Fe} \&$ $0.10 \% \mathrm{Cu}$ );

- Alumina feed system - maintain alumina within a correct range to minimize wear and sludge formation; and

- Economic assessment of the cell design that gives a $25 \%$ ROI based on a retrofit implementation.

\subsection{PROGRAM RELATION TO ALUMINUM INDUSTRY TECHNOLOGY ROADMAP}

Alcoa's project is directly related to the primary aluminum production sector of the "Aluminum Industry Technology Roadmap." Competitiveness within the primary U.S. aluminum industry demands the low-cost production of aluminum. The key drivers in the production cost of primary aluminum are energy and production efficiency. Therefore, the objectives were aligned with the U.S. industry's needs. In addition to low costs, Alcoa is committed to the development of environmentally advantaged processes. The development of an oxygen producing anode for the Hall-Héroult process would eliminate carbon anode manufacturing with its production of polyaromatic hydrocarbons and the generation of $\mathrm{CO}_{2} / \mathrm{CO}$ during aluminum production and $\mathrm{CF}_{4}$ and $\mathrm{C}_{2} \mathrm{~F}_{6}$ during anode effect.

\subsection{CRITICAL REVIEW OF TECHNOLOGY STATUS}

\subsection{DOMESTIC TECHNOLOGY STATUS}

This section presents Alcoa's understanding of the current state of carbon electrode technology and reviews previous and ongoing research in the areas of oxygen electrodes and wetted cathodes.

Currently in aluminum processing, the inter-electrode spacing is not constant. The anode reaction occurs at the bottom of the carbon anode and the cathode reaction occurs at the top surface of the aluminum pool. The aluminum pool spans the entire bottom cavity of the cell and is tapped from the cell on a regular basis to keep the height of the pool between three- to five-inches. Because of high currents in the process (i.e., 150 to $250 \mathrm{KA}$ ), large magnetic fields are produced in the aluminum pool. The combination of the current and the magnetic field causes the aluminum pool to circulate, resulting in waves forming on the surface of the aluminum which can extend one inch above the normal height of the aluminum. If an aluminum surface wave hits an anode, electrical current passes without producing aluminum, 
resulting in a major loss of power and production efficiency. Because the inter-electrode space is constantly changing, the anode must be far enough away from the metal surface to avoid contact. Typically this distance is about $4.4 \mathrm{~cm}$ (1.75 in.). A cathode material that is wetted by aluminum and will drain such that the thickness of the remaining aluminum pool is less than $0.3 \mathrm{~cm}$ ( $0.125 \mathrm{in}$.), would eliminate the formation of waves. With a stable cathode surface, the constraint on the distance between the anode and cathode is eliminated, permitting the reduction of the spacing and the potential to improve power and production efficiency.

Anode changing can also cause waves on the aluminum surface of a cell that uses a deep metal pad. Because the anodes are consumed, they must be replaced every two weeks. This causes upsets in the distribution of the current, thermal field, and magnetic field in the cell. Upsets of this type initiate waves that result in a constantly changing spacing between the anode and cathode.

Combining an oxygen-generating anode, which has a life over one year, and a wetted cathode with a thin aluminum film that can be drained, results in a stable distance between the anode and cathode. This outcome, therefore, will achieve major improvements in energy and productivity efficiency for the Hall-Héroult cell.

- Many federal, industrial, and academic research and development activities have been conducted, including: "Oxygen Electrodes for Aluminum Smelting," DOE-Alcoa Cooperative Agreement, 1980-1985;

- "Improvement of the Alcoa Cermet Anode Developed under the 1980-1985 AlcoaDOE Cooperative Agreement," Pacific North West Laboratories (PNL);

- "Research on CEROX ${ }^{\mathrm{TM}}$ Coatings for Cermet Anodes," Eltech Research Corporation;

- "Tests of a Prototype Cermet Anode at 120 A," PNL - Reynolds Metals;

- "Pilot Scale Tests Aimed at Assessing Anode Manufacturing and Stability," Reynolds Metals, Eltech Research Corporation, and Ceramic Magnetics Inc.;

- "Water Models of Cell Concepts for Improved Electrolyte Flow," University of California, Berkeley;

- "Programs for $\mathrm{TiB}_{2}-\mathrm{G}$ Composite for Wetted Cathodes," Reynolds Metals and Great Lakes Carbon;

- "Materials and Cell Design for a Wetted Cathode," Comalco;

- "Studies of Low Temperature Slurry Electrolysis," Electrochemical Technology Inc.; and

- "Low Temperature Salt Systems for the Cermet Anode," DOE-Alcoa.

Summaries of selected research efforts, including the critical features leading to the current understanding of the technology are presented below. 


\subsubsection{Oxygen Electrodes for Aluminum Smelting, DOE-Alcoa Cooperative Agreement, 1980-1985}

The cermet anode, a key element of this program, was developed during the DOE Alcoa cooperative program between 1980-1985. The material is made of a mixed oxide ceramic and metal constituents, as the name implies. The mixed oxide phase contains $\mathrm{Ni}_{\mathrm{x}} \mathrm{Fe}_{3-\mathrm{x}} \mathrm{O}_{4}$, $\mathrm{Ni}_{\mathrm{y}} \mathrm{Fe}_{1-\mathrm{y}} \mathrm{O}$ and the metallic phase is a $\mathrm{Cu}$ rich phase containing a $\mathrm{Cu}-\mathrm{Ni}-\mathrm{Fe}$ alloy. The motivation behind the cermet formulation was combining the characteristics of high corrosion and oxidation resistance of a ceramic with a metallic phase to improve electrical conductivity, thermal shock resistance, and the ability to make connections to metal conductors. Other technologies developed during the cooperative agreement were processes for anode manufacturing (forming and sintering) and the cermet to metal conductor connections.

During this program, anodes were tested in commercial Hall-Héroult conditions at $60 \mathrm{~A}$ (at $1.0 \mathrm{~A} / \mathrm{cm}^{2}$ ) for 265 hours. Two critical tests of anode performance were the purity of the aluminum produced and anode wear. These tests showed that the $\mathrm{Cu}$-cermet performed the best. The purity of the aluminum produced was $0.19 \% \mathrm{Fe}, 0.18 \% \mathrm{Ni}, 0.10 \% \mathrm{Cu}$. The anode wear rate was estimated at $1.8 \mathrm{~cm} / \mathrm{yr}(0.70 \mathrm{in} . / \mathrm{yr})$. This material contained $17 \% \mathrm{Cu}$ and an oxide powder that contained $51.7 \% \mathrm{NiO}$ and $48.3 \% \mathrm{Fe}_{2} \mathrm{O}_{3}$. The oxide powder was designated 5324. The cermet was called 5324-17Cu.

It was believed that under optimum conditions, the cermet anode develops a passivating layer which leads to superior corrosion resistance. Cermet material fabrication practices and cell operating conditions can radically change the anodes' performance. These are the two important reasons why the cermet corrosion has varied so dramatically in previous tests.

\subsubsection{Improvement of the Alcoa Cermet Anode - Pacific Northwest Laboratory Program}

At the end of the Alcoa-DOE 1980-1985 cooperative program, PNL, under DOE contract continued the development of the cermet anode. Emphasis was in the following areas: 1) anode material development and evaluation; 2) development of wetted cathode materials; and 3 ) sensor development. The objective of the PNL cermet anode program was to further improve the corrosion performance and electrical conductivity of the cermet anode. PNL investigators experimented with compositional changes to the anode. Additions of aluminum were found to improve the electrical conductivity of the cermet significantly, but the corrosion performance of the anode degraded. PNL scientists recommended the 5324-17 Cu material developed by Alcoa as the preferred material for future cell studies. During the PNL work, the importance of controlling cell operating conditions on anode performance was recognized to be vitally important. The main concerns were the control of alumina and electrolyte composition. 
PNL staff also evaluated wetted cathode materials. The materials tested were Alcoafabricated $\mathrm{TiB}_{2}$ parts; Great Lakes $\mathrm{TiB}_{2}-\mathrm{G}$ plates; and a $\mathrm{TiB}_{2}$-based paint coating. Attempts also were made to produce in-situ $\mathrm{TiB}_{2}$ coating. The best results were obtained with Alcoa sintered $\mathrm{TiB}_{2}$ parts produced from $\mathrm{TiB}_{2}$ powders produced by plasma processing. During this program the $\mathrm{TiB}_{2}-\mathrm{G}$ produced mixed results. This was believed to be due to material and fabrication inconsistencies. But in recent long-term pilot tests at the Reynolds Metals Laboratories, $\mathrm{TiB}_{2}-\mathrm{G}$ has performed very well. $\mathrm{TiB}_{2}-\mathrm{G}$ is the preferred material today for wetted cathodes, however its cost is extremely high.

Alumina control in cells that used cermet anodes is very important. At low alumina concentration, the corrosion resistance of the anode degrades. Recently, Alcoa has developed a method for rapidly measuring alumina, which will be used to control alumina composition in the Phase III cell tests.

\subsubsection{Research on CEROX ${ }^{\mathrm{TM}}$ Coatings for Cermet Anodes, Eltech Research Corporation}

The Eltech program focused on the development of a coating to improve the corrosion performance of the cermet anode. Eltech demonstrated that the addition of cerium fluoride to the oxyfluoride electrolyte formed a cerium-oxyfluoride coating $\left(\mathrm{CEROX}^{\mathrm{TM}}\right)$ on the cermet anode. Corrosion tests conducted with and without cerium fluoride in the electrolyte showed substantial gains in the purity of the metal produced with cerium present, excluding increased cerium concentrations. However, the coating was not a good conductor, and therefore control of coating thickness was an important factor for achieving adequate current distribution, and minimizing the overall anode voltage drop. Poor current distribution and excessive anode voltage were found to degrade the anode corrosion performance and overall cell performance. A critical additional issue with this technology was the reaction of cerium fluoride with aluminum. This reaction formed cerium metal which reports to the aluminum pool and is an impurity in primary aluminum.

\subsubsection{Tests of a Prototype Anode at 120 A, PNL and Reynolds Metals}

The primary objective of this test was to determine if a commercially produced anode could survive normal Hall-Héroult cell conditions. The anode material was the Alcoa cermet. It was $15 \mathrm{~cm}$ in diameter and $20 \mathrm{~cm}$ high. The anode was operated at $0.50 \mathrm{~A} / \mathrm{cm}^{2}$, about $120 \mathrm{~A}$. The main conclusions from this study were as follows:

- Corrosion of the anode was higher than expected, after 120 hours of electrolysis, $6 \mathrm{~mm}$ were lost from the diameter of the anode;

- Oxidation of the cermet above the electrolyte was extensive;

- High cathode area relative to the anode area may have increased anode corrosion; and

- Mismatch of thermal expansion between the anode and the metallic conductor caused cracks in the anode. 


\subsubsection{Operational Results of Cermet Anodes in a Pilot Scale Test, Reynolds, Eltech, PNL, and Ceramics Magnetics}

The main objectives of this program were to demonstrate cermet manufacturing capabilities and test the cermet in a commercial anode configuration. The tests were conducted in an internally heated cell using a six-cermet anode array as a replacement for a standard Hall cell anode. The goal was to maintain $90 \mathrm{~A}$ per anode and $540 \mathrm{~A}$ for the six-anode array. The energy generated through electrolysis by the cermet anodes alone was not sufficient to achieve a cell energy balance at the desired operating temperature. Auxiliary energy was supplied by electrolysis between an adjacent carbon anode and an aluminum pool common to the carbon and cermet anodes. The carbon anode supplied most of the thermal energy required for cell operation. Tests of cerium free and cerium fluoride containing electrolytes were conducted. The anode material of choice for this test was the cermet developed by Alcoa during the 1980-1985 DOE cooperative agreement. Issues identified include:

- Anode breakage and cracks caused by the conductor to anode connection need to be corrected;

- Anode design must incorporate good current distribution and stress management;

- A Hall-Héroult cell that will operate near alumina saturation and not be operationally limited by muck formation is essential;

- Carbon anodes should not be used as auxiliary anodes to achieve the cell energy balance; and

- The composition, microstructure, and properties of commercial anodes should be the same as those achieved at a bench scale.

\subsubsection{Assessment of New Cell Concepts, University of California at Berkeley}

The objective of this program was to assess the design of new cell concepts for use with an oxygen producing anode and a wetted cathode. This study listed three critical factors that must be considered in the design of such a cell:

- Sufficient electrolyte velocity in the inter-electrode space to suspend and dissolve alumina;

- Adequate electrolyte velocity to achieve a negligible drop in alumina concentration from inlet to outlet of the inter-electrode space; while

- Minimizing fluid turbulence which influences reoxidation of aluminum.

Physical modeling was used to determine the influence of electrode orientation (horizontal versus vertical), the use and geometry of grooves in the anode, and the use of flow enhancers on the velocity, turbulence and ohmic losses in the inter-electrode space. The major findings were:

- The use and shape of grooves in the anode significantly influences the ohmic resistance in the inter-electrode space caused by gas evolution at the anode; 
- An anode without grooves operated in a horizontal configuration did not provide sufficient electrolyte velocity to keep alumina suspended;

- The near vertical electrode configuration had recirculating loops near the outlet flow from the inter-electrode space that would enhance reoxidation of aluminum; and

- The near horizontal electrode configuration was recommended because it minimized recirculation, achieved an adequate velocity, and because it reduced the ohmic gas resistance in the inter-electrode space with properly designed grooves.

The previous research review clearly shows the need for a design phase to address anode design, cathode design, cell design, flow design and cell control. Phase I accomplished this goal.

\subsection{WORLDWIDE TECHNOLOGY STATUS}

\subsubsection{Development of TINOR Coating and Novanor Inert Anode - Moltech}

Moltech has been aggressively investigating many new materials to improve cell performance or lifetime, and two are of interest. TINOR is Moltech's $\mathrm{TiB}_{2}$ coating used to produce a wettable cathode. Moltech has installed test coatings in eight smelters worldwide. Chemical analysis indicates that the coating lasts about three years (from Ti and B analyses in the tapped Al). Preliminary results show a dramatic reduction in Na uptake by the carbon cathode. If this lower $\mathrm{Na}$ uptake translates into less cathode growth, then the life of the pot should increase. Moltech has secured a \$4 million contract from the European Commission to test a pilot scale TINOR coated drained cell with conventional carbon anodes. Novanor, Moltech's inert anode, is the second material that relates to advanced cell concepts. In a recent paper, Sekhar et al. describe Moltech's research on a series of progressively more complex metal alloys as they attempt to develop an inert (stable, nonconsummable) anode.

\subsubsection{Plant Testing of $\mathrm{TiB}_{2}$ - Carbon Coating in Drained Cells - Comalco}

Comalco has been testing their $\mathrm{TiB}_{2}$ cathode coating in drained cells in one of their smelters for about 10 years. Comalco's coating is a mixture of $\mathrm{TiB}_{2}$ and $\mathrm{C}$ produced by baking out a mixture of $\mathrm{TiB}_{2}$ and a carbonaceous cement. The coating permits good wetting of the $\mathrm{Al}$ and close anode-cathode distance in their drained cells. Coating life appears to be the problem as the $\mathrm{Al}$ metal pad apparently reacts with the carbon portion of the cement to produce $\mathrm{Al}_{4} \mathrm{C}_{3}$. Thus the carbon portion of the coating slowly disappears; simultaneously releasing the $\mathrm{TiB}_{2}$ particles. The coating typically lasts 700 days . Once the coating is gone, the Al rapidly reacts with the carbon underneath leading to cell failure. Until Comalco can increase the lifetime of their coating, it does not appear that they can expand their test beyond the limited group of test pots.

\footnotetext{
${ }^{1}$ G. D. Brown et al., "TiB 2 Coated Aluminum Reduction Cells: Status and Future Direction of Coated Cells in Comalco," Proceedings of the $6^{\text {th }}$ Australian Aluminum Smelting Workshop, 1998, edited by B. J. James, M. Skyllas-Kazacos, and B. J. Welch.
} 


\subsection{PROJECT DESCRIPTION}

\subsection{INTRODUCTION}

Our objectives in this program were to:

- Demonstrate advanced materials for inert anodes and wetted cathodes and an optimum design and process for smelting aluminum by designing, constructing, and operating advanced bench scale and pilot-scale aluminum smelting cells;

- Develop advanced materials which can be used to produce cost effective inert anode and wetted cathodes for Alcoa's optimum cell design;

- Develop advanced materials and concepts for insulated lid and sidewall;

- Operate within all contractual, professional, regulatory, and policy guidelines established by DOE; and

- Apply the highest level of academic and professional credentials, organizational quality, and corporate commitment to the conduct of all task assignments.

\subsection{PROPOSED CONCEPTS (ALUMINUM PARTNERSHIPS)}

Alcoa's cell concept uses vertical parallel plates with reduced anode to cathode spacing and reduced current density on the plates to achieve significant energy savings. Alcoa's energy efficient cell concept is predicted to be capable of reducing the electrical energy intensity of aluminum production from $15.8 \mathrm{Kwh} / \mathrm{kg}$ to $12.1 \mathrm{Kwh} / \mathrm{kg}$. This is better than the short-term performance target for the Primary Products Sector of $13 \mathrm{Kwh} / \mathrm{kg}$ defined in Exhibit 12 of the Aluminum Technology Roadmap Workshop Report. It is a major step toward achieving the long-term performance target of $11.0 \mathrm{Kwh} / \mathrm{kg}$. It is theoretically possible for Alcoa's concept to eventually achieve the long-term objective of $11.0 \mathrm{Kwh} / \mathrm{kg}$, which requires a total cell voltage reduction from 3.8 volts to 3.4 volts and minimal heat losses. The cell technology would have to be advanced using Alcoa proprietary concepts to include an inert sidewall, high conductivity anodes with low corrosion rates, an anode to cathode distance reduction from 1.0 inch to approximately 0.5 inch (depending on further current distribution modeling), optimization of electrolyte chemistry and operating temperature, and elimination of some electrode penetrations by creating compartments within the cell.

Alcoa's energy efficient cell concept also will eliminate anode carbon, $\mathrm{CO}_{2} / \mathrm{CO}$ emissions during smelting, and the generation of perfluorocarbons (PFCs). Since this cell concept produces oxygen instead of $\mathrm{CO}_{2} / \mathrm{CO}$, there is potential to concentrate this material for sale as a valuable byproduct. These are all performance targets for the Primary Products Sector defined in Exhibit 12. This cell concept has the potential for reducing the cost of aluminum production by over $13 \%$ based on Phase I calculations. These do not include the aforementioned advanced concepts for reducing cell voltage, byproduct credit for oxygen, or 
capital implications. The projected reduction if realized would be a major step toward the Exhibit 12 performance target of a $25 \%$ reduction in the cost of aluminum reduction.

\subsection{TECHNICAL FEASIBILITY AND TARGETS}

The aluminum industry has known for some time that reducing the anode-to-cathode distance and/or providing high electrode surface area in Hall-Héroult cells is the logical approach to conserve energy in aluminum production. Using cermet anodes and stable cathodes in synergism in Alcoa's energy efficient cell concept will revolutionize the production of aluminum by dramatically reducing energy costs and/or increasing productivity, and eliminating the carbon plant. Currently, an inert anode cell for aluminum production is not economical because anode wear rate and subsequent aluminum contamination is too high, and because of the high capital investment necessary for anode and cathode materials.

The deliverables for Phase III are bench scale and pilot scale demonstrations proving:

- Metal purity acceptable as Alcoa commercial quality aluminum with proposed limits of $0.15 \% \mathrm{Fe},<0.03 \% \mathrm{Ni}, 0.10 \% \mathrm{Cu}, \mathrm{Si}<0.10 \%$ and the total of all other metals being $<0.055 \%$;

- Cost effective anode and cathode materials and designs

- Projections for electrodes lifetimes of 1000 days and other materials (sidewall, lid, and bottom) lifetimes of at least 1300 days;

- An average current efficiency of $93 \%$ and 3.8 volt anode to cathode potential drop at a superficial anode current density of at least 0.8 amperes $/ \mathrm{cm} 2$;

- $\quad 1.7 \mathrm{Kwh} / \mathrm{lb}$. energy savings;

- A major reduction in $\mathrm{CO} / \mathrm{CO}_{2}$ and fluoride emissions; and

- A $25 \%$ return on assets.

\subsection{HURDLES TO BE OVERCOME BY THE PROPOSED R\&D}

It is critical that anode corrosion be reduced to meet metal purity requirements. The proposed materials research will optimize the metal phase amount and composition and the ceramic phase composition. Advanced material concepts will also be considered. This coupled with an optimized cell design is expected to reduce anode corrosion by at least a factor of 3 . The preferred concept is capable of accommodating advanced materials and designs for achieving this goal; and continued bench scale and pilot scale research with Alcoa's concept will address this problem. Design features of the energy efficient cell, which are relevant, follow:

- The circulation design provides a region of intense mixing for dissolving alumina feed which will help achieve nearly saturated bath which reduces anode corrosion;

- The circulation design gives sufficient flow into each array of vertical plates to prevent significant depletion of alumina but at low velocities such that anode corrosion is not enhanced and current efficiency is not decreased; and 
- The circulation design provides locations for gettering bath impurities and sludge before entering the electrode compartment or metal pad to improve metal purity.

Alcoa has worked with DOE to develop and advance cermet anode materials and has worked internally on novel materials for stable cathodes for this particular process. Alcoa is in the position to immediately focus its efforts on optimizing, testing and producing more costeffective materials and the development of an energy and production efficient aluminum smelting process. Alcoa's general approach, which is covered in Section 4, includes a roadmap of major activities, decision points, and task interrelationships.

\subsection{ECONOMIC BENEFITS}

During Phase I, a cost model was developed for a five-line 131 kiloampere $(\mathrm{kA})$ Alcoa smelting plant. The model was constructed to compare the conventional smelting process and a selected energy efficient cell concept. The primary measurement criteria is cash cost difference per pound of aluminum. The comparison is based on material cost and consumption and with savings in energy and labor. Several of the basic support services in the conventional process remain the same in the energy efficient concept.

Table 3-1 gives the base case for the economic assessment and the associated incremental savings for an Energy Efficient Cell Concept that was completed during Phase I. This estimate is based on a retrofit scenario and does not include capital cost. The cost of electrode assemblies and refractories for cell relining are built into the R\&M costs. Cell design modifications to convert cells from conventional to energy efficient were too preliminary to make reasonable capital estimates. Capital implications will be included in the Phase III economic assessment and will be aided by the experience of the pilot cell construction.

\begin{tabular}{|l|c|}
\hline BASIS & SAVINGS (\$/lb. Al) \\
\hline Base Case & \\
\hline Anode life of 1095 days, & \\
Cell life of 2000 days, & \\
\$35/lb 5/8" thick TiB 2 cathode plates (recycled), & \\
17\% Cu cermet anode with 0.7" wear/yr. & $(0.002)$ \\
Differential material cost & 0.026 \\
1.3 Kwh/lb savings at 20 mil power cost & $\underline{0.024}$ \\
Elimination of carbon - labor savings & $\mathbf{0 . 0 4 8}$ \\
Total Base Case Savings & 0.011 \\
\hline Other Benefits & $\underline{0.012}$ \\
\hline \$10/lb 5/8" thick TiB 2 cathode plates (recycled) & $\mathbf{0 . 0 7 1}$ \\
20\% increase in capacity with 27\% Cu anode & \\
\hline Total Savings & \\
\hline
\end{tabular}

Table 4-1: Base Case for Economic and Savings Assessment 
As shown, the project cash cost savings of this Phase I cell design is between $5 \varnothing$ to $7 \varnothing$ per pound of aluminum, without capital implications. These cost and energy savings also would affect the nation economically. Lowering the cost of aluminum production will increase the industry's competitiveness in U.S. markets, thereby increasing production requirements and direct industry employment. Secondary benefits are the energy savings and socioeconomic improvements that can result from the use of aluminum for energy savings in the U.S. transportation industry. Taken together, the technological, energy, environmental and socioeconomic benefits that may result from commercializing advanced aluminum production will significantly improve the competitiveness of the U.S. aluminum industry. Because Alcoa is one of the major stakeholders in the aluminum industry, we are committed to bringing this advanced process to full commercialization, and improving the viability of the U.S. aluminum industry.

\subsection{ENERGY SAVINGS}

One of the major incentives for conducting research in this area is the potential savings that can be achieved in energy efficiency. With the oxygen anode and a drained, wetted cathode, a dimensionally stable inter-electrode spacing will be created. This will permit a smaller distance between the anode and cathode. The pot stability and reduction in anode and cathode space allows for major improvements in energy and productivity efficiency. Past work on this project by Alcoa has shown that if the anode/cathode distance could be reduced to 0.75 inches compared to the present 1.75 inches, a $23 \%$ decrease in energy requirements could be achieved. Additional energy savings may result from improved current efficiency and possibly lower pollution control energy.

In Phase I, the goal of the thermal design of the Energy Efficient Aluminum Smelting Cell that uses an oxygen generating anode and a wetted cathode was to specify a cell lining and operating conditions that minimize heat losses while maintaining cell productivity and operability. The information developed was used to establish material requirements, energy needs and cell productivity for economic assessment of the design. To evaluate different commercial design concepts, Alcoa's proprietary cell energy balance computer model, called HTBAL2d, was used. The commercial design resulting from the modeling work features a highly insulated cell operating at 3.8 volts. Comparative energy efficiencies are summarized in Table 3-2 below. Depending on the basis used for comparison, energy savings between $17 \%$ and $38 \%$ are realized for Alcoa Hall cells with the new design. This design is based on an anode/cathode distance of 1.0 inch (and a reduced current density between vertical plates) which is conservative compared to the 0.75 inch spacing used in prior work. Another estimate was made based on an average domestic industry consumption of $7.2 \mathrm{Kwh} / \mathrm{lb}$ of aluminum and assuming carbon baking energy requirements and usage are similar to Alcoa's. That table is also shown below. The difference in total thermal energy from the environment in the last table is $7.8 \mathrm{~kW}$, which is equivalent to $2.34 \mathrm{~kW}$ of electrical energy at a power plant efficiency of $30 \%$. 


\begin{tabular}{|l|c|c|c|}
\hline \multicolumn{1}{|c|}{ Basis For Comparison } & $\begin{array}{c}\text { Alcoa Hall } \\
\text { (Kwh/lb) }\end{array}$ & $\begin{array}{c}\text { Inert Anode } \\
\text { (Kwh/lb) }\end{array}$ & $\begin{array}{c}\text { Savings } \\
\text { With Inert } \\
\text { Anode }\end{array}$ \\
\hline Elect. Energy at Pot & 6.69 & 5.52 & $17 \%$ \\
\hline Total Energy to Potrooms & 8.36 & 5.52 & $34 \%$ \\
\hline Total Energy to Smelter & 8.89 & 5.52 & $38 \%$ \\
\hline Total Energy from Environment & 24.5 & 18.4 & $25 \%$ \\
\hline
\end{tabular}

\begin{tabular}{|l|c|c|c|}
\hline \multicolumn{1}{|c|}{ Basis For Comparison } & $\begin{array}{c}\text { USA Hall } \\
(\text { Kwh/lb) }\end{array}$ & $\begin{array}{c}\text { Inert } \\
\text { Anode } \\
\text { Kwh/lb) }\end{array}$ & $\begin{array}{c}\text { \% Savings } \\
\text { With Inert } \\
\text { Anode }\end{array}$ \\
\hline Elect. Energy at Pot & 7.2 & 5.52 & $\begin{array}{c}23 \% \\
(1.7 \mathrm{~kW})\end{array}$ \\
\hline Total Energy to Potrooms & 8.87 & 5.52 & $38 \%$ \\
\hline Total Energy to Smelter & 9.4 & 5.52 & $41 \%$ \\
\hline Total Energy from Environment & 26.2 & 18.4 & $30 \%$ \\
\hline
\end{tabular}

Table 4-2: Summary of Energy Efficiencies

It has been projected by DOE that the use of cermet anodes or stable cathodes would result in savings of approximately $1 \mathrm{Kwh} / \mathrm{lb}$ of produced aluminum. In addition, if cermet anodes and stable cathodes were used together, DOE projects that an energy savings of $2.4 \mathrm{Kwh} / \mathrm{lb}$ of produced aluminum could be realized. A substantial national energy savings of .22 quad/year could be realized, assuming a current average use of $7.2 \mathrm{Kwh} / \mathrm{lb}$ with a national production of 4 million metric ton/year.

In terms of national electricity consumption, the potential savings resulting from full commercialization is significant. For example, the aluminum industry currently consumes approximately $2.3 \%$ of the nation's electricity for aluminum smelting. Full commercialization of advanced production technology could realize a $30 \%$ savings, reducing consumption to approximately $1.6 \%$ of the nation's electricity.

\subsection{ENVIRONMENTAL BENEFITS}

The environmental benefits for the preferred energy efficient cell concept are as follows:

- Elimination of carbon anodes eliminates carbon monoxide, carbon dioxide, and fluorocarbons;

- Top entry electrodes and titanium diboride coatings and minimal current to sidewall and bottom of cell will reduce sodium and bath penetration and cyanide formation with the potential to eliminate these problems; and

- Stable electrodes and stable cell operations will reduce fluoride and dust emissions with significant improvements in environmental impact, safety, and working environment with the potential to eliminate fluoride emissions. 
If energy savings are taken by reducing usage of coal fired power plants, total $\mathrm{CO}_{2}$ emissions can be reduced by 26.4 million tons per year.

\subsubsection{Air Pollutants}

Historically, the production of green anodes from carbon and petroleum-based materials and the calcination of those anodes in commercial aluminum production has been associated with certain air contaminants. The proposed change in producing anode raw materials from a carbon to a ceramic/metallic base, would eliminate the emission of these contaminants. If the production of green anodes/anode calcination were eliminated, the air contaminants associated with those processes such as dust, tar volatiles, tar particles, gaseous and particulate fluoride, $\mathrm{CO}, \mathrm{CO}_{2}, \mathrm{SO}_{2}$, and $\mathrm{NOx}$ would likewise be eliminated. In addition, the use of carbon anodes is responsible for air contaminants in the smelting process as well. If carbon anodes were no longer used in smelting, the contaminants $\mathrm{CO}, \mathrm{CO}_{2}, \mathrm{SO}_{2}, \mathrm{PAH}, \mathrm{CF}_{4}$ (during anode effect) and some fluorides would be eliminated.

Since the oxygen anode is expected to last roughly 25 times longer than the carbon anode, there will be less intrusion into the pot to replace them, allowing for less fluoride to escape during this disruption. Less disruptions (i.e., pot crust breakage and pot cover removal) should substantially lower the facilities' overall fluoride emissions.

In the scenario where Alcoa would build a commercial oxygen anode facility, certain air contaminants would be expected. The processing steps for manufacturing oxygen anodes are grinding, mixing, calcining, blending, and burn off of the organic binder that is used as a consolidation aid for the $\mathrm{Fe}_{2} \mathrm{O}_{3}, \mathrm{NiO}$, and $\mathrm{Cu}$ powders. Each of these unit processes would need to be evaluated regarding nickel compounds, which are listed carcinogens and also Hazardous Air Pollutants under the 1990 Clean Air Act Amendments. One redeeming feature about the air emissions in the case of the oxygen anode is that virtually all of the emissions will be in the form of metal and ceramic particulates for which there are well developed control technologies. Further, all of Alcoa's facilities are equipped with these control technologies, and we are familiar with the requirements and control specifications.

One process that will require attention will be the burn off of the organic binder, which is used as an aid to form the cermet material. Current binder systems include industry staples such as PVA, PVB, and Carbowax. Since these binders are used extensively, air pollution control systems should be readily available for the organic emissions.

The cermet anode will generate large amounts of oxygen and there are expectations that the cell design could be enclosed to capture this oxygen as a valuable by-product. The enclosure would allow for a more pure by-product and would decrease the generation of fluorides (through less fluoride equilibriating with the anode gas). However, a technical hurdle must be overcome to allow for the pot enclosure. For instance, the current anode gas system 
allows for vital pot structure cooling and there are handling problems associated with relatively pure sources of oxygen at the elevated temperatures of pot exhausts.

Another issue is that the oxygen anode facilities will most likely represent a new source and/or major modification within the aluminum industry. New sources of air emissions are generally required to meet more rigorous permitting standards for New Source Performance Standards (NSPS) or New Source Review (NSR). Associated emissions will require better control technologies and in many cases longer lead times for permit approvals.

At the project level, it is anticipated that associated emissions will require a state permit. Alcoa is thoroughly familiar with the Pennsylvania permitting requirements so that all project activities will be in compliance from the project's initiation.

\subsubsection{Solid Waste}

With the curtailment of carbon anode operations, certain carbon plant solid wastes would be eliminated. For carbon anode facilities with wet scrubbers, the wet scrubber sludge would be eliminated. Analogously, for those plants that have dry scrubbers, solid dry scrubber waste would be eliminated. Additionally, many carbon plants generate refractory brick from the calcining operation, rod blast collector catch, butt blast collector catch, waste coal tar pitch, and dust collector bags; and these would likewise be eliminated. Typical carbon anode production processes generate thousands of tons of the above wastes per year. Much of the waste is sought for beneficial use because of its carbon or fuel value. Many facilities have programs to dispose of these materials through cement kilns or through other recovery processes.

With the production of cermet anodes for commercial production there will be some solid wastes generated. These wastes include waste ceramic materials, nickel and iron wastes, and off-specification and used anode material. According to the Resource Conservation and Recovery Act, these wastes should be non-hazardous industrial waste. However, with the concerns raised about nickel compounds, these materials will need to be handled to ensure proper industrial hygiene and environmental protection.

Similar to the air permit discussed above, it is likely that even at this pilot project level, an industrial waste disposal permit will be required from the state. Alcoa works continually with the Pennsylvania environmental regulations, is thoroughly familiar with the procedures, and ensures that applicable permits will be received prior to the Program's implementation.

\subsubsection{Changes In Hazardous Waste}

Barring incidental use of extraneous materials (i.e., solvents for clean-up), virtually all of the waste materials generated from the carbon anode processes are considered non-hazardous industrial waste. According to the Resource Conservation and Recovery Act, the solid wastes associated with commercializing this advanced aluminum production technology 
would be classified as non-hazardous. However, certain states (and EPA) have tried to list nickel compounds in the toxicity characteristic for determining whether a waste is hazardous. These efforts should be reviewed.

\subsubsection{Chemical Storage/Use}

Carbon anode facilities store large amounts of petroleum coke and pitch. The coke material is conveyed by screw conveyers or pneumatically blown into large (i.e., 200,000 gal.) tanks or silos and the pitch is received generally in liquid-form from railroad cars and stored for use in 100,000 gal. above-ground storage tanks. The coke causes dusting during various conveyance and handling activities and the liquid pitch has the potential to spill while being unloaded or stored. "Green" anodes have the potential to leach organic constituents and must be stored in a manner that restricts contact with water. Likewise, the anode "butts" and "fish butts" can leach organic and inorganic contaminants and must be stored under roof.

At a commercial scale, certain storage and use precautions would need to be implemented. The nickel compounds must be stored in a manner which precludes dusting and skin contact. One way to diminish the effect of the nickel compounds is to buy the powder in mixed (with iron compounds) forms. Another way is to store the nickel and other metals and dusts in closed containers. Generally material storage will be less encompassing than for the carbon anodes because many fewer oxygen anodes will be needed for smelting operations.

\subsection{RESULTS}

\subsection{RESULTS OF PHASES I AND II}

During Phase I of the present program Alcoa developed a commercial cell concept that has been estimated to save $30 \%$ of the energy required for aluminum smelting, starting from fossil fuel. The concept has been designed into a vertically arranged anode-cathode assembly, Figure 5.1-1. An improved cermet anode composition was also developed that has an electrical conductivity an order of magnitude greater than the previous composition. Initial tests on the corrosion performance of the material were encouraging. The high conductivity will provide opportunities for increases in cell capacity while maintaining energy savings, thus creating greater economic value. During Phase I the pilot cell design was also developed and key components of the design tested. 


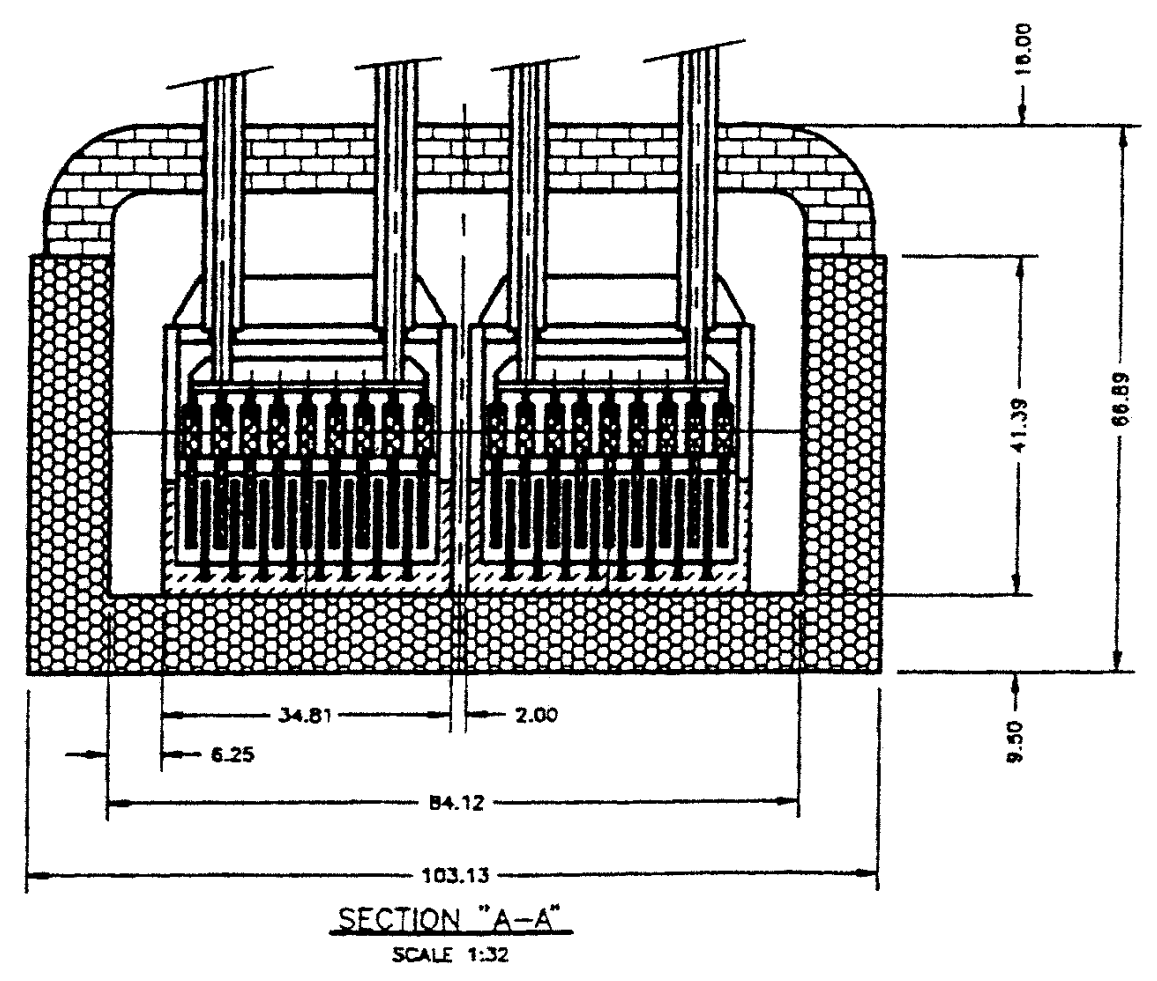

Figure 5.1-1: Vertically Arranged Anode-Cathode Assembly

During Phase II, construction of the pilot cell facility, joining of the anodes to metal connectors, fabrication of the anode modules, and installation of all cell internals were completed. The original method for joining the anode to the connector did not work and an alternative was successfully developed. Joining of the cermet anode to a nickel connector was accomplished by reducing the ceramic (oxide) portion of the anode to form a metal alloy in a short section at the top of the anode plate. This was then diffusion welded to the nickel connector. The first pilot cell run was made in December, 1997. The electrolyte was melted in a separate furnace and transferred into the cell by pressure tapping. Initially, the equilibrium potential obtained by volt-amp curves was too low indicating a problem such as aluminum on the anode or a lower voltage reaction. For one module, this was corrected by argon lancing of the electrode plates and compartments. The total cell resistance was then lower than expected corresponding to a total cell voltage drop ranging from 2.95 volts to 3.67 volts compared to the program objective of 3.8 volts or less. If a commercial cell current efficiency $>93 \%$ can be projected from pilot cell operations, the energy savings objective can be met. Cell sludging precluded an adequate determination of current efficiency from this first pilot cell test. Current efficiency was crudely estimated for 6 hours of the first test to be $78 \%$ to $87 \%$ by alumina depletion. For this scale unit, this is a good result. There was no indication of any high voltage problems. This implies that all critical interfaces had low voltage drops. This would include the oxygen gas film at the anode, cathode over potential, cathode connector to molten aluminum interface, the reduced alloy at the top of the cermet anode, and anode connector welds. The anodes, anode modules, cathode plates, and 
Monofrax side walls maintained structural and dimensional integrity during startup and operation. One module operated periodically at 2.5 times nominal current without known thermal shock failure of anodes or support structure. The electrolyte level was maintained by aluminum fluoride additions to correct for vapor losses and did not require the sodium fluoride additions used in a Hall cell. This indicates minimal sodium and electrolyte penetration of the crucible.

Power to the pilot cell was provided by low voltage heaters in the thick side wall of a large graphite crucible with heat transfer primarily through the high thermal conductivity bottom into the cell. The design also included a well insulated lid. The unit demonstrated a maximum bath temperature capability of at least $976^{\circ} \mathrm{C}$, and the cell operated without a top crust until sludging became a problem. This indicates low heat losses from the top as required to achieve the energy savings objectives of the program. Ancillary equipment for the pilot cell facility including the electrolyte melting furnace, the transfer line and power supplies all worked well.

The objectives of Phase III were to develop higher performance and lower cost materials for both the anode and cathode, to maximize the economic impact and to address any operating or design concerns at the end of Phase II.

\subsection{STATEMENT OF OBJECTIVES FOR PHASE III}

The objective was to develop a high level of confidence in the commercial viability of an "Energy Efficient Aluminum Production Cell" through advances in anode and cathode materials which are proven by bench scale and pilot scale demonstrations that use $\mathrm{O}_{2}$ evolving anodes and wetted cathodes to achieve a $30 \%$ reduction in the energy usage. Success was to be based on cell operability, metal composition, anode wear rate, energy efficiency, and economic and environmental viability.

\subsection{RESULTS OF PHASE III}

Results will be reported by task. The original task statement will be at the beginning of each task in bold. Results and conclusions within each task will follow.

\section{TASK 1: PLANNING AND MANAGEMENT}

This task will provide for the project direction, planning, scheduling, monitoring, and reporting of technical and financial status during all of Phase III. Status reports at sixmonth intervals of the project will be written. Individual topical reports will be prepared as indicated in the tasks for Phase III, and an overall Phase III Report will be written.

An anode manufacturing team was formed to establish a program for development of the next generation anode design. Team members were S. Ray, D. Roha, L. D'Astolfo and M. Bruno. 
Critical characteristics and related tasks were identified relative to anode robustness, rod and joint design, bath circulation, and anode design.

The team met and reviewed the Phase I report which categorized and ranked the many characteristics and properties both of the anode and the cell design which impact anode performance. Anode properties such as electrical conductivity and thermal expansion were assessed to minimize heat generation within the anode and to make any thermal expansion changes compatible with the joint design. Rod and joint designs were evaluated to produce minimum stress on the cermet portion of the anode. Slotting of the anodes was incorporated to enhance circulation and thus gas bubble removal and also alumina supply to the anode.

Quarterly reports were written to update progress on the project. Annual reports were written that summarized the work of each of the first two years. This report constitutes the overall Phase III report mentioned above.

\section{Task 1.1 - Safety and Industrial Hygiene}

There was no specific task on safety and industrial hygiene. However, concerns about the possibility of a thermite reaction if the anode contacted the molten aluminum led to a number of experiments to understand the hazard. Other miscellaneous safety and industrial hygiene activities will also be reported here.

The objective of the thermite reaction program was to access the severity of possible reactions that could occur during the operation of inert anodes in an electrolytic cell environment and determine if these reactions could be modified or controlled so that the cell could be operated safely.

A walk-in hood was installed and put into operation with the necessary electrolysis cell, electrical outlets, exhaust stack, data logging system, lights, power supply, safety doors, anode positioning cylinders, air stream monitor, and video camera.

Pencil anodes were mounted on a stand that can be lowered into the electrolysis cell whereby the depth and speed of lowering can be controlled. The electrolysis cell was initially run under normal parameters for pencil anodes. The voltage to the anode was increased to overheat the anode to determine if and when a reaction could be set off. The following anodes have been tested:

1. Regular length pencil anodes in bath/metal electrolysis cell.

2. Regular length pencil anodes in an electrolysis cell without bath.

3. Pencil anodes shortened to 1 inch with a cone shaped end in an electrolysis cell without bath.

4. Pencil anodes shortened to 1 inch with a square cylinder end in an electrolysis cell without bath. 
5. Larger diameter ( 1.5 inches) with a $\sim 1.5$ inch anode portion with a cone-shaped end in an electrolysis cell without bath.

The regular length pencil anodes were run with increasing currents until the anodes failed. The high current density was concentrated in the interior of the anode about 1 inch from the connection with the electrode rod and resulted in the anode heating to its melting temperature $\left(\sim 1650^{\circ} \mathrm{C}\right)$. The anode broke off from the connection and fell into the metal pad of the electrolysis cell without causing a thermite reaction to initiate. In general the anodes failed after the current had been elevated to 200 amps or higher. The metal and anode temperatures were increased slightly to above $1000^{\circ} \mathrm{C}$. No thermal spikes were observed when the anodes fell into the metal.

Short anodes with the cone-shaped end were run by contacting the end of the anode with the metal to obtain current and then increasing the voltage to heat the anode surface to high temperatures. The surface of the short anode heated to high temperatures to the point where the end of the anode failed by melting. Very small flashes were seen but were not repeatable when the anode was raised out of and lowered back into the metal.

Short anodes with the square cylindrical end were tested by contacting the aluminum with the flat end to complete the circuit. The voltage was increased to bring the current to 100 amps. This condition was held for several minutes and then the current was increased to 200 to 250 amps. The current density would have been $\sim 190 \mathrm{amp} / \mathrm{cm}^{2}$. The anode was monitored for its visible heat emission. The anode was plunged into the metal after the anode had reached a glowing "white" heat condition. The thermite reaction was initiated and lasted about 1 second. Inspection of the anodes tested in this manner shows that all of the cermet material was consumed in the thermite reaction. The thermocouples placed in the metal and next to the anode recorded sharp rises in temperature. In one experiment the measured metal temperature rose from 930 to $959^{\circ} \mathrm{C}$ and the anode temperature rose from $\sim 980$ to $1570^{\circ} \mathrm{C}$. The anode temperature on the surface was obviously much higher than $980^{\circ} \mathrm{C}$ as it was glowing "white" hot and is estimated to have been above $1500^{\circ} \mathrm{C}$. The amount of metal used in these experiments was 350 grams and it is estimated that the anode stub weighed $\sim 18$ grams. Experiments to set the thermite reaction off with a similar sized anode in 800 grams of metal were not successful. The mass ratios of metal to anode may be critical to initiating and sustaining the thermite reaction as the metal acts as a heat sink to the hot anode.

The larger anode shape (1.5 inch diameter by $~ 1.5$ inch length) was heated by the same procedure. Repeated attempts to get the anode hot enough to initiate a thermite reaction failed. The maximum current possible with the power supply is $\sim 600$ amps with a resulting current density of $\sim 50 \mathrm{amps} / \mathrm{cm}^{2}$.

The shorting of an anode to the metal pad was simulated. Thermite ignition temperature $\left(1400^{\circ} \mathrm{C}\right)$ was achieved in less than $20 \mathrm{~s}$ for some cases. The fuse inside the Inconel tube does not see these high and localized temperatures until at least 5 minutes (maybe more) later. 


\section{Thermite Initiation Temperatures}

Sintered inert anode powder was mixed with aluminum powder for determination of reaction temperatures by differential thermal analysis (DTA). The anode powder was generated from sintered slugs of the inert anode composition. Several screen fractions of anode powder were used with the particle size ranging from about 0.04 to $1 \mathrm{~mm}$. Approximately $35 \mathrm{mg}$ of 50/50 mixtures anode/aluminum powder combinations were heated in alumina crucibles in the DTA at $5 \mathrm{C} / \mathrm{min}$ to $1450^{\circ} \mathrm{C}$ in air.

The DTA showed a consistent endothermic peak for the melting of $\mathrm{Al}$ at $660^{\circ} \mathrm{C}$ and a major exothermic reaction that initiated at temperatures ranging from 950 to $981^{\circ} \mathrm{C}$ for the finest to the coarsest power.

In conclusion, the thermite reaction studies showed that the thermite reaction concern was not as severe as we had expected. The reaction was not self-sustaining when an anode was dropped into the molten aluminum even if the anode was quite hot. The reaction could only be sustained for longer periods if current and thus heat were maintained after the anode was lowered into the metal.

\section{Environment, Health and Safety (EHS)}

New Employee Orientation and EHS required training were provided to the new employees during the month of January.

The group decided that aluminum powder would not be used in the part formulation. This has eliminated the aluminum powder safety standards concerns.

EHS facilitated Project Environment, Health and Safety Reviews of the following operations of the R\&D activity.

- Pilot Hall Cell PEHSR

- Thermite Reaction Test Bldg. B PEHSR

A Fourier transform infrared spectrometer (FTIR) equipped with a gas cell, and a process mass spectrometer (MS) were installed next to the pilot cell, running on inert anodes, in Building $\mathrm{B}$. These instruments were used to actively monitor ambient and cell gas components (i.e., $\mathrm{HF}, \mathrm{CF}_{4}, \mathrm{C}_{2} \mathrm{~F}_{6}, \mathrm{HCl}, \mathrm{SO}_{2}, \mathrm{COS}, \mathrm{SiF}_{4}, \mathrm{CO}, \mathrm{CO}_{2}, \mathrm{O}_{2}$ ) during different periods of pot tending activity. The instrumental monitoring of the pilot cell served an additional role as a testing ground for setup, sampling and capable monitoring using FTIR, and MS.

- ATS conducted three tests using EPA Method 29 to determine total particulate and metal particulate. None of the results were higher than expected and none were a cause for concern.

- NIOSH Method 6007 was conducted to determine Nickel Carbonyl levels coming off the pilot cell exhaust. No nickel carbonyl was detected. 
Industrial Hygiene Sampling

Industrial Hygiene sampling was conducted on the Horizontal Pilot Cell. Personal and area samples both indicated very low exposures to typical Hall cell off gasses.

\section{Task 3.2 - Optimize Metal Content and Metal Phase Adders}

The thermal and electrical conductivity of a cermet anode is dramatically increased by increasing the copper metal phase from $17 \%$ to $27 \%$ of the anode weight. Based on prior results, the corrosion rate of a $27 \%$ anode can be comparable to the $17 \%$ anode but is more vulnerable to bath ratio changes and other operational variables. In addition, Alcoa proprietary data indicate that it is possible to increase the metal content by using certain other metals in addition to copper without sacrificing anode performance.

\section{Task 3.3 - Optimize Ceramic Phase, Develop Advanced Anode Compositions}

It is probable that the composition of the ceramic phase can be optimized to reduce the nickel content of the aluminum and perhaps the corrosion rate. This can be done by further optimizing the $\mathrm{Ni} / \mathrm{Fe}$ ratio in the present cermet anode. Advanced ceramic phase compositions as well as additives to the present cermet will also be considered.

The materials work on Tasks 3.2, 3.3 and 13 was completed on October 01, 1999 and reported to DOE during the program review on November 02, 1999.

The following sections 5.3-3.1 to 5.3-3.3 cover the program review material in detail. In conclusion, we met the DOE targets of $\mathrm{Fe}, \mathrm{Ni}$ and $\mathrm{Cu}$ contamination when we used $\mathrm{Ag}$ additive. The $\mathrm{Cu}$ levels in the metal were below the commercial purity level in some runs. $\mathrm{Ni}$ and Fe were not below the commercial purity level.

\section{3-3.1 Introduction}

The energy and cost efficiency of aluminum smelting can be significantly reduced with the use of long lasting non-consumable (inert) and dimensionally stable anodes. This allows highly productive cell design reducing capital costs. Significant environmental benefits also result because of no $\mathrm{CO}_{2}$ and $\mathrm{CF}_{4}$ emissions. The use of dimensionally stable anode and wettable cathode also allows efficient cell designs and lower anode-cathode distance and consequent energy savings.

The most significant challenge to the realization of this technology is the anode material. In fact, searches have continued since the early days of the Hall-Heroult process for suitable inert anode material. For the material to function as an anode, it has to satisfy a number of very difficult conditions. For example, the material must not react or dissolve to any significant extent in the electrolyte (cryolite). It must not react or corrode in oxygen 
containing atmosphere. It should be thermally stable at about $1000^{\circ} \mathrm{C}$. It must relatively inexpensive and should have sufficient mechanical strength. It must also have very high electrical conductivity (> $120 \mathrm{ohm}-1 \mathrm{~cm}-1)$ at the Hall cell operating temperature (950$970^{\circ} \mathrm{C}$ ). In addition, the aluminum produced using these anodes should not be contaminated with the constituents of the anode material to any appreciable extent.

Numerous materials have been tried in the past. Among them are the "corrosion and oxidation resistant metals and alloys', electronic and ionic conducting oxides such as $\mathrm{ZrO}_{2}$, $\mathrm{SnO}_{2}, \mathrm{Fe}_{2} \mathrm{O}_{3}, \mathrm{NiFe}_{2} \mathrm{O}_{4}, \mathrm{NiO}$, etc. Despite attempts by various researchers, the inert anode is not a commercial reality. These materials failed to satisfy one or more of the abovementioned criteria. Billehaug and Oye (1981) reviewed past efforts to develop cermet anodes. Sadoway (1993) at MIT has more recently proposed use of $\mathrm{Cu}-\mathrm{Al}$ alloys. A number of patents have also been issued to Moltech where they have used metallic alloys containing $\mathrm{Ni}, \mathrm{Fe}, \mathrm{Cu}, \mathrm{Zn}, \mathrm{Sn}$, etc. One of the difficulties of using metallic alloys is the fact that metals or alloys of this type always oxidize on the surface and it is difficult to maintain a consistently corrosion resistant surface. Ray (1986) introduced the concept of cermet anodes in which a highly corrosion and oxidation resistant ceramic oxide is combined with a compatible metal to provide anode compositions that provide the desirable mechanical and electrical properties. It was found that $17 \mathrm{w} \% \mathrm{Cu}$ metal containing $51.7 \mathrm{w} \% \mathrm{NiO}$ and 48.3 w\% $\mathrm{Fe}_{2} \mathrm{O}_{3}$ oxides fabricated as cermet provided good electrical conductivity, mechanical properties and encouraging Hall cell corrosion performance.

This anode composition has been fabricated and tested in a number of bench scale and Pilot Hall cells. Although most of the tests were carried out at about $960^{\circ} \mathrm{C}$, a number of tests were also carried out at lower $\left(840-750^{\circ} \mathrm{C}\right)$ temperatures. Bench scale tests have shown that this anode composition has shown very encouraging results under operating conditions where alumina is maintained at a level close to saturation and ratio is maintained at about 1.1. However, the metal produced using this anode composition still contained more than $0.1 \mathrm{w} \%$ $\mathrm{Cu}$. While this level of $\mathrm{Cu}$ in aluminum may still be acceptable as being usable for most applications, it is desirable to reduce the corrosion of anode for longer life and improved economics. Further, reduced corrosion should also lead to improved metal quality with respect to $\mathrm{Ni}$ and $\mathrm{Fe}$, the other two major contaminants from the anode.

We have, therefore, embarked on a two pronged approach to improving the quality of metals while using inert anodes. The first approach is to modify the composition of the alloy in the cermet to lower the $\mathrm{Cu}$ contamination and thereby also improve the corrosion resistance. The second approach is to modify the oxide part of the cermet to impart additional corrosion resistance. During this period we report results on the cermet anodes where the metal phase was modified, the oxide phase contained Nickel ferrite spinel and Nickel ferrite spinel with excess $\mathrm{NiO}$. Silver was added with the $\mathrm{Cu}$ metal to achieve this result. We also used palladium with $\mathrm{Cu}$ metal to improve corrosion resistance of cermet. We obtained some powder coated with Ag and fabricated samples with it. 


\section{3-3.2 Materials Composition and Fabrication}

The oxide phase in the present study contained $\mathrm{NiO}$ and $\mathrm{Fe}_{2} \mathrm{O}_{3}$ in the ratio of $51.7: 48.3$ (sample 5301). In addition, a number of samples containing stoichiometric Nickel ferrite, $\left(\mathrm{NiO} / \mathrm{Fe}_{2} \mathrm{O}_{3}\right.$ in the ratio of 74.7: 159.6) (samples identified as 5412) were prepared. The fabrication of cermet samples involved first the preparation of pressible oxide powder, followed by blending of the desired amount of metallic particulates. The blended powder was then pressed in a isostatic bag mold at 25,000 psi. The pressed material was then sintered in an argon/oxygen mixture at about $1350^{\circ} \mathrm{C}$. The pressible powder was prepared by blending $\mathrm{NiO}$ from Ceramic Color and Chemical Co. and $\mathrm{Fe}_{2} \mathrm{O}_{3}$ from Harcross chemicals $\mathrm{Co}$. The powders were blended and calcined to make sure the spinel phase was formed and no unreacted $\mathrm{Fe}_{2} \mathrm{O}_{3}$ remained. The calcined powder was then spray dried to produce agglomerates of about 40 micron diameter. For reliable and reproducible anode performance, it is important to characterize the samples with respect to density, porosity and microstructure of the fabricated anodes. We developed a standard operating procedure (see Appendix 1) for fabrication of the anodes. One important aspect of anode fabrication is the connection to metallic lead. For these anodes a graded connection with varying amounts of a mixture of cermet and metal ending up with purer metal end was used.

The Tables 5.3-3-1 and 5.3-3-2 show the details of fabricated anodes. 


\section{Table 5.3-3-1}

\begin{tabular}{|c|c|c|c|c|}
\hline S \# & Compositions & $\begin{array}{c}\text { Apparent } \\
\text { Porosity }\end{array}$ & & Temp. \\
\hline $776670-22$ & $83 \% 5301+17 \% \mathrm{Cu}$ & 0.192 & & $1350 \mathrm{C}$ \\
\hline $776670-33$ & $83 \% 5301+17 \% \mathrm{Cu}$ & 0.214 & & $1350 \mathrm{C}$ \\
\hline $776701-22$ & $83 \% 5412+17 \% \mathrm{Cu}$ & 0.178 & & $1350 \mathrm{C}$ \\
\hline 776673-44 & $3 \% \mathrm{Ag} 14 \% \mathrm{Cu} 83 \% 5301$ & 0.299 & & $1350 \mathrm{C}$ \\
\hline 776693-2 & $3 \% \mathrm{Ag} 14 \% \mathrm{Cu} 83 \% 5301$ & 0.249 & & $1350 \mathrm{C}$ \\
\hline 776693-4 & $3 \% \mathrm{Ag} 14 \% \mathrm{Cu} 83 \% 5301$ & 0.286 & & $1350 \mathrm{C}$ \\
\hline $776701-1$ & $83 \% 5412+17 \% \mathrm{Cu}$ & 0.182 & & $1350 \mathrm{C}$ \\
\hline $776705-3$ & $3 \% \mathrm{Ag} 14 \% \mathrm{Cu} 83 \% 5412$ & 0.292 & & $1350 \mathrm{C}$ \\
\hline $776705-4$ & $3 \% \mathrm{Ag} 14 \% \mathrm{Cu} 83 \% 5412$ & 0.276 & & $1350 \mathrm{C}$ \\
\hline $776705-2$ & $3 \% \mathrm{Ag} 14 \% \mathrm{Cu} 83 \% 5412$ & 0.243 & & $1350 \mathrm{C}$ \\
\hline $776705-1$ & $3 \% \mathrm{Ag} 14 \% \mathrm{Cu} 83 \% 5412$ & 0.215 & & $1350 \mathrm{C}$ \\
\hline $776718-1$ & $83 \% 530117 \% \mathrm{Cu}$ & 0.188 & $\mathrm{Cu}$ coated with $\mathrm{Ag}$ & $1350 \mathrm{C}$ \\
\hline $776719-1$ & $83 \% 541217 \% \mathrm{Cu}$ & 0.163 & $\mathrm{Cu}$ coated with $\mathrm{Ag}$ & $1350 \mathrm{C}$ \\
\hline $776673-26$ & $3 \% \mathrm{Ag} 14 \% \mathrm{Cu} 83 \% 5301$ & 0.284 & & $1350 \mathrm{C}$ \\
\hline $776754-1$ & $3 \% \mathrm{Ag} 14 \% \mathrm{Cu} 83 \% 5412$ & 0.166 & Ag from Technic Inc. & $1350 \mathrm{C}$ \\
\hline $776720-1$ & $5 \% 530195 \% 5412(3 \% \mathrm{Ag} 14 \% \mathrm{Cu})$ & 0.24 & & $1350 \mathrm{C}$ \\
\hline $776721-1$ & $5 \% 530195 \% 5412+17 \% \mathrm{Cu}$ & 0.248 & & $1350 \mathrm{C}$ \\
\hline $776722-1$ & $10 \% 530190 \% 5412(3 \%$ Ag $14 \% \mathrm{Cu})$ & 0.24 & & $1350 \mathrm{C}$ \\
\hline $776723-1$ & $10 \% 530190 \% 5412+17 \% \mathrm{Cu}$ & 0.196 & & $1350 \mathrm{C}$ \\
\hline 776724-1 & $20 \% 530180 \% 5412(3 \% \mathrm{Ag} 14 \% \mathrm{Cu})$ & 0.216 & & $1350 \mathrm{C}$ \\
\hline $776725-1$ & $20 \% 530180 \% 5412+17 \% \mathrm{Cu}$ & 0.157 & & $1350 \mathrm{C}$ \\
\hline $776733-1$ & $1 \% 530199 \% 5412(3 \% \mathrm{Ag} 14 \% \mathrm{Cu})$ & 0.197 & & $1350 \mathrm{C}$ \\
\hline $776734-1$ & $1 \% 530199 \% 5412+17 \% \mathrm{Cu}$ & 0.122 & & $1350 \mathrm{C}$ \\
\hline $776735-1$ & $2 \% 530198 \% 5412(3 \% \mathrm{Ag} 14 \% \mathrm{Cu})$ & 0.186 & & $1350 \mathrm{C}$ \\
\hline $776736-1$ & $2 \% 530198 \% 5412+17 \% \mathrm{Cu}$ & 0.202 & & $1350 \mathrm{C}$ \\
\hline $776737-1$ & $3 \% 530197 \% 5412(3 \% \mathrm{Ag} 14 \% \mathrm{Cu})$ & 0.237 & & $1350 \mathrm{C}$ \\
\hline $776738-1$ & $3 \% 530197 \% 5412+17 \% \mathrm{Cu}$ & 0.203 & & $1350 \mathrm{C}$ \\
\hline $776720-2$ & $5 \% 530195 \% 5412(3 \% \mathrm{Ag} 14 \% \mathrm{Cu})$ & 0.231 & & $1320 \mathrm{C}$ \\
\hline $776722-2$ & $10 \% 530190 \% 5412(3 \% \mathrm{Ag} 14 \% \mathrm{Cu})$ & 0.176 & & $1320 \mathrm{C}$ \\
\hline $776724-2$ & $20 \% 530114 \% 5412(3 \% \mathrm{Ag} 14 \% \mathrm{Cu})$ & 0.244 & & $1320 \mathrm{C}$ \\
\hline $776733-2$ & $1 \% 530199 \% 5412(3 \% \mathrm{Ag} 14 \% \mathrm{Cu})$ & 0.169 & & $1320 \mathrm{C}$ \\
\hline $776735-2$ & $2 \% 530114 \% 5412(3 \% \mathrm{Ag} 14 \% \mathrm{Cu})$ & 0.22 & & $1320 \mathrm{C}$ \\
\hline 776737-2 & $3 \% 530197 \% 5412(3 \% \mathrm{Ag} 14 \% \mathrm{Cu})$ & 0.228 & & $1320 \mathrm{C}$ \\
\hline 776739-1 & $1 \% 530199 \% 5412(1 \%$ Ag 14\% Cu) & 0.162 & & $1320 \mathrm{C}$ \\
\hline $776740-1$ & $3 \% 530197 \% 5412(1 \% \mathrm{Ag} 14 \% \mathrm{Cu})$ & 0.198 & & $1320 \mathrm{C}$ \\
\hline 776741-1 & $5 \% 530114 \% 5412(1 \% \mathrm{Ag} 14 \% \mathrm{Cu})$ & 0.123 & & $1320 \mathrm{C}$ \\
\hline
\end{tabular}


Table 5.3-3-2

Anodes with Standard 17\% Cu Cermet and Varying Quantities of Ag Powder

\begin{tabular}{|c|c|c|c|}
\hline Sample \# & Composition With 5301 & $\begin{array}{c}\text { Sintering } \\
\text { Temp C }\end{array}$ & $\begin{array}{c}\text { Apparent } \\
\text { Porosity }\end{array}$ \\
\hline $776670-1$ & $17 \% \mathrm{Cu}+83 \%$ & 1351 & 0.129 \\
\hline $776670-2$ & $17 \% \mathrm{Cu}+83 \%$ & 1345 & 0.138 \\
\hline $776670-3$ & $17 \% \mathrm{Cu}+83 \%$ & 1348 & 0.151 \\
\hline $776670-4$ & $17 \% \mathrm{Cu}+83 \%$ & 1348 & 0.299 \\
\hline $776670-5$ & $17 \% \mathrm{Cu}+83 \%$ & 1356 & 0.194 \\
\hline $776670-6$ & $17 \% \mathrm{Cu}+83 \%$ & 1367 & 0.178 \\
\hline $776670-10$ & $17 \% \mathrm{Cu}+83 \%$ & 1351 & 0.161 \\
\hline $776670-13$ & $17 \% \mathrm{Cu}+83 \%$ & 1383 & 0.257 \\
\hline $776670-14$ & $17 \% \mathrm{Cu}+83 \%$ & 1336 & 0.182 \\
\hline $776670-17$ & $17 \% \mathrm{Cu}+83 \%$ & 1342 & 0.237 \\
\hline $776670-23$ & $17 \% \mathrm{Cu}+83 \%$ & 1323 & 0.199 \\
\hline 776670-24 & $17 \% \mathrm{Cu}+83 \%$ & 1291 & 0.254 \\
\hline $776670-25$ & $17 \% \mathrm{Cu}+83 \%$ & 1350 & 0.240 \\
\hline $776670-26$ & $17 \% \mathrm{Cu}+83 \%$ & 1353 & 0.209 \\
\hline $776670-27$ & $17 \% \mathrm{Cu}+83 \%$ & 1355 & 0.286 \\
\hline $776670-28$ & $17 \% \mathrm{Cu}+83 \%$ & 1347 & 0.232 \\
\hline $776670-30$ & $17 \% \mathrm{Cu}+83 \%$ & 1342 & 0.292 \\
\hline $776670-31$ & $17 \% \mathrm{Cu}+83 \%$ & 1337 & 0.245 \\
\hline $776670-32$ & $17 \% \mathrm{Cu}+83 \%$ & 1337 & 0.220 \\
\hline $776671-1$ & $5 \% \mathrm{Ag}+10 \% \mathrm{Cu}+85 \%$ & 1350 & 0.144 \\
\hline $776671-2$ & $5 \% \mathrm{Ag}+10 \% \mathrm{Cu}+85 \%$ & 1345 & 0.283 \\
\hline $776671-3$ & $5 \% \mathrm{Ag}+10 \% \mathrm{Cu}+85 \%$ & 1318 & 0.221 \\
\hline $776673-1$ & $3 \% \mathrm{Ag}+14 \% \mathrm{Cu}+83 \%$ & 1350 & 0.213 \\
\hline $776673-3$ & $3 \% \mathrm{Ag}+14 \% \mathrm{Cu}+83 \%$ & 1350 & 0.276 \\
\hline $776673-4$ & $3 \% \mathrm{Ag}+14 \% \mathrm{Cu}+83 \%$ & 1349 & 0.204 \\
\hline $776673-5$ & $3 \% \mathrm{Ag}+14 \% \mathrm{Cu}+83 \%$ & 1338 & 0.235 \\
\hline $776673-6$ & $3 \% \mathrm{Ag}+14 \% \mathrm{Cu}+83 \%$ & 1349 & 0.224 \\
\hline 776673-7 & $3 \% \mathrm{Ag}+14 \% \mathrm{Cu}+83 \%$ & 1351 & 0.286 \\
\hline $776673-16$ & $3 \% \mathrm{Ag}+14 \% \mathrm{Cu}+83 \%$ & 1265 & 0.227 \\
\hline $776673-18$ & $3 \% \mathrm{Ag}+14 \% \mathrm{Cu}+83 \%$ & 1293 & 0.301 \\
\hline $776673-23$ & $3 \% \mathrm{Ag}+14 \% \mathrm{Cu}+83 \%$ & 1209 & 0.296 \\
\hline $776673-27$ & $3 \% \mathrm{Ag}+14 \% \mathrm{Cu}+83 \%$ & 1290 & 0.263 \\
\hline $776673-40$ & $3 \% \mathrm{Ag}+14 \% \mathrm{Cu}+83 \%$ & 1345 & 0.300 \\
\hline $776673-51$ & $3 \% \mathrm{Ag}+14 \% \mathrm{Cu}+83 \%$ & 1320 & 0.260 \\
\hline $776673-53$ & $3 \% \mathrm{Ag}+14 \% \mathrm{Cu}+83 \%$ & 1324 & 0.272 \\
\hline $776673-56$ & $3 \% \mathrm{Ag}+14 \% \mathrm{Cu}+83 \%$ & 1308 & 0.278 \\
\hline 776673-60 & $3 \% \mathrm{Ag}+14 \% \mathrm{Cu}+83 \%$ & 1313 & 0.282 \\
\hline $776673-61$ & $3 \% \mathrm{Ag}+14 \% \mathrm{Cu}+83 \%$ & 1313 & 0.295 \\
\hline $776674-1$ & $2 \% \mathrm{Ag}+14 \% \mathrm{Cu}+84 \%$ & 1348 & 0.195 \\
\hline $776674-3$ & $2 \% \mathrm{Ag}+14 \% \mathrm{Cu}+84 \%$ & 1320 & 0.214 \\
\hline $776674-4$ & $2 \% \mathrm{Ag}+14 \% \mathrm{Cu}+84 \%$ & 1307 & 0.229 \\
\hline $776674-6$ & $2 \% \mathrm{Ag}+14 \% \mathrm{Cu}+84 \%$ & 1313 & 0.252 \\
\hline $776715-1$ & $3 \% \mathrm{Ag}+11 \% \mathrm{Cu}+86 \%$ & 1314 & 0.237 \\
\hline $776715-3$ & $3 \% \mathrm{Ag}+11 \% \mathrm{Cu}+86 \%$ & 1325 & 0.144 \\
\hline $776715-4$ & $3 \% \mathrm{Ag}+11 \% \mathrm{Cu}+86 \%$ & 1322 & 0.208 \\
\hline
\end{tabular}


Table 5.3-3-2 - Continued

\begin{tabular}{|l|l|l|l|}
\hline $\mathbf{7 7 6 7 2 6 - 2}$ & $\mathbf{2 \%} \mathbf{A g}+\mathbf{1 5 \%} \mathbf{C u}+\mathbf{8 3} \%$ & 1284 & 0.280 \\
\hline $\mathbf{7 7 6 7 2 7 - 1}$ & $\mathbf{1 \%} \mathbf{A g}+\mathbf{1 6 \%} \mathbf{C u}+\mathbf{8 3 \%}$ & 1313 & 0.264 \\
\hline $\mathbf{7 7 6 7 2 8}-1$ & $\mathbf{1 \%} \mathbf{A g}+\mathbf{1 5 \%} \mathbf{C u}+\mathbf{8 4 \%}$ & 1315 & 0.248 \\
\hline $\mathbf{7 7 6 7 2 8 - 2}$ & $\mathbf{1 \%} \mathbf{A g}+\mathbf{1 5 \%} \mathbf{C u}+\mathbf{8 4 \%}$ & 1326 & 0.296 \\
\hline $\mathbf{7 7 6 7 4 5 - 1}$ & $\mathbf{0 . 5 \%} \mathbf{A g}+\mathbf{1 6 \%} \mathbf{C u}+\mathbf{8 3 . 5 \%}$ & 1334 & 0.195 \\
\hline $\mathbf{7 7 6 7 4 6 - 1}$ & $\mathbf{1 \%} \mathbf{A g}+\mathbf{1 5 \%} \mathbf{C u}+\mathbf{8 4 \%}$ & 1327 & 0.239 \\
\hline $\mathbf{7 7 6 7 5 1 - 1}$ & $\mathbf{0 . 5 \%} \mathbf{P d}+\mathbf{1 6 \%} \mathbf{C u}+\mathbf{8 3 . 5 \%}$ & 1320 & 0.170 \\
\hline $\mathbf{7 7 6 7 5 2 - 1}$ & $\mathbf{1 \%} \mathbf{P d}+\mathbf{1 5 \%} \mathbf{C u}+\mathbf{8 4 \%}$ & 1320 & 0.200 \\
\hline $\mathbf{7 7 6 7 5 3 - 1}$ & $\mathbf{3 \%} \mathbf{P d}+\mathbf{1 4 \%} \mathbf{C u}+\mathbf{8 3 \%}$ & 1329 & 0.151 \\
\hline
\end{tabular}

\section{3-3.3 Hall cell Evaluation}

A number of fabricated anodes were evaluated by bench scale Hall cell testing. The results of tests depend a great deal on the testing conditions. Our aim was to minimize the effect of testing variables and therefore get a clearer indication of the relative anode performance. We also developed a standard operating procedure for anode evaluation by bench scale Hall cell testing. The attached Figure 5.3-3-1 shows schematically the test apparatus.

The anode was tested at a current density of $0.33-0.5 \mathrm{~A} / \mathrm{cm}^{2}$. No major difference in performance was seen with these different current densities. The bath ratio was attempted to

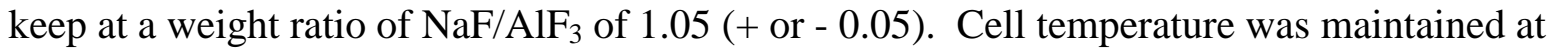
960 (+ or - 5). Alumina was fed based on at about $80-100 \%$ current efficiency values. The current efficiency was calculated based on the weight of metal produced at end of run. The current efficiency of $88-92 \%$ was obtained in many cases. The anode was measured prior to cell test and at the end of test. From these measurements, an idea of anode performance may be obtained. But we used the analyses of metal produced as the more reliable measure for anode performance.

Table 5.3-3-3 shows the results of Hall Cell tests with standard cermet anodes as well as anode with Ag element. The metal produced using these anodes are also shown in the Table 5.3-3-3. Also shown are the $1998 \mathrm{DOE}$ target amounts of impurities in the metal produced. 


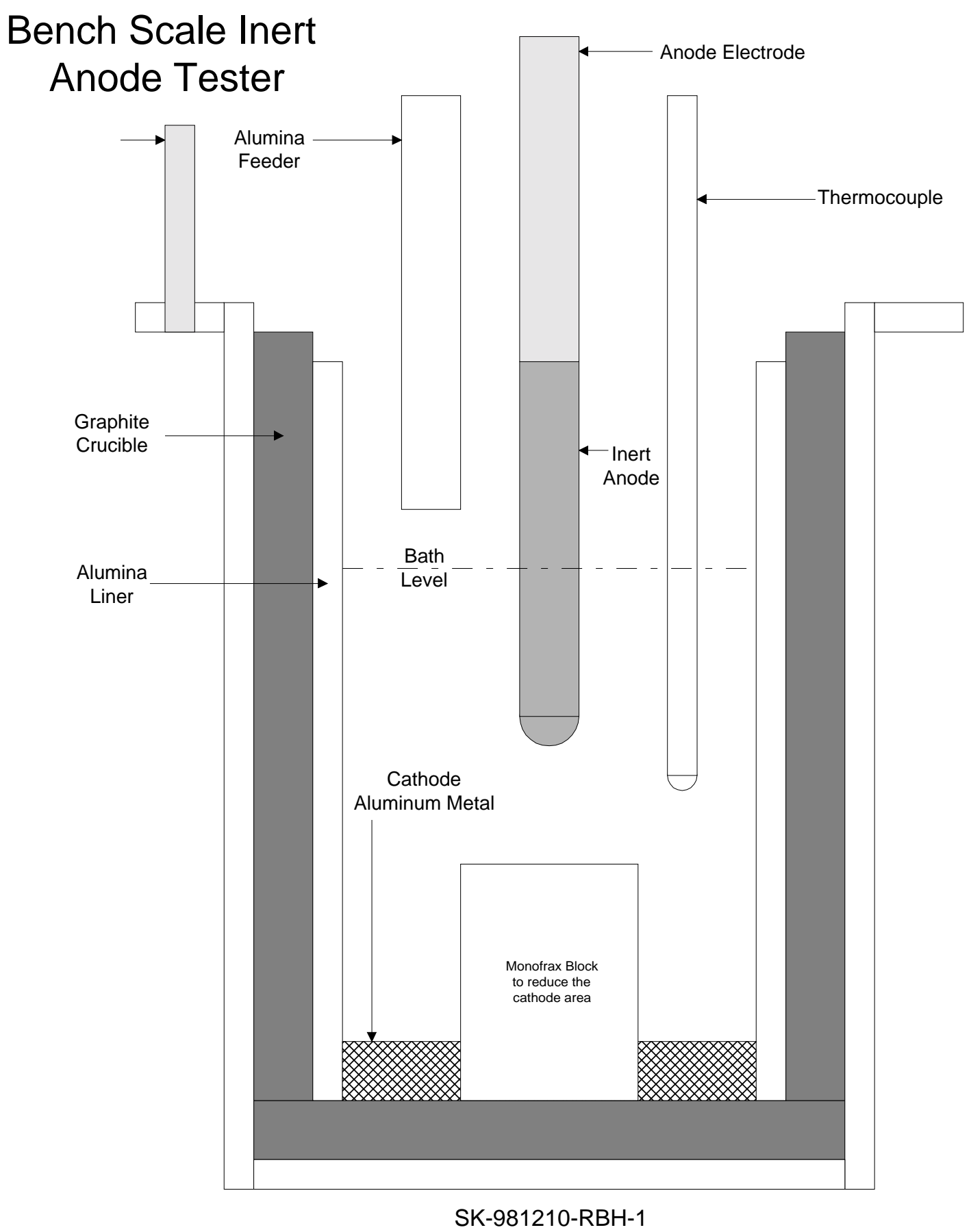

Figure 5.3-3-1 Bench Scale Hall cell Test Apparatus 


\section{Table 5.3-3-3}

$\begin{array}{lllll}\underline{\text { Anode }} & \underline{\mathrm{Fe}} & \underline{\mathrm{Cu}} & \underline{\mathrm{Ni}} & \underline{\mathrm{Ag}} \\ \text { Alcoa Standard -50 } & 0.339 & 0.222 & 1.387 & 0 \\ \text { Alcoa Standard \&Ag } & 0.459 & 0.269 & 0.22 & 0 \\ \text { Alcoa standard 100 } & 1.61 & 0.386 & 0.904 & 0 \\ 776666-2 & 0.191 & 0.024 & 0.044 & 0 \\ 776673-16 & 0.26 & 0.012 & 0.022 & 0 \\ 776705-2 & 0.375 & 0.13 & 0.1 & 0.015 \\ 776673-27 & 0.49 & 0.05 & 0.085 & 0.009 \\ 776612-1 & 0.36 & 0.034 & 0.027 & 0.004 \\ 776671-1 & 0.4 & 0.06 & 0.19 & 0.025 \\ 776719-1 & 0.38 & 0.095 & 0.12 & 0.0002 \\ 776674-3 & 0.5 & 0.13 & 0.33 & 0.02 \\ 776674-4 & 0.1 & 0.16 & 0.26 & 0.01 \\ 776715-3 & 0.14 & 0.017 & 0.13 & 0.003 \\ 776739-1 & 0.24 & 0.1 & 0.143 & 0.007 \\ 1998 \text { DOE Target } & 0.3 & 0.3 & 0.3 & 0.03\end{array}$

The Figure 5.3-3-2 shows the impurities for various anodes along with the 1998 DOE target amounts for 1998. It is seen that $\mathrm{Cu}$ impurity is significantly reduced with the addition of $\mathrm{Ag}$ element with the $\mathrm{Cu}$ phase in the cermet. Further both $\mathrm{Fe}$ and $\mathrm{Ni}$ impurities are below the target values in most case. The $\mathrm{Cu}$ content is within commercial target.

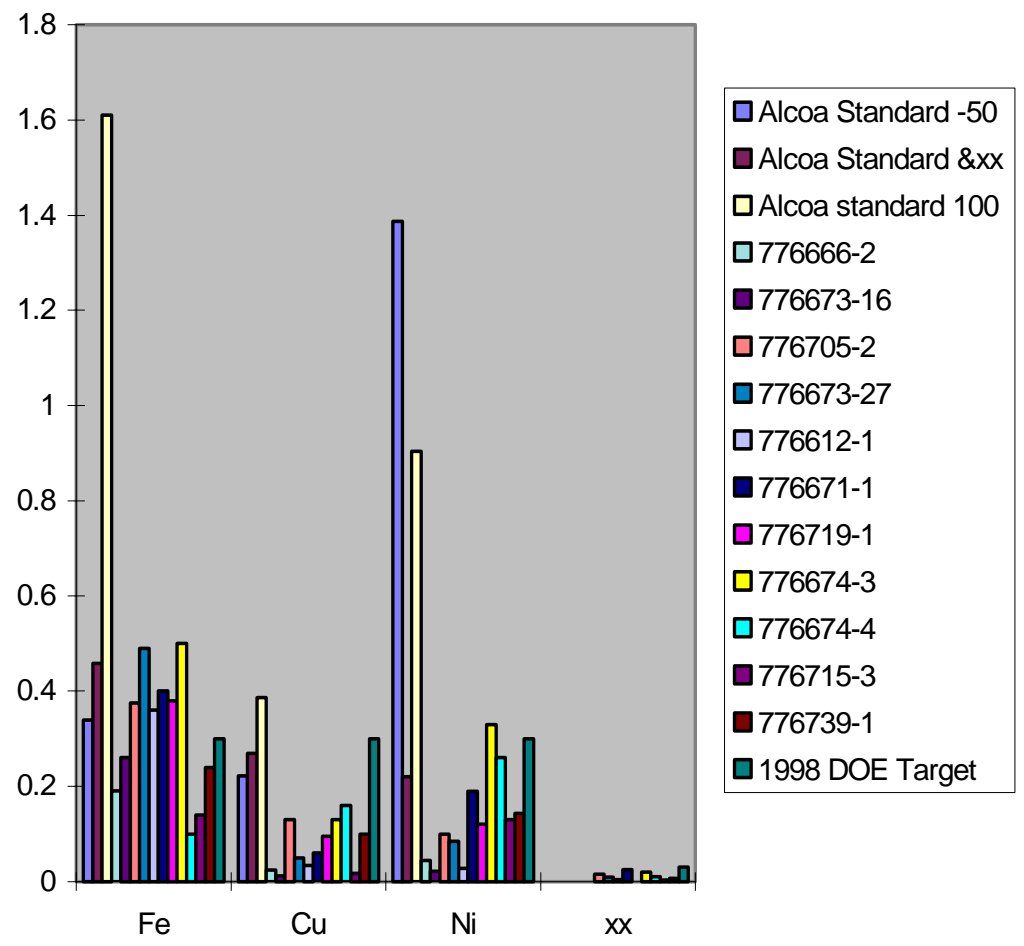

Figure 5.3-3-2 
Figures 5.3-3-5 and 5.3-3-6 show anode \# 776674-4 which is a 2\% Ag added cermet.

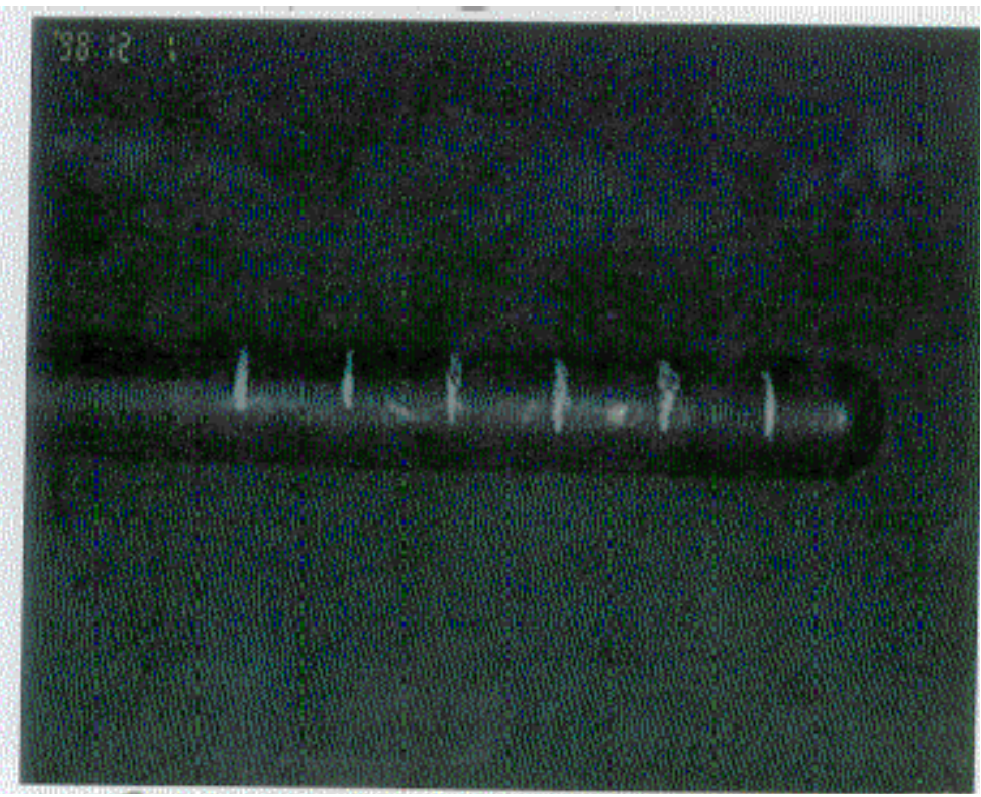

Figure 5.3-3-5: Anode 776674-4 at the start of experiment The anode contains $2 \mathrm{w} \% \mathrm{Ag}, 15 \% \mathrm{Cu}$ and balance standard Nickel ferrite cermet.

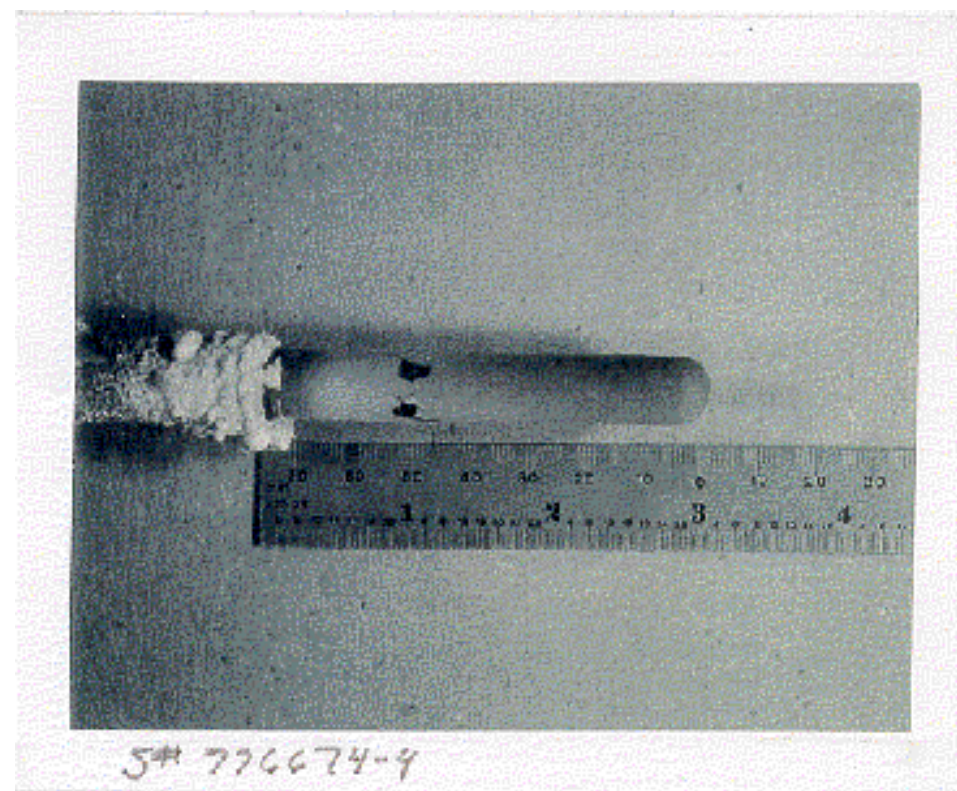

Figure 5.3-3.6 Anode 776674-4 after the experiment

The apparent corrosion at approximately 2 inches up from the right hand end of the anode is merely spalling of a white bath coating. The dark spots are merely exposed surfaces of the dark cermet anode. 
The dimensional changes in most good runs were small. The following shows the dimensional change at different levels in the anode 776674-4.

$\begin{array}{llllll}1 \mathrm{~cm} & 2 \mathrm{~cm} & 3 \mathrm{~cm} & 4 \mathrm{~cm} & 5 \mathrm{~cm} & 6 \mathrm{~cm} \\ 0.007 \mathrm{~cm} & 0.001 \mathrm{~cm} & 0.032 \mathrm{~cm} & 0.043 \mathrm{~cm} & 0.034 \mathrm{~cm} & 0.0014 \mathrm{~cm}\end{array}$

The original anode dimension was $1.18 \mathrm{~cm}$. This erosion rate represents $0.62 \mathrm{~cm} / \mathrm{year}$.

The Figure 5.3-3-4 shows that in most cases we met the DOE target of $\mathrm{Fe}, \mathrm{Ni}$ and $\mathrm{Cu}$ contamination very well when we used the $\mathrm{Ag}$ additive with the anode. Further, the $\mathrm{Cu}$ levels in the metal for all runs with these anodes were at or below the commercial purity level. The Ni and Fe were not at commercial purity level at this stage. We believe that additional materials development work will be needed to address this issue. The focus now would be integrate improved metal and oxides in the cermet.

\section{3-3.4 Summary}

The Alcoa/ DOE program which officially started in September 1998 has produced some very significantly improved results compared to what has been seen in more recent years. This was achieved because Alcoa continued to support this program throughout 1998. The results show that the target levels of metal contamination necessary for continuing on the program has been achieved.

While the DOE targets were met and while significant progress was made, the anodes tested here did not meet Alcoa's internal metal purity targets which were somewhat more stringent $(0.20 \% \mathrm{Fe}, 0.34 \% \mathrm{Ni}$ and $0.034 \% \mathrm{Cu})$. Additional development work is required.

\section{3-3.5 References}

K. Billehaug and H. A. Oye, Aluminium, 57, p. 146 (1981).

J. N. Hryn and D. R. Sadoway, Light Metals, 1993, P. 475 (1993)

S. P. Ray, Light Metals, 1986, p. 287 (1986).

\section{Acknowledgment}

The work was supported by a large number of highly qualified people.

Rob Woods, Bill Libent and Rick Krivda helped in anode preparation. Don Careatti, Dave Zebrosky, Mark Hilty, Dave Pakulsky, Ken Bailey, Ron Dunlap, Mike Slaugenhaupt, and Rich Parlett worked on Hall cell evaluation. The analytical chemistry and micostructure groups also supported this work. 


\section{Task 3.4 - Eltron Research, Inc. Anodes}

One objective of this task will be to electrochemically characterize inert anodes prepared by Eltron for aluminum electrowinning on a small laboratory scale. Corrosion rates and electrochemical behavior will be examined for each material. Several (at least three) preferred anode materials will be determined. Preferred materials will subsequently be fabricated into electrodes ( 3 of each kind) with principal dimensions of $0.5 "(1.0-1.5 \mathrm{~cm})$ diameter and 4" $(10 \mathrm{~cm})$ length for testing by Alcoa at bench scale. The anode material demonstrating most favorable characteristics and meeting Alcoa's criteria will be fabricated into plate anodes.

Over the 10 months of Task 1 of the project Eltron fabricated anodes of preferred materials in either rod or tubular form and tested these materials in melts of relevance to electrolytic aluminum reduction. In particular, several issues were addressed by Eltron: 1) Electrolyte composition, 2) materials preferred for operation in electrochemical cells with these melt compositions, 3) electrochemical cell configuration and performance issues, and 4) anode properties, including electronic conductivity, electrochemical performance, and corrosion resistance. Preferred anode materials were determined.

Electrolyte compositions chosen from the following ranges were used: cryolite $+3-8 \mathrm{wt} \%$ $\mathrm{AlF}_{3}+3-6 \mathrm{wt} \% \mathrm{CaF}_{2}+3-8 \mathrm{wt} \% \mathrm{Al}_{2} \mathrm{O}_{3}$. Typically, a melt $8 \mathrm{wt} \%$ in $\mathrm{AlF}_{3}, 4 \mathrm{wt} \%$ in $\mathrm{CaF}_{2}$, and $4 \mathrm{wt} \% \mathrm{Al}_{2} \mathrm{O}_{3}$ at $1015^{\circ} \mathrm{C}$ was employed. Materials evaluated possessed the general composition $\mathrm{Zr}_{1-\mathrm{x}-\mathrm{y}} \mathrm{Fe}_{\mathrm{x}} \mathrm{B}_{\mathrm{y}} \mathrm{O}_{2-8}$ (where $\mathrm{B}=\mathrm{Ce}, \mathrm{Ni}, \mathrm{Cu}$, and $\mathrm{Zn}$ ). Current collection was provided by an inconel wire set in a nickel paste in a well in the center of the anode. Materials were evaluated by a general protocol which consisted of immersing the anode and applying a sequence of gradually increasing currents while monitoring the anode and cathode voltages (measured with respect to a platinum wire electrode). Time dependence of voltages were monitored at a fixed current density as well. A current density of $100 \mathrm{~mA} / \mathrm{cm}^{2}$ was employed with rods and up to $515 \mathrm{~mA} / \mathrm{cm}^{2}$ with tubes. The degree of corrosion resistance was determined by visual inspection. The electrochemical performance (i.e., anode and cell voltages) and corrosion resistance were the criteria for selection of preferred materials.

It was found that tubular anodes with wall thicknesses were preferable to ceramic rod anodes in that the voltage drop across the tubular anode (due to resistance of the material) was much smaller (i.e., $<2 \mathrm{~V}$ at $500 \mathrm{~mA} / \mathrm{cm}^{2}$ versus $3 \mathrm{~V}$ at $100 \mathrm{~mA} / \mathrm{cm}^{2}$ for the rods). Electronic conductivities of up to $1 \mathrm{~S} / \mathrm{cm}$ were found. Supporting preferred metal oxide materials on alloy cylinders was attempted by pack cementation. Conductivities and electrochemical behavior of materials indicated the existence of ceramic films on the surfaces of the metal supports. However, the corrosion resistance of the metal cylinders did not seem to be significantly improved, presumably because the metal oxide layer was too thin or discontinuous. 
Seven materials were selected as viable candidates for scale-up in Task 2. The tubular geometry was determined to be the preferred geometry for these anodes. Eltron Research Inc. shipped to Alcoa tubular membranes of seven distinctive ceramic compositions: $\mathrm{c} 06$, c08, c23, c50, c51, c55, and c69. Three tubular membranes of each composition, but not necessarily of the same batch, were shipped for a total of 21 samples. $\mathrm{CeO}_{2}$ is the dominant metal oxide of compositions $\mathrm{c} 06, \mathrm{c} 08$ and $\mathrm{c} 69$, while $\mathrm{ZrO}_{2}$ is the dominant metal oxide of the other four compositions; none of the compositions includes both $\mathrm{CeO}_{2}$ and $\mathrm{ZrO}_{2}$. All seven compositions include $\mathrm{Fe}_{2} \mathrm{O}_{3}$, plus either $\mathrm{ZnO}$ or $\mathrm{NiO}$ or $\mathrm{CuO}$ or $\mathrm{SnO}_{2}$. These samples can be tested in pencil anode cells to determine wear rates and purity of aluminum produced provided adequate electrical connections can be made.

No electrolysis tests were conducted by Alcoa on the Eltron anodes.

\section{Task 3.5 - Scale-Up and Improve Manufacturing, Characterize Anodes}

Scale up of anode plates has caused cracking during sintering due to thermal stresses. Improvements in fabrication technology are required to avoid these types of problems, improve uniformity, and reduce costs.

We have successfully fabricated anodes measuring 14 inches $x 6$ inches $x 1$ inch using isostatic pressing and sintering in an argon atmosphere. Due to the long heating and cooling cycles required, a significant amount of $\mathrm{Ar}$ is consumed in the process. Furthermore, the size limitations of our existing furnace limit production to one anode at a time. We will explore the possibility of using $\mathbf{N} 2$ - air mixture for controlling the oxygen partial pressure during sintering. We will also design and build an assembly for sintering larger anodes. In order to assess the reproducibility of our process and the quality of anodes, fabricated anodes will have to be carefully characterized. This characterization will include measurements of density, porosity, electrical resistivity, microstructure and flexural strength.

Task 3.5 - Development of Thermodynamic Databases for the Dissolution of Nickel and Iron Oxides in the Cryolite Bath

\section{3-3.5.1 Statement of Problem}

Alcoa believes that an improved thermodynamic understanding of oxide, cryolite, and metal solution behavior will aid in the definition of operating windows for minimum anode wear and maximum electrolytic cell current efficiencies. Improvements to the anode composition beyond those discussed elsewhere in this study also appears to depend on realizing a better understanding of the solubility of oxides in molten cryolite. For these reasons, work was commissioned with an outside consultant to model phase equilibria in key metal oxide cryolite systems. 


\section{3-3.5.2 Approach}

Alcoa was already using the PC-base FACT thermochemical program to predict phase equilibria in other process metallurgical studies. We contacted Dr. Arthur Pelton (Centre de Recherche en Cacul Thermochimique, Ecole Polytechnique de Montreal) to develop the solution models required for the FACT themodynamic predictions. Pelton's Group follows the CALPHAD (calculated phase diagram) approach to modeling phase equilibria that has been developed and extensively applied to alloy systems. Mathematical descriptions of the Gibbs Free Energy of all phases and solutions for the chemical system are developed. In the usual procedure, descriptions of the binary systems are optimized to fit the available phase equilibria (or other thermodynamic data). These can be used to predict ternary behavior, and lack of agreement at this level is compensated for by the incorporation of ternary interaction parameters. The resulting model can be useful for ternary interpolations as well as higherorder predictions. This approach cannot be rigorously applied to the heterogeneous (oxidesalt-alloy) systems that we are interested in due the presence of solution phase miscibility gaps. More sophisticated solution treatments are therefore required. The present work focused on solid-liquid-vapor phases in the system Al-Ca-F-Fe-Na-Ni-O system. Evaluation of the thermodynamic data and development of free energy descriptions was split into two segments: 1) the solid phases and 2) the molten salt (plus liquid metal) phases. Dr. Sergei Degterov has conducted the solid phase solution modeling work. Dr. Patrice Chartrand has described the salt-metal equilibria in the Al-F-Na-Ca system and worked with Dr. Degterov to combine the two segments into the salt solubility model. All available experimental thermodynamic and salt solubility were reassessed in the course of the study. During the course of this study the FACT thermodynamic modeling approach was merged with the Chemsage approach (SOLGASMIX Gibbs energy minimizer for PC) to become FactSage.

Additional solubility measurements of $\mathrm{NiO}, \mathrm{Fe}_{2} \mathrm{O}_{3}$, and $\mathrm{NiFe}_{2} \mathrm{O}_{4}$ in cryolytic melts were conducted at Alcoa Technical Center to confirm and refine the solubility model. A static thermal equilibration method, similar to that described by DeYoung was used (Light Metals, 1986, pp.299-307). Longer equilibration times (up to $96 \mathrm{hrs)} \mathrm{were} \mathrm{used} \mathrm{and} \mathrm{the} \mathrm{bath}$ chemistry was monitored over time for solute pickup (ICP-Atomic Emission Spectrometry), bath ratio (XRD calibrated against pyrotitration), dissolved alumina (LECO technique).

Pieces of sintered oxide pellets were used in most experiments, but a few experiments were conducted with powders derived from the sintered pellets.

\section{3-3.5.3 Results}

The salt solubility experiments that were conducted in this study are summarized in Table 5.3-3.5-1.

The complete evaluation of the thermodynamic model includes an assessment of the fit of all available thermodynamic data and relevant phase diagrams. Only the fit to some of the solubility data for iron and nickel oxides will be considered here. The fit of the solubility model to the available experimental data on FeO solubility is shown in Figure 5.3-3.5-1. Only $1020^{\circ} \mathrm{C}$ data for $\mathrm{Fe}$-saturated cryolyte melts with different alumina contents are available. The model was derived by fitting the $\mathrm{FeO}$ solubility at $0 \%$ alumina and the 
eutectic temperature in the $\mathrm{Na}_{3} \mathrm{AlF}_{6}-\mathrm{FeO}$ system. The resulting model fits the data on the effect of alumina on Fe solubility well within the experimental error.

Table 5.3-3.5-1 Results of Oxide Solubility Experiments

\begin{tabular}{|c|c|c|c|c|c|c|c|c|c|c|c|}
\hline OXIDE & $\mathrm{T},{ }^{\circ} \mathrm{C}$ & EXPER. & $\begin{array}{c}\text { STARTING } \\
\text { SALT } \\
\text { MASS } \\
(\mathrm{g}) \\
\end{array}$ & $\begin{array}{c}\text { TIME } \\
\text { (hrs) }\end{array}$ & $\begin{array}{c}\mathrm{NaF}: \mathrm{AlF}_{3} \\
\text { (by wt.) }\end{array}$ & $\begin{array}{c}\mathrm{LECO} \\
\mathrm{Al}_{2} \mathrm{O}_{3} \\
\text { (wt.\%) }\end{array}$ & $\begin{array}{c}\text { SALT } \\
\text { Fe } \\
\text { (wt. } \% \text { ) }\end{array}$ & $\begin{array}{c}\text { SALT } \\
\mathrm{Ni} \\
\text { (wt.\%) }\end{array}$ & $\begin{array}{c}\text { SALT } \\
\text { DEPTH } \\
\text { (in) }\end{array}$ & $\begin{array}{c}\text { SALT } \\
\text { MASS } \\
(\mathrm{g})\end{array}$ & $\begin{array}{c}\text { SALT } \\
\mathrm{CaF}_{2} \\
\text { (wt.\%) }\end{array}$ \\
\hline $\mathrm{NiO}$ & 960 & E53 & 160 & 0 & 1.04 & 4.0 & - & - & 1.438 & 151 & (5) \\
\hline $3.0 \mathrm{~g}$ & & & & 48 & - & - & - & 0.032 & 1.250 & 124 & - \\
\hline 7 pieces & & & & 96 & 1.13 & 4.8 & - & 0.033 & 1.125 & 107 & - \\
\hline Fe2O3 & 960 & E60 & 160 & 0 & 1.06 & 4.2 & - & & 1.35 & 142 & (5) \\
\hline $2.94 \mathrm{~g}$ & & & & 48 & - & - & 0.098 & & 1.189 & 115 & - \\
\hline 8 pieces & & & & 96 & 1.13 & 4.8 & 0.096 & & 1.000 & 98 & - \\
\hline $\mathrm{NiO}$ & 1025 & E152 & 180.8 & 0 & - & - & - & $<0.001$ & 1.625 & 170 & - \\
\hline $3.0 \mathrm{~g}$ & & & & 48 & 1.65 & 13.3 & - & 0.014 & 1.125 & 104 & - \\
\hline 54 pieces & & & & 96 & 1.60 & 14.0 & - & 0.013 & 1.000 & 95 & 1.31 \\
\hline $\mathrm{Fe} 2 \mathrm{O3}$ & 1025 & E178 & 171 & 0 & - & 5.8 & 0.013 & - & 1.500 & 156 & 1.35 \\
\hline $3.0 \mathrm{~g}$ & & & & 48 & - & 6.6 & 0.213 & - & 1.125 & 107 & - \\
\hline 55 pieces & & & & 72 & 1.70 & 7.3 & 0.243 & - & 0.875 & 89 & 1.46 \\
\hline $\mathrm{NiO}$ & 960 & E200 & 161.6 & 0 & 1.06 & 4.8 & - & $<0.001$ & 1.500 & 158 & (5) \\
\hline $4.82 \mathrm{~g}$ & & & & 48 & 1.10 & 5.1 & - & 0.019 & 1.125 & 107 & - \\
\hline 1 piece $*$ & & & & 96 & 1.15 & 5.5 & - & 0.017 & 0.750 & 82 & - \\
\hline $\mathrm{NiO}$ & 960 & E202 & 161.6 & 0 & 1.07 & 5.0 & - & $<0.001$ & 1.500 & 158 & (5) \\
\hline $4.875 \mathrm{~g}$ & & & & 48 & 1.10 & 5.4 & - & 0.020 & 1.125 & 107 & - \\
\hline 1 piece** & & & & 96 & 1.16 & 6.0 & - & 0.016 & 1.000 & 98 & - \\
\hline
\end{tabular}


Table 5.3-3.5-1 (Continued)

\begin{tabular}{|c|c|c|c|c|c|c|c|c|c|c|c|c|}
\hline OXIDE & $\mathrm{T},{ }^{\circ} \mathrm{C}$ & EXPER. & $\begin{array}{c}\text { STARTING } \\
\text { SALT } \\
\text { MASS } \\
(\mathrm{g})\end{array}$ & $\begin{array}{c}\text { TIME } \\
(\mathrm{hrs})\end{array}$ & $\begin{array}{c}\text { NaF:AlF } \\
3 \\
\text { (by wt.) }\end{array}$ & $\begin{array}{l}\mathrm{LECO} \\
\mathrm{Al}_{2} \mathrm{O}_{3} \\
\text { (wt.\%) }\end{array}$ & $\begin{array}{c}\text { SALT } \\
\text { Fe } \\
\text { (wt. } \% \text { ) }\end{array}$ & $\begin{array}{c}\text { SALT } \\
\mathrm{Ni} \\
\text { (wt.\%) }\end{array}$ & $\begin{array}{c}\text { SALT } \\
\text { DEPTH } \\
\text { (in) }\end{array}$ & $\begin{array}{c}\text { CALC. } \\
\text { SALT } \\
\text { MASS } \\
(\mathrm{g})\end{array}$ & $\begin{array}{c}\text { SAMPLE } \\
\text { REMOVED } \\
(\mathrm{g})\end{array}$ & $\begin{array}{l}\text { SALT } \\
\text { CaF2 } \\
\text { (wt.\%) } \\
\end{array}$ \\
\hline $\begin{array}{l}\mathrm{NiFe}_{\mathbf{2}} \mathbf{O}_{\mathbf{4}} \\
0.5 \mathrm{~g} \\
\text { powder }\end{array}$ & 960 & E68 & 160 & $\begin{array}{c}0 \\
1 \\
7 \\
18 \\
24\end{array}$ & $\begin{array}{c}1.06 \\
- \\
- \\
- \\
1.09\end{array}$ & $\begin{array}{c}4.2 \\
- \\
- \\
- \\
5.1\end{array}$ & $\begin{array}{c}- \\
0.052 \\
0.064 \\
0.063 \\
0.063\end{array}$ & $\begin{array}{c}- \\
0.008 \\
0.009 \\
0.008 \\
0.008\end{array}$ & $\begin{array}{c}1.375 \\
0.75 \\
0.625 \\
- \\
0.5\end{array}$ & $\begin{array}{c}143 \\
82 \\
- \\
- \\
-\end{array}$ & & (5) \\
\hline $\begin{array}{l}\mathrm{NiFe}_{2} \mathbf{O}_{4} \\
3.1 \mathrm{~g} \\
6 \text { pieces }\end{array}$ & 960 & E44 & 160 & $\begin{array}{c}0 \\
1 \\
7 \\
24 \\
48 \\
72 \\
96 \\
\end{array}$ & 1.12 & 3.9 & $\begin{array}{c}- \\
0.025 \\
0.040 \\
0.046 \\
0.051 \\
0.051 \\
0.054 \\
\end{array}$ & $\begin{array}{c}- \\
<0.004 \\
0.007 \\
0.009 \\
0.010 \\
0.009 \\
0.009 \\
\end{array}$ & $\begin{array}{l}1.375 \\
1.375 \\
1.313 \\
1.250 \\
1.125 \\
1.063 \\
1.000 \\
\end{array}$ & \begin{tabular}{c|}
143 \\
143 \\
134 \\
124 \\
107 \\
103 \\
98 \\
\end{tabular} & $\begin{array}{c}3.47 \\
1.46 \\
0.94 \\
1.42 \\
1.05 \\
1.07 \\
3.5 \\
\end{array}$ & (5) \\
\hline $\begin{array}{l}\mathrm{NiFe}_{2} \mathrm{O}_{4} \\
9.911 \mathrm{~g} \\
1 \text { piece }\end{array}$ & 960 & E183 & 160 & $\begin{array}{c}0 \\
1 \\
7 \\
24 \\
48 \\
72 \\
96\end{array}$ & 1.20 & 5.1 & $\begin{array}{l}0.013 \\
0.030 \\
0.048 \\
0.051 \\
0.058 \\
0.061 \\
0.066\end{array}$ & $\begin{array}{c}<0.001 \\
0.006 \\
0.009 \\
0.007 \\
0.006 \\
0.006 \\
0.005\end{array}$ & $\begin{array}{l}1.500 \\
1.500 \\
1.500 \\
1.313 \\
1.125 \\
0.875 \\
0.625\end{array}$ & $\begin{array}{c}158 \\
158 \\
158 \\
134 \\
107 \\
90 \\
-\end{array}$ & $\begin{array}{l}6.6 \\
2.8 \\
2.5 \\
2.0 \\
2.0 \\
1.8 \\
9.8\end{array}$ & (5) \\
\hline
\end{tabular}

E68: powder used is 52 mole $\% \mathrm{Fe}_{2} \mathrm{O}_{3}-48$ mole $\% \mathrm{NiO}, \mathrm{D}_{50}=39.2$ microns

E44: 50.4 mole $\% \mathrm{Fe}_{2} \mathrm{O}_{3}-49.6$ mole $\% \mathrm{NiO}$ powder pressed at $20 \mathrm{ksi}$ and sintered for 4 hrs at $1350^{\circ} \mathrm{C}$ in argon - broken into pieces

E183: 50.4 mole $\% \mathrm{Fe}_{2} \mathrm{O}_{3}-49.6$ mole $\% \mathrm{NiO}$ powder pressed at $20 \mathrm{ksi}$ and sintered for $4 \mathrm{hrs}$ at $1325^{\circ} \mathrm{C}$ in argon

density of salt used in salt mass calculation $=2.06 \mathrm{~g} / \mathrm{cm}^{2}$ at $960^{\circ} \mathrm{C}$ 
Table 5.3-3.5-1 (Continued)

\begin{tabular}{|c|c|c|c|c|c|c|c|c|c|c|c|c|}
\hline OXIDE & $\mathrm{T},{ }^{\circ} \mathrm{C}$ & EXPER. & $\begin{array}{c}\text { STARTING } \\
\text { SALT } \\
\text { MASS } \\
(\mathrm{g})\end{array}$ & $\begin{array}{l}\text { TIME } \\
\text { (hrs) }\end{array}$ & $\begin{array}{c}\mathrm{NaF}: \mathrm{AlF}_{3} \\
\text { (by wt.) }\end{array}$ & $\begin{array}{l}\mathrm{LECO} \\
\mathrm{Al}_{2} \mathrm{O}_{3} \\
\text { (wt. } \% \text { ) }\end{array}$ & $\begin{array}{c}\text { SALT } \\
\text { Fe } \\
\text { (wt. } \% \text { ) }\end{array}$ & $\begin{array}{c}\text { SALT } \\
\mathrm{Ni} \\
(\mathrm{wt} \%)\end{array}$ & $\begin{array}{l}\text { SALT } \\
\text { DEPTH } \\
\text { (in) }\end{array}$ & $\begin{array}{l}\text { CALC. } \\
\text { SALT } \\
\text { MASS } \\
(\mathrm{g})\end{array}$ & $\begin{array}{c}\text { SAMPLE } \\
\text { REMOVED } \\
(\mathrm{g})\end{array}$ & $\begin{array}{c}\text { SALT } \\
\text { CaF2 } \\
\text { (wt. } \% \text { ) }\end{array}$ \\
\hline $\begin{array}{l}\mathbf{N i A l}_{2} \mathbf{O}_{4} \\
5.927 \mathrm{~g} \\
\text { sintered } \\
\text { pellet }\end{array}$ & 960 & E206 & 161.6 & $\begin{array}{c}0 \\
1 \\
7 \\
24 \\
48 \\
72 \\
96 \\
\end{array}$ & $\begin{array}{c}1.02 \\
- \\
- \\
- \\
1.11 \\
- \\
1.18 \\
\end{array}$ & $\begin{array}{c}4.0 \\
- \\
- \\
- \\
5.4 \\
- \\
6.2\end{array}$ & $\begin{array}{l}- \\
- \\
- \\
- \\
- \\
- \\
-\end{array}$ & $\begin{array}{c}<0.001 \\
0.009 \\
0.021 \\
0.023 \\
0.022 \\
0.020 \\
0.016 \\
\end{array}$ & $\begin{array}{l}1.250 \\
1.250 \\
1.250 \\
1.125 \\
1.063 \\
1.000 \\
0.875 \\
\end{array}$ & $\begin{array}{l}- \\
- \\
- \\
- \\
- \\
- \\
-\end{array}$ & $\begin{array}{l}8.3 \\
1.5 \\
1.9 \\
1.9 \\
5.9 \\
2.8 \\
5.5\end{array}$ & (5) \\
\hline $\begin{array}{l}\text { NiO } \\
4.757 \mathrm{~g} \\
1 \text { piece }\end{array}$ & 960 & E208 & 158.41 & $\begin{array}{c}0 \\
1 \\
7 \\
24 \\
48 \\
72 \\
96 \\
\end{array}$ & $\begin{array}{c}1.05 \\
- \\
- \\
- \\
1.14 \\
1.18 \\
1.20 \\
\end{array}$ & $\begin{array}{c}3.3 \\
- \\
- \\
- \\
4.3 \\
4.5 \\
4.8 \\
\end{array}$ & $\begin{array}{l}- \\
- \\
- \\
- \\
- \\
- \\
-\end{array}$ & $\begin{array}{c}<0.001 \\
0.012 \\
0.044 \\
0.055 \\
0.037 \\
0.045 \\
0.038 \\
\end{array}$ & $\begin{array}{l}1.563 \\
1.563 \\
1.563 \\
1.375 \\
1.250 \\
1.063 \\
0.750 \\
\end{array}$ & $\begin{array}{c}164 \\
164 \\
164 \\
142 \\
124 \\
103 \\
82 \\
\end{array}$ & $\begin{array}{l}6.93 \\
3.69 \\
2.26 \\
2.07 \\
5.50 \\
2.12 \\
5.67 \\
\end{array}$ & (5) \\
\hline $\begin{array}{l}\mathbf{N i O} \\
4.811 \mathrm{~g} \\
1 \text { piece }\end{array}$ & 960 & E209 & $\begin{array}{c}166.4 \\
\text { alumina } \\
\text { crucible }\end{array}$ & $\begin{array}{c}0 \\
1 \\
7 \\
24 \\
48\end{array}$ & $\begin{array}{c}1.07 \\
- \\
- \\
- \\
1.13\end{array}$ & $\begin{array}{c}8.5 \\
- \\
- \\
- \\
14.0\end{array}$ & $\begin{array}{l}- \\
- \\
- \\
-\end{array}$ & $\begin{array}{c}<0.001 \\
0.001 \\
0.0035 \\
0.0055 \\
0.005\end{array}$ & $\begin{array}{c}1.750 \\
1.750 \\
1.750 \\
1.000 \\
0.375 *\end{array}$ & $\begin{array}{l}- \\
- \\
- \\
-\end{array}$ & $\begin{array}{l}7.60 \\
1.30 \\
1.70 \\
2.00 \\
-\end{array}$ & (5) \\
\hline
\end{tabular}

E209: NiO pellet pressed at $20 \mathrm{ksi}$ and fired in air at $1350^{\circ} \mathrm{C}$ for $4 \mathrm{hrs}, 0.412$ in. diam., 0.376 in. L, * loss bath due to attack of alumina crucible

E208: $\mathrm{NiO}$ pellet pressed at $20 \mathrm{ksi}$ and fired in air at $1350^{\circ} \mathrm{C}$ for $4 \mathrm{hrs}, 0.413 \mathrm{in}$. diam., $0.368 \mathrm{in}$. $\mathrm{L}$

E206: $\mathrm{NiAl} 2 \mathrm{O} 4$ powder pressed at $20 \mathrm{ksi}$ and sintered for $4 \mathrm{hrs}$ at $1500^{\circ} \mathrm{C}$ in air $-60.2 \%$ of theoretical density, XRD shows some unreacted $\mathrm{NiO}$ and $\mathrm{Al} 2 \mathrm{O} 3$, sintered pellet was $16.5 \mathrm{~mm} \mathrm{~L}$ and $12.5 \mathrm{~mm}$ diam. but had disintegrated to pile of powder by end of experiment 


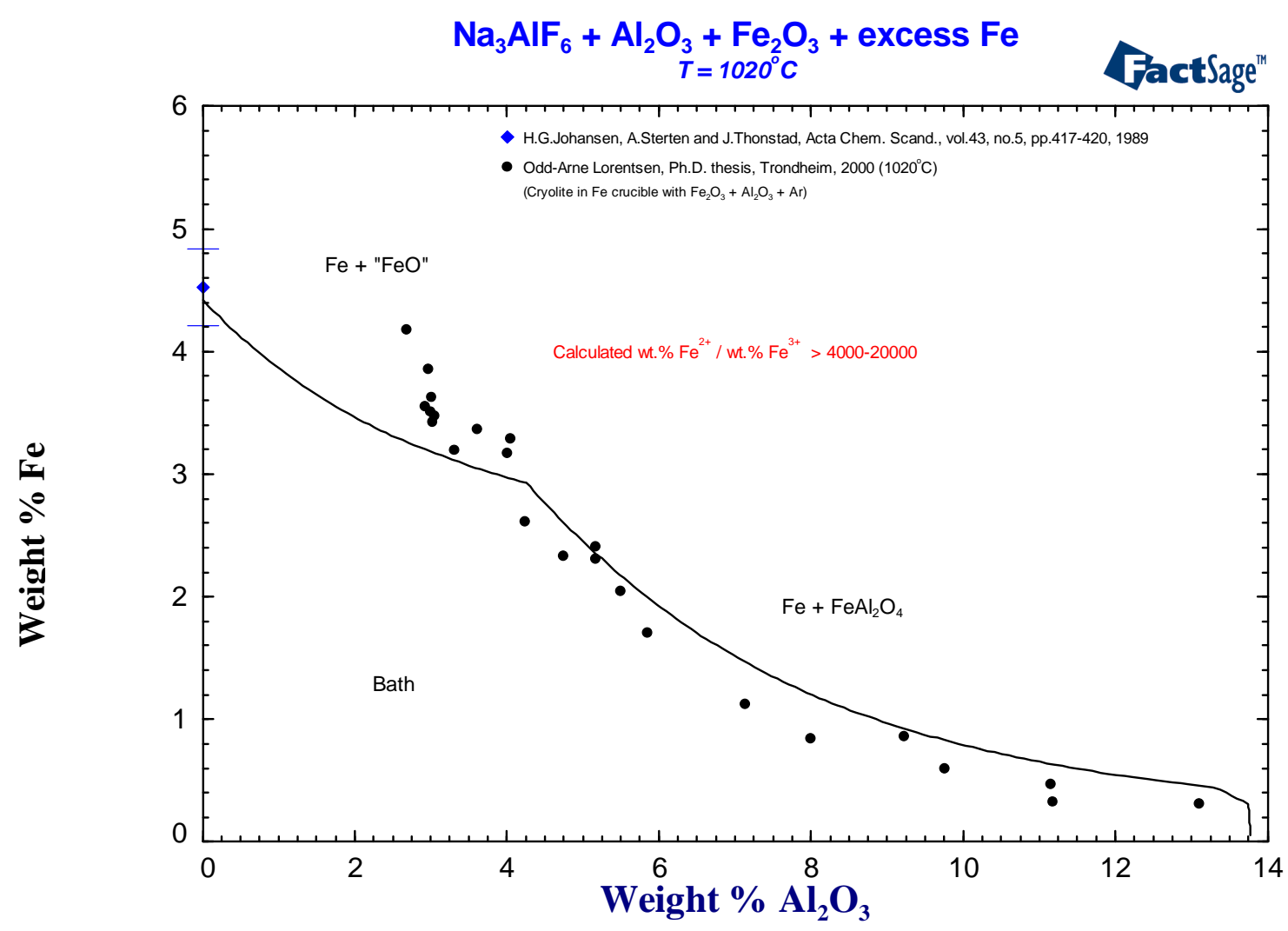

Figure 5.3-3.5-1 The predicted solubility of $\mathrm{FeO}$ in cryolite

A similar assessment of the model for $\mathrm{Fe}_{2} \mathrm{O}_{3}$ solubility is presented in Figure 5.3-3.5-2. Data in $1 \mathrm{~atm} \mathrm{O}_{2}$ and air are available and the model incorporates the equilibrium oxygen activity. There is good agreement to the solid line model predictions for most of these data (for $\mathrm{CaF}_{2}$ contents less than 3 wt.\%) at different temperatures, bath ratios, and alumina contents. The exception is the departure of the DeYoung data from the predictions at low alumina contents. An example of the fit to the temperature dependency of the DeYoung data in salts with higher alumina contents is shown in Figure 5.3-3.5-3.

An example of the model predictions for Ni solubility is shown in Figure 5.3-3.5-4. There is a very large spread in the data at $0 \%$ alumina, but the model fits well elsewhere. The model also fits data for lower temperature baths with a range of $\mathrm{CaF}_{2}$ contents. There is a larger scatter in the available data on Ni solubility between authors and within a given author's data set. Part of this may be due to the reaction path from $\mathrm{NiO}$ to the equilibrium $\mathrm{NiAl}_{2} \mathrm{O} 4$ phase. The relative amounts of solute and solvent, and the form of the solute could affect the extent of reaction and the change in bath composition during a solubility experiment. Since these details are not available for previously published work, additional experiments are required to better define the system. 


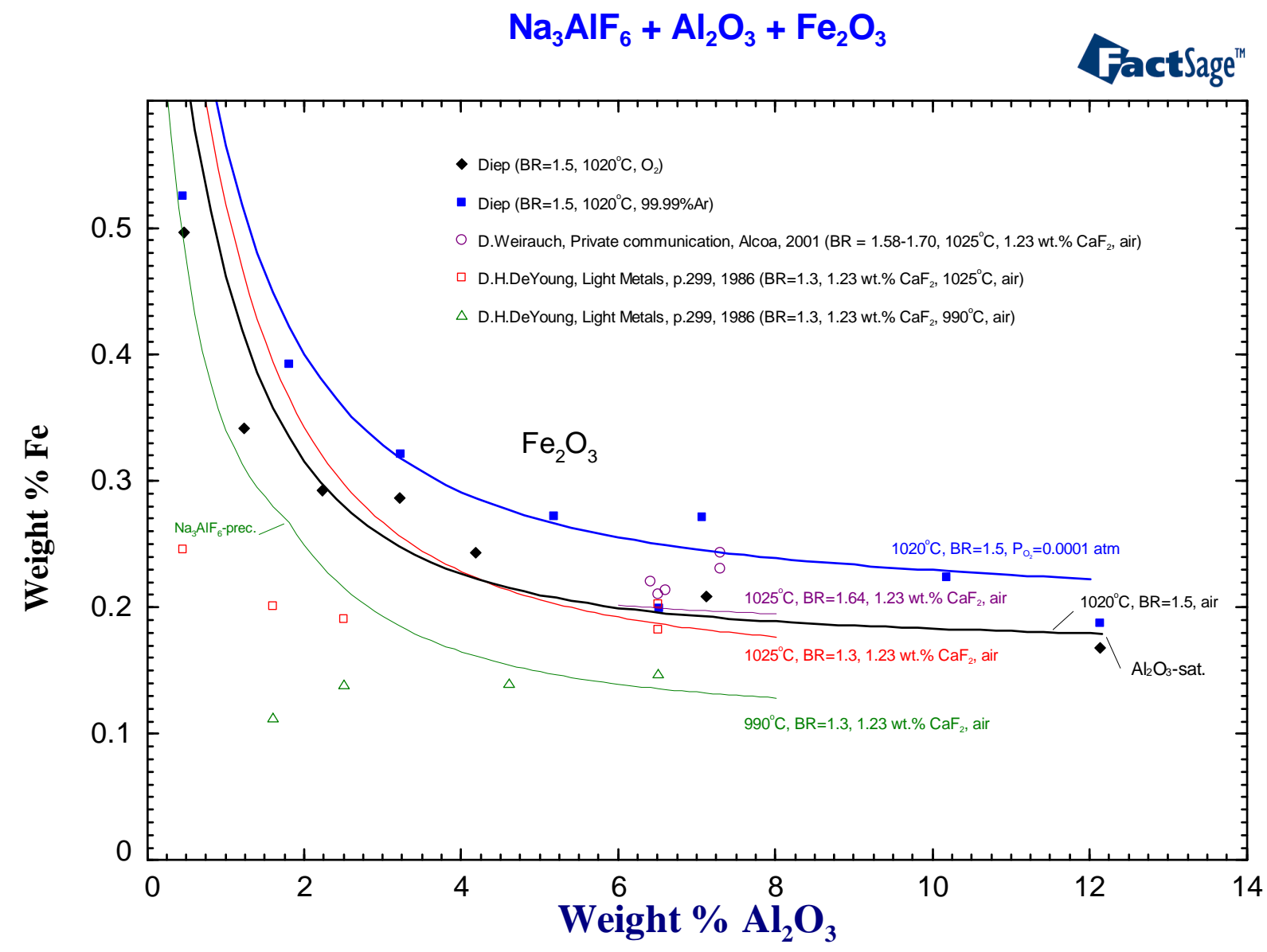

Figure 5.3-3.5-2 The predicted solubility of $\mathrm{Fe}_{2} \mathrm{O}_{3}$ in cryolitic melts. 


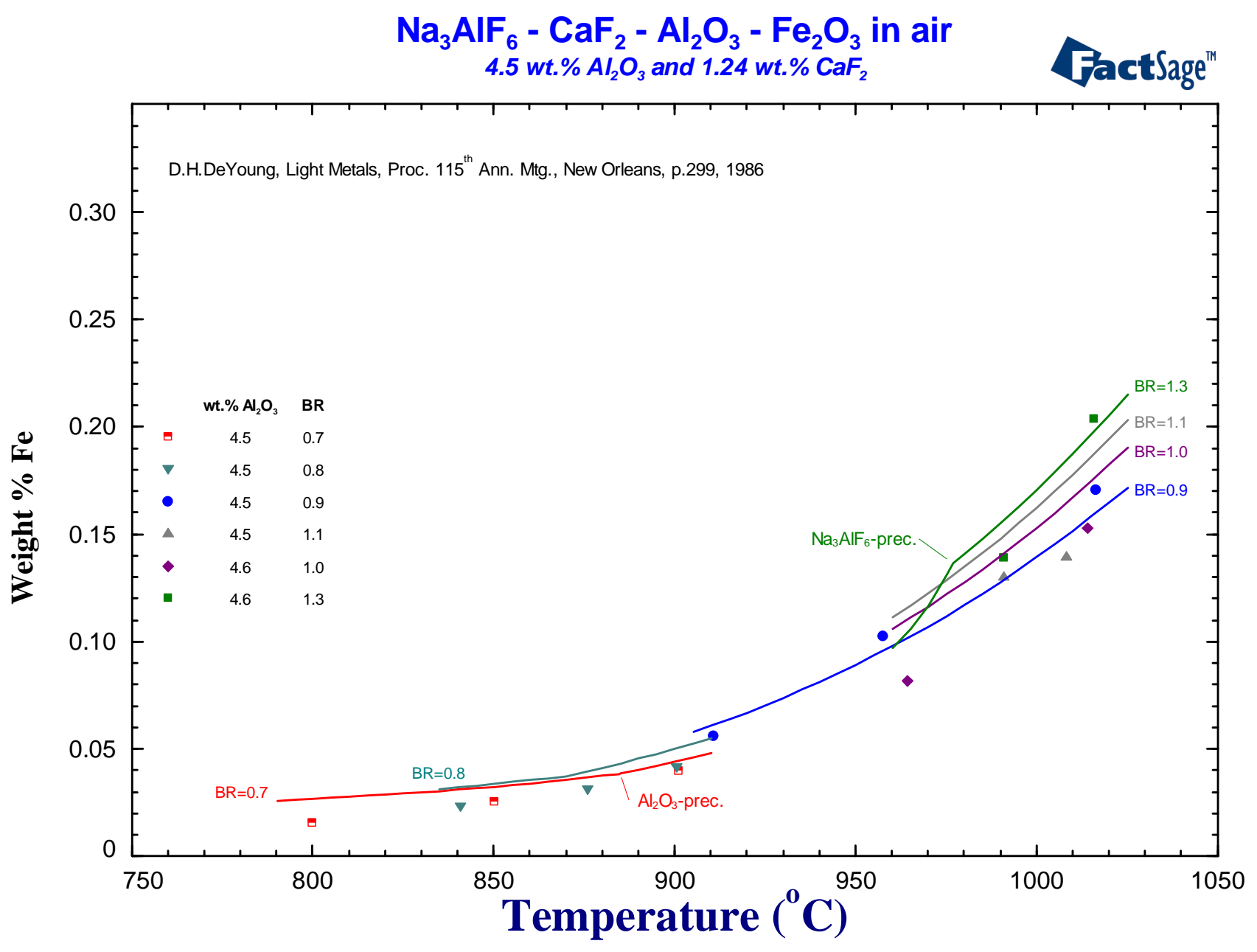

Figure 5.3-3.5-3 The predicted temperature dependency of the solubility of $\mathrm{Fe}_{2} \mathrm{O}_{3}$ in cryolitic melts. 


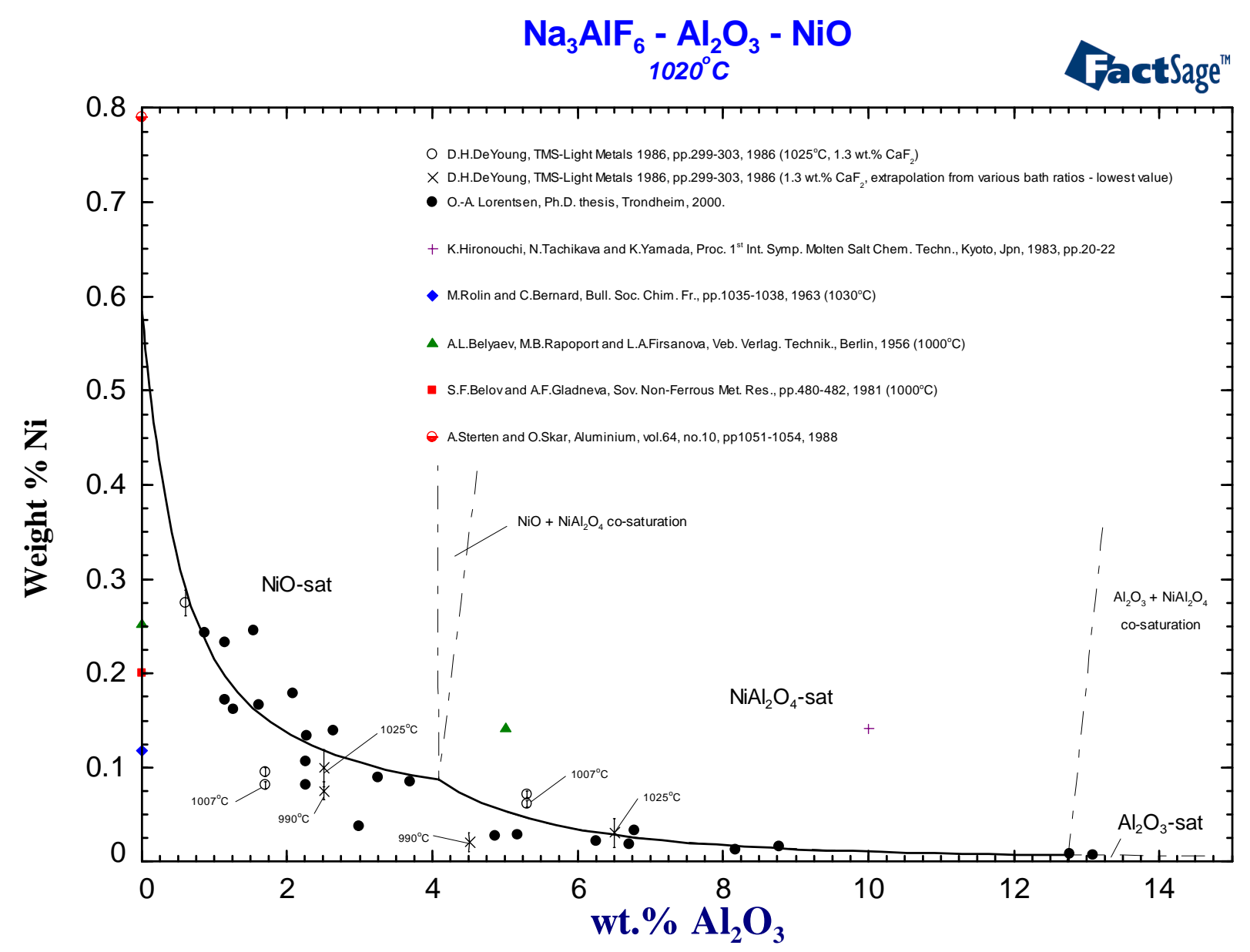

Figure 5.3-3.5-4 The predicted solubility of $\mathrm{NiO}$ in cryolitic melts

A situation similar to $\mathrm{NiO}$ exists for the interpretation of $\mathrm{NiFe}_{2} \mathrm{O}_{4}$ solubility experiments. When these results are viewed as kinetically constrained, the thermodynamic model predictions are in general good agreement with the published data of DeYoung and the new experimental data generated in this study. Again, the predicted Ni and Fe solubilities are higher than measured by DeYoung when the salt alumina content is low. Additional experiments are required.

\section{3-3.5.4 Conclusions}

A good model of $\mathrm{FeO}, \mathrm{Fe}_{2} \mathrm{O}_{3}, \mathrm{NiO}$, and $\mathrm{NiFe}_{2} \mathrm{O}_{4}$ solubility as a function of bath temperature and chemistry (bath ratio, alumina content) has been developed. Experimental results for solids that react to form a new equilibrium phase (e.g., $\mathrm{NiO}$ reacts to form $\mathrm{NiAl}_{2} \mathrm{O}_{4}$ if the alumina content is high enough) can now be properly interpreted. Previously reported solubility measurements yielded conflicting results (at least in part) since different relative amounts of reactants (solute to be measured and salt) and the form of the solute (powder or sintered pellets with variable porosity) differed. This interrupted the reaction process at whatever stage had been reached when the test was terminated. The results of solubility tests 
also differed due to the presence of different levels of salt impurities ( $\mathrm{Si}, \mathrm{Ca}$, transition metals). Finally, the composition (especially alumina and bath ratio) changes during a solubility test and has an effect on the solution behavior. Bath composition changes due to volatilization and impurity levels are generally not measured or reported in published solubility studies.

The model should be extended in the future to include other oxides. It can be linked with other chemical engineering software to perform kinetic simulations of the dissolution of ferrite-based anodes in cryolitic melts.

\section{3-3.5.5 References}

S. F. Belov, and A. F. Gladneva, Sov. Non-Ferrous Met. Res., pp. 480-482, 1981.

A. I. Belyaev, M. B. Rapoport and L. A. Firsanova, Elektrometallurgiya Alyuminiya, Metallurgizdat, Moscow, 1953.

D. H. DeYoung, Solubilities of Oxides for Inert Anodes in Cryolite-based Melts, Light Metals 1986, pp. 299-307, TMS, Warrendale, PA, 1986.

Q. B. Diep, Structure and Thermodynamics of Cryolite-based Melts with Additions of $\mathrm{Al}_{2} \mathrm{O}_{3}$ and $\mathrm{Fe}_{2} \mathrm{O}_{3}$, Ph.D. Thesis, University of Trondheim, 1998.

K. Horinouchi, N .Tachikawa, and K. Yamada, DSA in Aluminum Reduction Cells, Proc. First Int. Symp. on Molten Sallt Chemistry and Technol., Kyoto, Japan, April 20-22, 1983.

H. G. Johansen, A. Sterten, and J. Thonstad, Acta Chem. Scand., Vol. 43, No.5, pp. 417-420, 1989.

O-A Lorentsen, PhD Thesis, Dept. Electrochemistry, Norwegian Institute of Technology, Trondheim, Norway, 2000.

M. Rolin and C. Bernard, Solubilitie' des oxydes dans la cryolithe fondue, Bull. Soc. Chim. France, 1035-1038, 1963.

A. Sterten and O. Skar, Some Binary $\mathrm{Na}_{3} \mathrm{AlF}_{6}-\mathrm{M}_{\mathrm{x}} \mathrm{O}_{\mathrm{y}}$ Phase Diagrams, Aluminium 64 (10):1051-4, 1988.

\section{Task 3.6 - Build Pilot Anode Assemblies}

This sub-task includes wire cutting of the anodes, reducing a portion of the anodes, welding of anode connectors to the anodes, machining of metal plates and connectors, and final assembly of the anode modules. 
Anode Manufacturing:

Several new electrical connection concepts which would eliminate the need for postreduction and diffusion welding were tested on small scale anodes. The concepts involved green machining holes into the pressed anodes and installing nickel stubs surrounded by copper foil, copper powder or $\mathrm{Cu}$-Ni powder as a brazing material. The hope was that a hightemperature, brazed connection would be established during the sintering process itself. If successful, the process would have significantly reduced the time and processing cost of anode manufacture. Unfortunately, cracks developed in the anodes emanating out from the metal inserts.

We did not use the $27 \% \mathrm{Cu}$ composition due to concerns about excessive corrosion under the selected bath operating conditions. The anodes used in the horizontal pilot cell were made of $17 \% \mathrm{Cu}, 83 \%$ ceramic as described in Table 5.3-3-2.

Anode production for the horizontal anode pilot run progressed on schedule. Anode production was increased to four at a time with the use of a larger Inconel containment chamber for sintering. A new anode connection concept was developed which eliminated the need for surface reduction and diffusion welding, and greatly reduced processing time. The concept, which utilized a spring-loaded mechanical connection, was successfully demonstrated in a 95 hour bench scale run. This concept was used on the pilot anodes, however, diffusion welding was still done on the first set going into the cell. Two spare anodes were produced without diffusion welding. A single anode with the improved ferrite composition was also produced for the pilot run. Additional connection concepts, such as brazed connections, friction welding, metallic inserts, etc. were also explored.

Seven anodes were produced for the horizontal anode pilot run. This included four for initial installation and three backups. Two pairs of anodes tested two types of sloped gas-channels to aid in oxygen removal. The assemblies included both a diffusion welded electrical connection and a spring-loaded mechanical attachment. Two additional spares were produced with only the pressed-fit electrical connection (as per the bench scale tests), which were tested later in the run. Operational results are reported under Task 11.2

\section{TASK 5: DEVELOPMENT OF ADVANCED CATHODES AND SCALE UP}

It is desirable to make longer and taller cathodes to gain productivity. Reducing the thickness to as low as $1 / 8$ inch will reduce the cost of $\mathbf{T i B}_{2}$ without significantly increasing cell voltage or energy usage, provided the plate heights are reasonable. The requirements for obtaining these benefits include minimizing the cost of manufacturing thin plates and maintaining reasonable mechanical integrity. Preliminary results from the pilot test indicate that Alcoa's cement and/or the $\mathbf{T i B}_{2}-\mathrm{G}$ may not have been adequately wetted by molten aluminum. It is also possible, that during heat up of the cell, these materials could have been partially oxidized. These oxides could have 
contributed to the initial low equilibrium potential, sludging and inadequate cathode drainage. Advanced cathode development must also test the cathode wetting characteristics and resistance to oxide formation. Methods of protecting cathode materials must be incorporated into the cell startup procedures.

\subsection{Cost-Effective Cathode Development}

Economic evaluation of the energy-efficient cell has indicated that cost-effective cathode material is essential for industrial implementation of this technology. Available materials have suffered from either lack of performance in service or not satisfying the cost criteria. Alcoa has a patented technology for producing $\mathrm{TiB} 2-\mathrm{Al}_{2} \mathrm{O}_{3}$ and $\mathrm{ZrB}_{2-}$ $\mathrm{Al}_{2} \mathrm{O}_{3}$ composites as cost-effective cathode materials. However, this processing technique will have to be further refined, and a development program to scale up is needed. The optimum cathode composition for scale up will have to be identified.

\section{3-5.4.1. Background}

The advantages of incorporating $\mathrm{TiB}_{2}$ in cathodes have been recognized for many years. In the 1950's British Aluminum covered conventional carbon cathodes with dense $\mathrm{TiB}_{2}$ tiles to protect against erosion and wear. Its relatively good electrical conductivity, chemical stability in molten aluminum, wear resistance and its characteristic ability to be wetted by liquid aluminum makes it a very attractive cathode component. Early price and fabrication methods were prohibitive but when the new carbothermic methods of producing $\mathrm{TiB}_{2}$ powder became available, this constraint was somewhat obviated. The ability of $\mathrm{TiB}_{2}$ to be wetted by liquid aluminum allows the formation of a thin adherent film on the surface of the cathode block not possible on conventional carbon cathodes since they are not wetted by molten aluminum. The thin adherent film provides for the reduction of the thickness of the aluminum pad required to maintain the interfacial stability of the electrolyte bath and the liquid aluminum. This further allows advanced cell designs that minimize the anode-cathode distance, ACD, and provides for the continuous collection of liquid aluminum.

$\mathrm{TiB}_{2}$-carbon composites, TCC, were subsequently developed that retained the basic advantages of $\mathrm{TiB}_{2}$ while reducing the disadvantages of higher cost and extreme brittleness. Recent studies have been made using TCC in small experimental prototype electrolysis cells. These studies have shown that molten aluminum penetrates the open pores of the composites along the $\mathrm{TiB}_{2}$ particles that are wetted by the aluminum in contrast to the non-wetting of the carbon component. They observed that $\mathrm{Al}_{2} \mathrm{O}_{3}$ formed by the reaction of molten aluminum with oxygen in the composite. The $\mathrm{TiB}_{2}$ used in this Canadian study contained up to $1 \mathrm{wt} . \%$ $\mathrm{O}_{2}$. Their study further suggested that $\mathrm{Al}_{2} \mathrm{O}_{3}$ dissolved in the electrolyte bath enhanced the dissolution of the $\mathrm{TiB}_{2}$ particles in the electrolyte bath.

Australian workers have shown that even dense hot-pressed $\mathrm{TiB}_{2}$ electrodes are subject to melt penetration. They demonstrated that controlled oxidation of the $\mathrm{TiB}_{2}$ electrodes in melts not saturated with $\mathrm{Al}_{2} \mathrm{O}_{3}$ has no adverse effects on the remarkable characteristic aluminum 
wettability of the $\mathrm{TiB}_{2}$ electrodes, but alumina saturated melts cause the formation of $\mathrm{TiO}_{2}$ and $\mathrm{B}_{2} \mathrm{O}_{3}$ at the electrode surface which interferes with aluminum deposition and wettability.

The availability of lower cost, dense $\mathrm{TiB}_{2}$ shapes has been advanced through the use of sintering aids. These are surface-active elements that are added to the pre-fabrication $\mathrm{TiB}_{2}$ powders, in small amounts that tend to concentrate at the grain boundaries during sintering and densification. This concentration retards the grain growth producing a fine grained, dense microstructure. However, some of the most commonly used sintering aids for $\mathrm{TiB}_{2}$ are $\mathrm{Fe}, \mathrm{Ni}$ and $\mathrm{Cr}$. These elements need to be held to very low levels in the aluminum produced, and candidate oxygen-evolving anodes may already contain them. The degree to which these elements tend to be leached out of the $\mathrm{TiB}_{2}$ grain boundaries into molten aluminum in contact with $\mathrm{TiB}_{2}$ is not known and its determination is one of the objectives of this proposal.

While we do not know how much wetting is needed for optimum or even acceptable performance of vertical plate cathodes, we believe that the wetting of $\mathrm{Al}$ on the $\mathrm{TiB}_{2}$ should be as good as possible; i.e., a contact angle of zero if possible (see Section 5.3-5.4.3.3 for a definition of contact angle and wettability). This would lead to the thinnest aluminum film and the best drainage of aluminum into the sump. Wetting is particularly sensitive to joints in the $\mathrm{TiB}_{2}$ plates. There have been many instances of aluminum balling up above a joint and not bridging the joint. No experiments were conducted on $\mathrm{TiB}_{2}$ surfaces held in either vertical orientation or as inclined planes.

\section{3-5.4.2. Objective}

Poor wetting of vertical $\mathrm{TiB}_{2}$ cathode plates is held to be one of the contributing factors to poor current efficiency in bench-scale aluminum electrolysis cells (see section 5.3-9 of this report). A better understanding of how commercial $\mathrm{TiB}_{2}$ materials differ with respect to their wetting properties is therefore needed. The objective of the study reported in this section was to gain a basic understanding of the wetting of well-characterized $\mathrm{TiB}_{2}$ by molten aluminum under carefully-controlled experimental conditions. Previous studies have involved too many variables to isolate their individual significance. This study focused on the wetting of unalloyed aluminum on well-characterized, commercially available dense $\mathrm{TiB}_{2}$ substrates in controlled gaseous environments in the absence of electrolytic baths. A few measurements of wetting in the presence of the molten salt electrolyte were conducted, but further study of this area is required.

\section{3-5.4.3. Experimental Approach}

\section{3-5.4.3.1 The $\mathrm{TiB}_{2}$ Substrates}

A survey of the current vendors of dense $\mathrm{TiB}_{2}$ shapes was made. Included in this survey was the available information on the names and production capacities of the vendors, the range of

\footnotetext{
2 Typical sintering aids for hot-pressed parts are $\mathrm{Fe}, \mathrm{Ni}, \mathrm{Co}, \mathrm{C}, \mathrm{W}, \mathrm{WC}$ while $\mathrm{C}+\mathrm{Cr}$, Fe, or $\mathrm{CrC}$ are used to aid densification during pressureless sintering while B4C is added to inhibit grain growth (Mroz 2000).
} 
sizes and shapes, densities, additives and trace chemistries available. The results of this survey are included at the end of this section. Based on this survey and Alcoa experiences with other materials, samples of the materials listed in Tables 5.3-5.4-1 and 5.3-5.4-2 were selected for the wetting studies. Chemical and physical properties are that were considered relevant to the wetting studies were determined. Table 5.3-5.4-1 records the chemistry of the samples (with the exception of Ti and B) as measured by Glow Discharge Mass Spectroscopy (GDMS).

Table 5.3-5.4-1. Chemical Impurities in the $\mathbf{T i B}_{2}$ Samples of This Study (Elements near or greater than 50ppm as analyzed by GDM in decreasing order of abundance- $\mathrm{Fe}, \mathrm{W}, \mathrm{Ni}, \mathrm{Nb}, \mathrm{Cr}$, and $\mathrm{Zr}$ shown no matter what level)

\begin{tabular}{|c|c|c|c|c|c|c|c|c|c|c|c|c|}
\hline & Purity & & & & & & & & & & & \\
\hline \multirow[t]{2}{*}{ Alcoa } & & $\mathrm{Si}$ & $\mathrm{Fe}$ & $\mathrm{W}$ & $\mathrm{Ni}$ & $\mathrm{Cr}$ & $\mathrm{Nb}$ & $\mathrm{Zr}$ & & & & \\
\hline & $97.73 \%$ & 350 & 270 & 11 & 10 & 8.6 & 3.6 & 0.48 & & & & \\
\hline \multirow[t]{2}{*}{ Cercom } & & $\mathrm{Cl}$ & $\mathrm{Zr}$ & $\mathrm{Nb}$ & $\mathrm{Fe}$ & $\mathrm{Al}$ & $\mathrm{Na}$ & $\mathrm{Si}$ & & & & \\
\hline & $98.79 \%$ & 600 & 230 & 140 & 120 & 96 & 95 & 63 & & & & \\
\hline \multirow{2}{*}{$\begin{array}{l}\text { Eagle } \\
\text { Picher }\end{array}$} & & $\mathrm{W}$ & $\mathrm{Fe}$ & $\mathrm{Nb}$ & Co & $\mathrm{Zr}$ & $\mathrm{Cr}$ & $\mathrm{Ni}$ & & & & \\
\hline & $98.30 \%$ & 6500 & 650 & 560 & 450 & 310 & 150 & 7.2 & & & & \\
\hline \multirow[t]{2}{*}{ Kubota } & & $\mathrm{Ni}$ & W & $\mathrm{Al}$ & $\mathrm{Fe}$ & Mo & $\mathrm{Cr}$ & $\mathrm{Si}$ & $\mathrm{Ca}$ & $\mathrm{Zr}$ & $\mathrm{Nb}$ & $\mathrm{Mg}$ \\
\hline & $91.35 \%$ & 55,000 & 8000 & 5500 & 1600 & 1200 & 1200 & 1100 & 450 & 220 & 200 & 76 \\
\hline
\end{tabular}

Table 5.3-5.4-1 (Continued) Additional Elements

\begin{tabular}{|l|l|l|l|}
\hline & \multicolumn{1}{|c|}{ C } & \multicolumn{1}{c|}{ N } & \multicolumn{1}{c|}{ O } \\
\hline Alcoa & 22,000 & $<5$ & 35 \\
\hline Cercom & 7500 & 250 & 3000 \\
\hline Eagle Picher & 5000 & 840 & 2500 \\
\hline Kubota & 1700 & 2300 & 8000 \\
\hline
\end{tabular}

Those elements present at levels much below $50 \mathrm{ppm}$ are not included. In this technique, the sample becomes a cathode and material is sputtered into the reactive plasma where it ionizes. Small pins were cut from the bulk samples and it is estimated that during the analysis $20-50$ microns of material were removed from the sample surface. This is therefore a bulk analysis in the context of the present study. The relative purity is computed from those elements listed in the Table 5.3-5.4-1 assuming the remainder to be titanium and boron. Worthy of note is the $5.5 \mathrm{wt} . \% \mathrm{Ni}$ in the Kubota material and the $2.2 \mathrm{wt}$ \% C in the Alcoa sample. The latter stems from the paraffin wax binder used to produce this material (Baumgartner and Steiger 1984). 
Table 5.3-5.4-2 Density of the $\mathrm{TiB}_{2}$ Samples of This Study

\begin{tabular}{|l|c|c|c|}
\hline \multicolumn{1}{|c|}{ Sample } & $\begin{array}{l}\text { Density } \\
\mathrm{g} / \mathrm{cm}^{3}\end{array}$ & $\begin{array}{c}\text { Percent of } \\
\text { Theoretical Density }\end{array}$ & $\begin{array}{c}\text { Percent Apparent } \\
\text { (Open) Porosity }\end{array}$ \\
\hline Alcoa 86 & 4.376 & $97.2(1)$ & 0.209 \\
\hline Cercom & 3.115 & $69.2(2)$ & 28.580 \\
\hline Eagle Picher & 4.487 & $99.7(2)$ & 0.228 \\
\hline Kubota & 4.438 & $93.2(3)$ & 0.331 \\
\hline
\end{tabular}

(1) accounted for some uncombined C

(2) theoretical density of titanium diboride $=4.52 \mathrm{~g} / \mathrm{cm}^{3}$

(3) accounted for presence of $\mathrm{Ni}$

The scanning electron microscope (SEM) images of fracture surfaces of the four $\mathrm{TiB}_{2}$ samples shown in Figure 5.3-5.4-1 emphasizes that the Cercom material has a very open and porous structure, the Kubota material has noticeable closed porosity, and the Alcoa and Eagle Picher materials are dense with low porosity. The difference in $\mathrm{TiB}_{2}$ grain size of the latter materials is also apparent. 


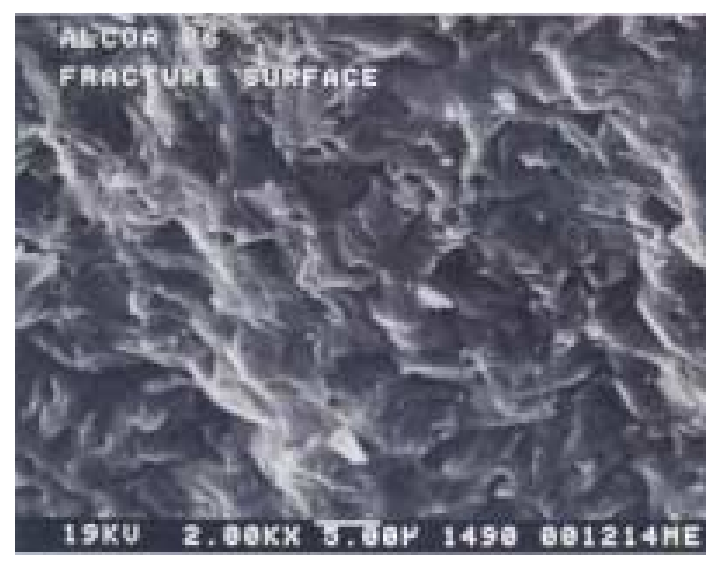

a) Alcoa, $0.21 \%$ apparent porosity

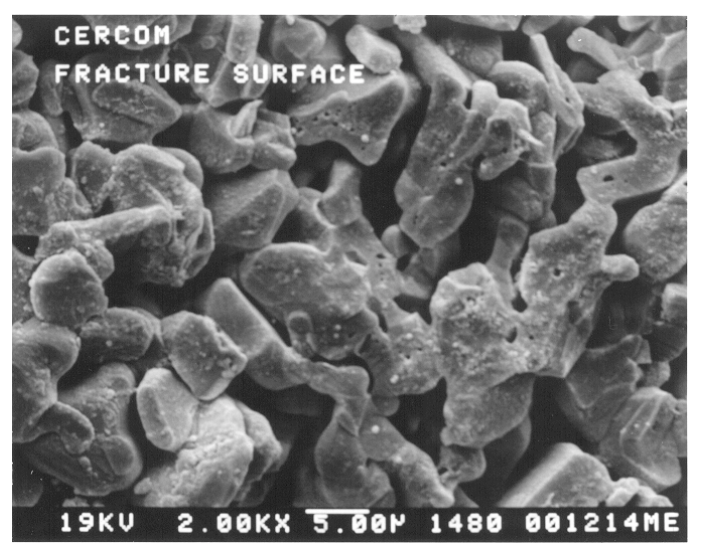

c) Cercom, $28.6 \%$ apparent porosity

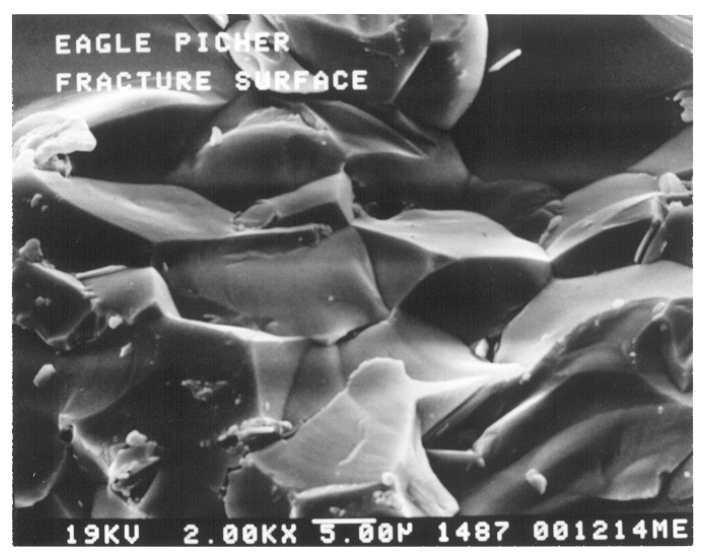

b) Eagle Picher, $0.23 \%$ apparent porosity

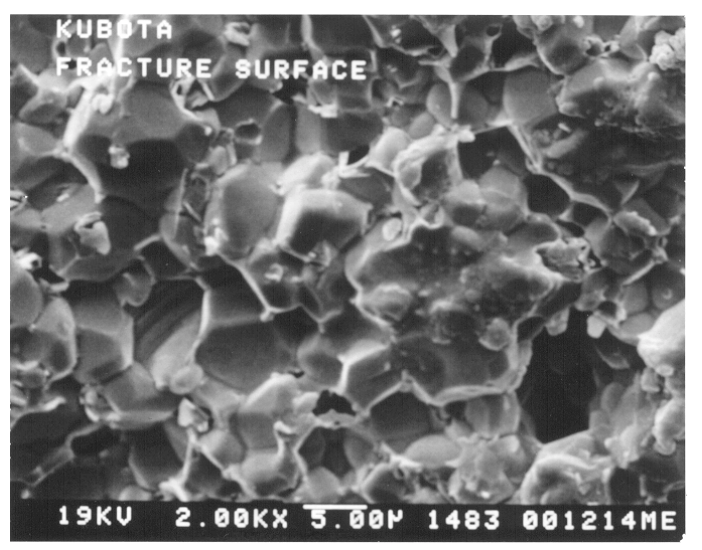

d) Kubota, $0.33 \%$ apparent porosity

Figure 5.3-5.4-1. SEM views of fracture surfaces of the $\mathrm{TiB}_{2} \mathrm{Samples}_{\text {of }}$ this study

\section{3-5.4.3.2 The Aluminum and Salt}

Aluminum of $99.98 \%$ purity or higher was used in the experiments. The vacuum wetting experiments conducted at Alcoa Technical Center (ATC) used 6N Al shot (0.08-0.09 g) from Aesar Co. (13 ppm Si, 12 ppm Zn, 11 ppm Ga, 10 ppm Fe, 5 ppm Mg, 3 ppm or less others). The salt cover wetting experiments conducted at ATC used a 99.988\% Al produced by Alcoa (40 ppm Si, 30 ppm Fe, 10 ppm each Zn, Ga, Mn, V, B). Aesar/alpha 5N grade Al was used in the University of Missouri-Rolla (UMR) wetting experiments. 1.3-2.9 g pieces of $5 \mathrm{~N} \mathrm{Al}$ produced by Alcoa were used in Al-Salt-TiB 2 experiments conducted at ATC. The molten salt cover used in the latter experiments was purified Hall Cell Bath that had an alumina content of 5.9 wt. \% (LECO analysis), a bath ratio (weight $\mathrm{NaF}: \mathrm{AlF}_{3}$ ) of 1.10 (XRD technique), and a nominal $\mathrm{CaF}_{2}$ content of 5 wt.\%. 


\section{3-5.4.3.3 The Sessile Drop Wetting Experiments}

A series of sessile-drop wetting studies were conducted using liquid drops formed from highpurity aluminum on the selected $\mathrm{TiB}_{2}$ solid substrates. Parallel studies were conducted at UMR and ATC using two different techniques.

The first schematic in the following figures depicts wetting conditions where the contact angle is between 0 and 90 degrees. Perfect wetting is at 0 degrees. The second schematic depicts non-wetting conditions where the contact angle is between 91 and 180 degrees.

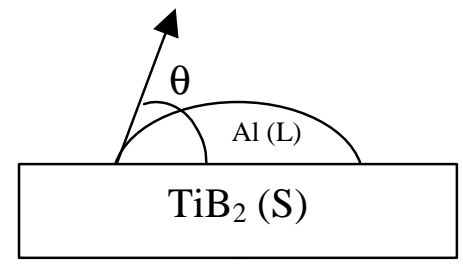

(A). Wetting $\left(\theta<90^{\circ}\right)$ condition

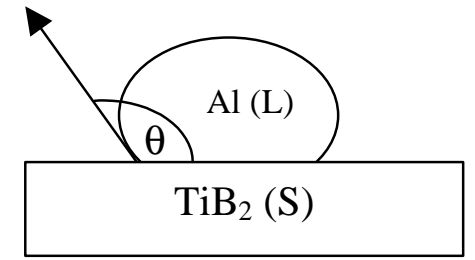

(B). Non-wetting $\left(\theta>90^{\circ}\right)$ condition

Figure 5.3-5.4-2. The sessile drop configuration and contact angles.

\section{3-5.4.3.31 Low $\mathrm{O}_{2}$ Experiments at 1 atm Total Pressure}

At UMR, the aluminum drop was placed on the $\mathrm{TiB}_{2}$ substrates at high temperature in a controlled atmosphere using the doser technique developed at UMR (Ownby et al. 1991). This allowed the substrate to come into equilibrium with the reducing gas stream at temperature prior to drop placement (Figure 5.3-5.4-3).

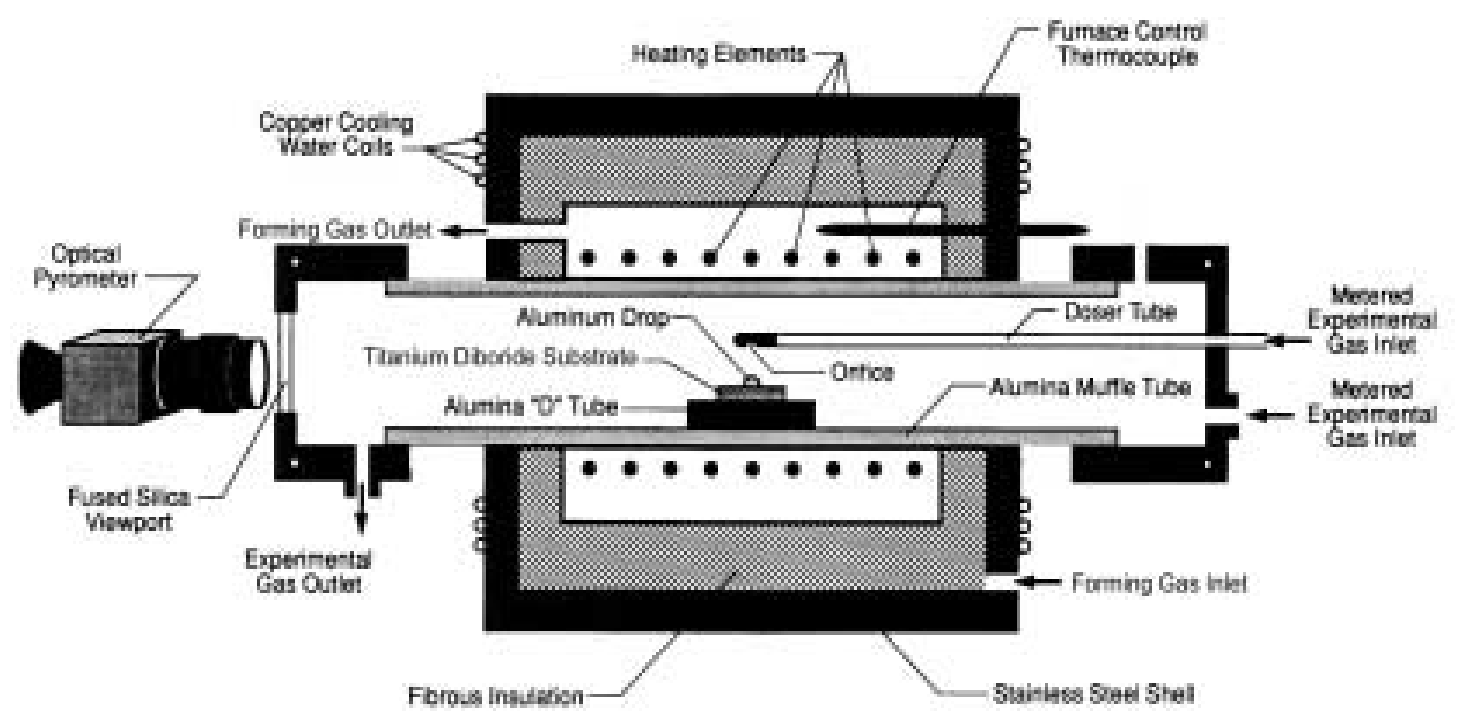

Figure 5.3-5.4-3. The UMR low $\mathrm{O}_{2}$ sessile drop furnace. 
The oxygen content of the ultra high purity hydrogen atmosphere was held low enough to prevent substrate oxidation, and held as low as possible to limit the rate of oxidation of the liquid aluminum drop. It was measured with a solid electrolyte furnace system (Figure 5.35.4-4). The sessile drop contact angle was monitored in situ for 8 hours by video and still digital and by still positive/negative Polaroid photography. The ambient atmosphere was reduced in oxygen partial pressure and the $\mathrm{pO}_{2}$ was continuously controlled and monitored during the runs.

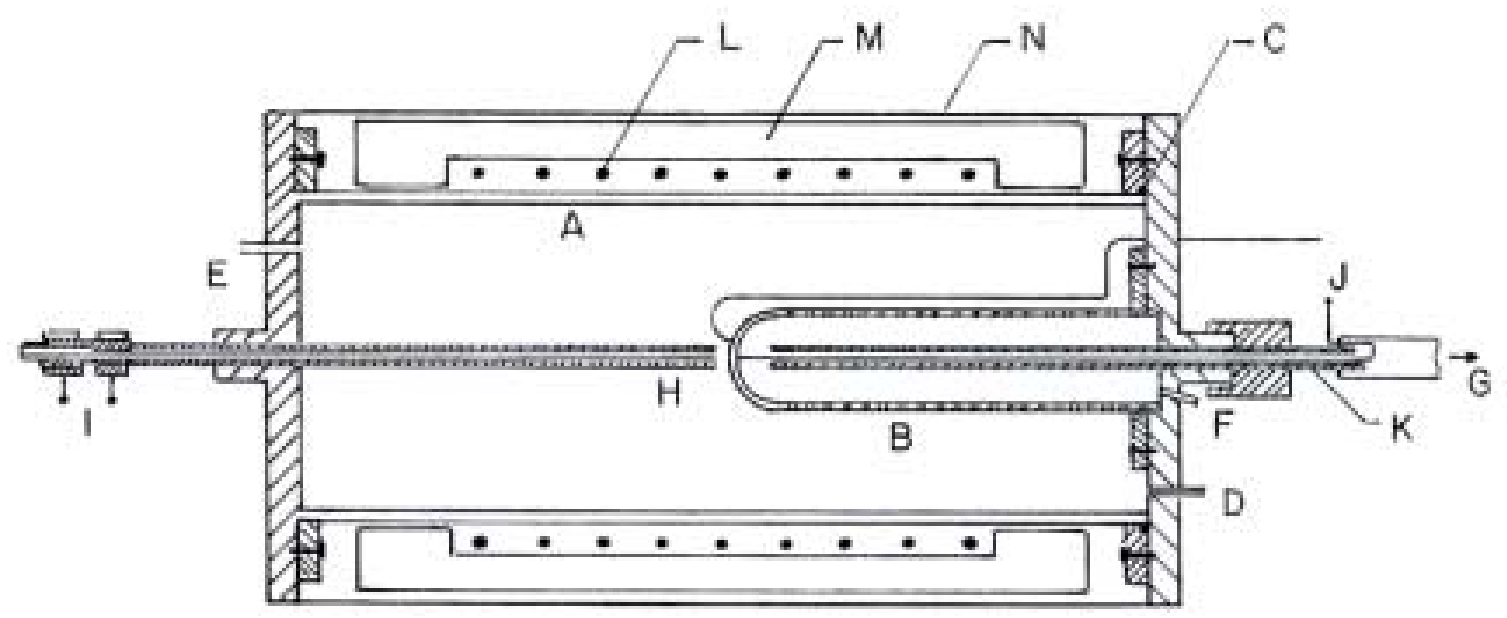

Figure 5.3-5.4-4. The UMR $\mathrm{pO}_{2}$ sensor

(A) $\mathrm{Al}_{2} \mathrm{O}_{3}$ tube, (B) $\mathrm{ThO}_{2}-7 \mathrm{wt} \% \mathrm{Y}_{2} \mathrm{O}_{2}$ tube, (C) Flange and O-ring seals, (D) Experimental gas inlet,

(E) Experimental gas outlet, (F) Reference gas inlet, $(\mathrm{G})$ Reference gas outlet, $(\mathrm{H})$ Thermocouple,

(I) Thermocouple output, (K) $\mathrm{Al}_{2} \mathrm{O}$ gas carrier tube with galvanic lead, (L) Heating element(M) Insulation,

(N) Metal shell.

\section{3-5.4.3.32 Graphite Furnace Vacuum Experiments}

At ATC, a graphite-lined vacuum furnace was used to form the drop in situ during the ramp to the experimental temperature (Figure 5.3-5.4-5).

The contact angle was measured directly using a telegoniometer (Weirauch 1988). In both techniques, the main concern is to minimize the amount of oxide that forms on the liquid aluminum drop so that it does not interfere to a significant extent with the formation of the liquid drop/solid $\mathrm{TiB}_{2}$ substrate interface.

1. Post wetting trace chemical analyses were performed on selected aluminum drops. Particular attention was paid to the pick-up of the substrate sintering additives in the aluminum drop to determine if contamination of aluminum in cells with $\mathrm{TiB}_{2}$ cathodes is of concern with each different $\mathrm{TiB}_{2}$ source. 
2. Post wetting chemical and microstructural analyses of the underlying $\mathrm{TiB}_{2}$ substrate were made to determine the extent of chemical interaction and penetration of the $\mathrm{TiB}_{2}$ by aluminum.

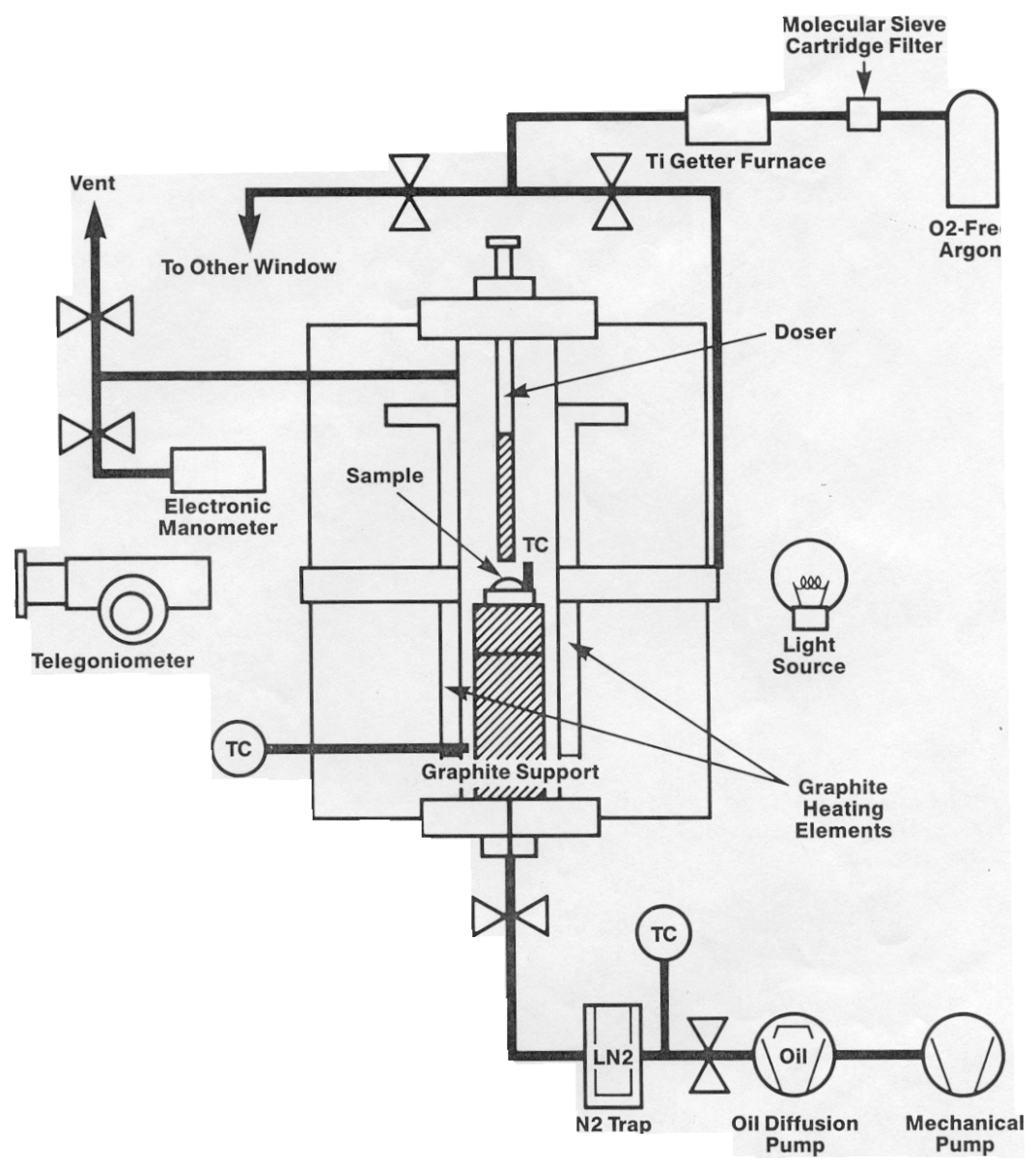

Figure 5.3-5.4-5 The ATC carbon furnace vacuum wetting apparatus.

\section{3-5.4.3.33 Wetting Experiments in the Presence of Molten Salt}

A few experiments were conducted under a molten salt cover to assess the effect of the salt on substrate wetting behavior. In these experiments dried $\mathrm{O}_{2}$-free argon was passed over the surface of a Hall Cell salt bath $\left(\mathrm{NaF}: \mathrm{AlF}_{3}=1.10\right.$ by weight, $\mathrm{Al}_{2} \mathrm{O}_{3}=5.9$ wt. $\%, \mathrm{CaF}_{2}=5$ wt. \%) at a flow rate of $0.75 \mathrm{cc} / \mathrm{min}$. The $55 \mathrm{~g}$ salt bath was contained in a graphite crucible with the $\mathrm{TiB}_{2}$ substrate at its bottom. The graphite crucible was contained in an outer alumna crucible. After the bath had been held for $1 \mathrm{hr}$ at $960^{\circ} \mathrm{C}$, a 2.6-3.0 gram piece of $99.988 \% \mathrm{Al}$ purity was dropped onto the substrate. The crucible was removed from the furnace after the desired hold time. Loose salt was mechanically removed from the sessile drop sample and metallographic cross sections were prepared. 


\section{3-5.4.4 Results and Discussion}

\section{3-5.4.4. 1 Low $\mathrm{O}_{2}$ Wetting Experiments at 1 atm Total Pressure}

A considerable amount of experimental effort was expended in reducing the oxygen content of the hydrogen furnace atmosphere to low enough levels so that oxidation of the aluminum sessile drop would not interfere with the contact angle measurements.

Initial experiments resulted in excessive oxidation of the drop even with $5 \mathrm{~N}$ hydrogen with $<1 \mathrm{ppm} \mathrm{O}_{2}$ and $<2 \mathrm{ppm} \mathrm{H}_{2} \mathrm{O}$. In order to lower the $\mathrm{pO}_{2}$ of the atmosphere, a Millipore Micro molecular filter was installed. According to its specifications, the Ultra High Purity grade 5 $(99.999 \%)$ hydrogen will flow into the filter and the hydrogen flowing out of it into the system will contain $<1 \mathrm{ppb} \mathrm{O}_{2}$ and $\mathrm{H}_{2} \mathrm{O}$. This is 1000 times lower than the cleanest available tank grade 6 (99.9999\%) hydrogen, research grade. This is equivalent to that produced by a palladium diffuser unit, which produces $9 \mathrm{~N} \mathrm{H}$.

The lowest levels attained were in the $10^{-19}$ to $10^{-24}$ atmosphere range at $1025^{\circ} \mathrm{C}\left(\mathrm{pO}_{2}=10^{-34}\right.$ atm is the approx. metal/oxide equilibrium value). In most cases the temperature of the wetting had to be greatly increased (to the temperature for metal/oxide equilibrium at the attainable experimental $\mathrm{pO}_{2}$ ) before the liquid aluminum wetting behavior could be observed. The wetting behavior varied greatly for each of the four $\mathrm{TiB}_{2}$ substrates of this study (Table 5.3-5.4-3) and is summarized by the following statements:

- Alcoa substrate: a stable contact angle of $126^{\circ}$ up to an $8 \mathrm{hr}$ hold,

- Eagle Picher substrate: the contact angle fell from 98 to $79^{\circ}$ during the $8 \mathrm{hr}$ hold at at $1025^{\circ} \mathrm{C}$.

- Cercom substrate: aluminum was held in its oxide shell at $1025^{\circ} \mathrm{C}$ and only broke out to a spreading condition when the temperature was raised to $1300^{\circ} \mathrm{C}$,

- Kubota substrate: aluminum spread out over the substrate at $1025^{\circ} \mathrm{C}$ in a few minutes. 
Table 5.3-5.4-3. Summary of the UMR Wetting Experiments

\begin{tabular}{|l|l|l|l|c|c|l|}
\hline \multicolumn{1}{|c|}{ Run } & \multicolumn{1}{|c|}{$\begin{array}{c}\mathrm{TiB}_{2} \\
\text { Supplier }\end{array}$} & $\begin{array}{c}\text { Total } \\
\text { Pressure }\end{array}$ & $\begin{array}{c}\text { Oxygen Partial } \\
\text { Pressure }\left(\mathrm{pO}_{2}\right)\end{array}$ & $\begin{array}{c}\mathrm{H}_{2} \\
\text { Purity }\end{array}$ & $\begin{array}{c}\text { Furnace } \\
\text { Temp }\left({ }^{\circ} \mathrm{C}\right)\end{array}$ & \multicolumn{1}{|c|}{$\begin{array}{c}\text { Contact } \theta \\
\text { Initial } / \text { Final }\end{array}$} \\
\hline EPR - A & Eagle Picher & $1 \mathrm{~atm}$ & & $4 \mathrm{~N}$ & $1025^{\circ} \mathrm{C}$ & $90^{\circ} / 89^{\circ}$ \\
\hline EPR - B & Eagle Picher & $1 \mathrm{~atm}$ & & $5 \mathrm{~N}$ & $1025^{\circ} \mathrm{C}$ & $116^{\circ} / 96^{\circ}$ \\
\hline EPR - C & Eagle Picher & $1 \mathrm{~atm}$ & & $5 \mathrm{~N}$ & $1025^{\circ} \mathrm{C}$ & $103^{\circ} / 102^{\circ}$ \\
\hline EPR - D & Eagle Picher & $1 \mathrm{~atm}$ & $1.6 \times 10^{-24} \rightarrow 1 \times 10^{-19}$ & $9 \mathrm{~N}$ & $1025^{\circ} \mathrm{C}$ & $98^{\circ} / 79^{\circ}$ \\
\hline EPR - E & Eagle Picher & 30 torr & & $9 \mathrm{~N}$ & $1400^{\circ} \mathrm{C}$ & $95^{\circ} / 0^{\circ} *$ \\
\hline EPR - F & Eagle Picher & 30 torr & & $9 \mathrm{~N}$ & $1300^{\circ} \mathrm{C}$ & $90^{\circ} / 75^{\circ} \rightarrow 0^{\circ} *$ \\
\hline CRM - A & Cercom & 30 torr & & $9 \mathrm{~N}$ & $1400^{\circ} \mathrm{C}$ & $\mathrm{NA} / 0^{\circ} *$ \\
\hline KBT - A & Kubota & 30 torr & & $9 \mathrm{~N}$ & $1025^{\circ} \mathrm{C}$ & $\mathrm{NA} / 24^{\circ}$ \\
\hline ALC - A & Alcoa & 30 torr & & $9 \mathrm{~N}$ & $1335^{\circ} \mathrm{C}$ & $112^{\circ} / 6^{\circ} *$ \\
\hline ALC - B & Alcoa & 1 atm & $1.6 \times 10^{-24} \rightarrow 1 \times 10^{-19}$ & $9 \mathrm{~N}$ & $1025^{\circ} \mathrm{C}$ & $126^{\circ} / 126^{\circ}$ \\
\hline KBT - B & Kubota & $1 \mathrm{~atm}$ & $1.6 \times 10^{-24} \rightarrow 1 \times 10^{-19}$ & $9 \mathrm{~N}$ & $1025^{\circ} \mathrm{C}$ & $\mathrm{NA} / 0^{\circ} *$ \\
\hline CRM - C & Cercom & $1 \mathrm{~atm}$ & $1 \times 10^{-20} \rightarrow 6.5 \times 10^{-16}$ & $9 \mathrm{~N}$ & $1300^{\circ} \mathrm{C}$ & $\mathrm{NA} / 0^{\circ} *$ \\
\hline
\end{tabular}

* Complete wetting underneath oxide shell.

During the drop placement process, the oxygen content of the atmosphere was observed to rise when the drop doser system was valved open. The higher oxygen partial pressure shown in the Table 5.3-5.4-3 represents the highest level or spike related to the dosing process. The lower value is the more typical level that was in the sessile drop furnace before dosing and for most of the experiment after recovery from the drop dosing operation. Despite these low oxygen levels, the contact angle results obtained in the 1 atmosphere, low oxygen experiments were much higher than those expected based on the published literature on the wetting of high-purity titanium diboride under vacuum conditions (Figure 5.3-5.4-6). 


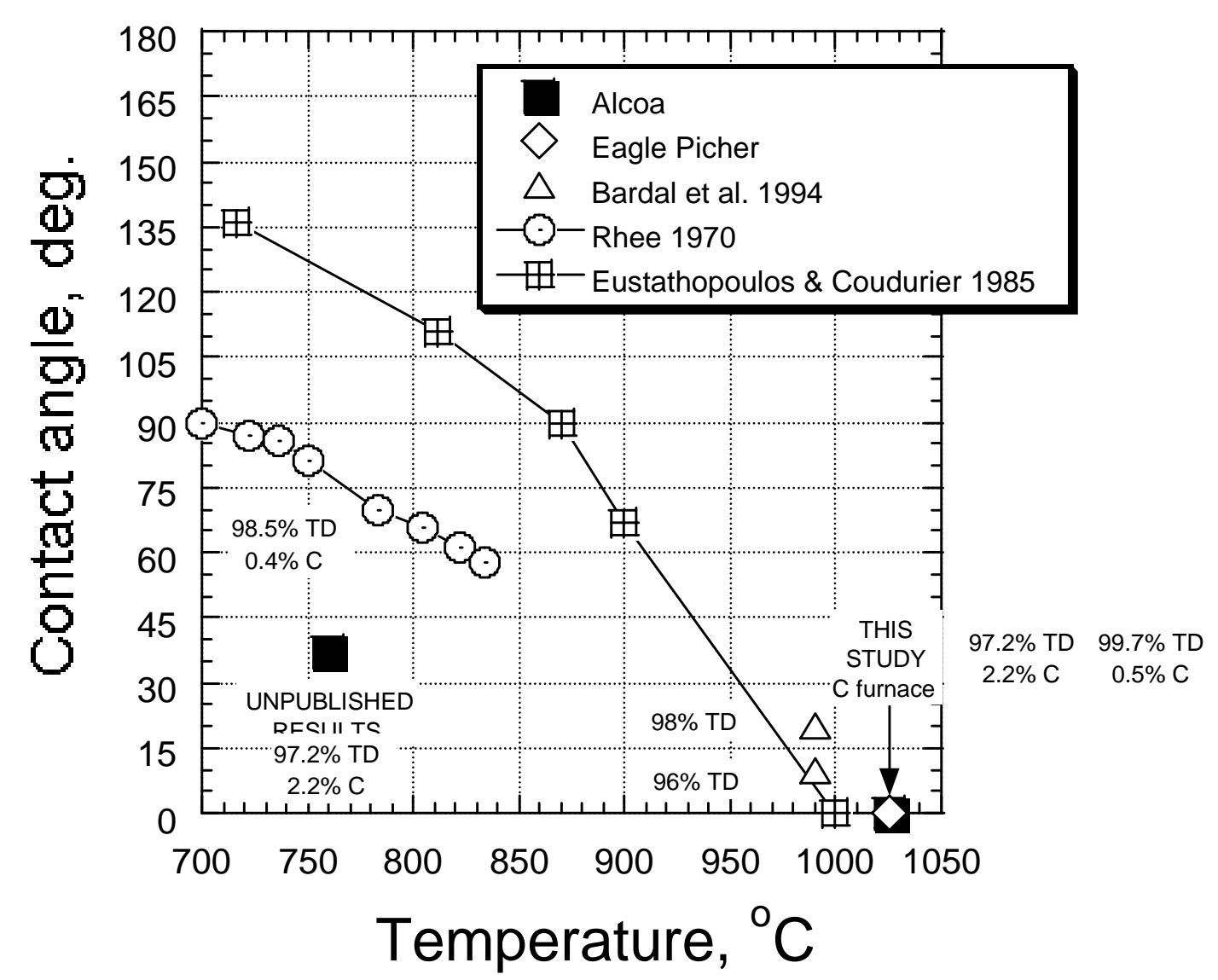

Figure 5.3-5.4-6 The wetting of dense polycrystalline $\mathrm{TiB}_{2}$ by Al under vacuum conditions.

The poor wetting behavior observed in the ultra high purity hydrogen atmosphere prompted several changes to the experimental procedure. The dosing process was eliminated since a rise in oxygen partial pressure was found that related to valving. The aluminum drops were therefore formed in situ by melting a piece of $\mathrm{Al}$ that was placed on the substrate at the beginning of the experiment. In order to remove the influence of gasses desorbed from the cooler ends of the furnace during heatup, a rough vacuum ${ }^{3}$ of approximately 20-40 torr was maintained with a trickle of ultra high hydrogen. The oxygen partial pressure was therefore expected to be similar or better than those attained in the earlier experiments, but the total pressure had been reduced. At the same time temperatures were raised to promote more rapid wetting. The following results were obtained:

- Alcoa substrate: aluminum broke out of its thin oxide shell at $1335^{\circ} \mathrm{C}$ into a contact angle of $112^{\circ}$. The angle decreased to $6^{\circ}$ after a $38 \mathrm{~min}$. spreading period.

\footnotetext{
${ }^{3}$ A gage pressure of 28.5 in. $\mathrm{Hg}$ was recorded
} 
- Eagle Picher substrate: aluminum broke out of its thin oxide shell at $1300-1400^{\circ} \mathrm{C}$ into a contact angle of $90-95^{\circ}$. The angle decreased to $75^{\circ}$ after $8 \mathrm{~min}$. and then spread out over the substrate.

- Cercom substrate: aluminum broke out of its thin oxide shell at $1400^{\circ} \mathrm{C}$ and immediately spread out over the substrate.

- Kubota substrate: aluminum spread out over the substrate at $1025^{\circ} \mathrm{C}$ in a few minutes with a primary drop contact angle of $24^{\circ}$ and a secondary contact angle of $0^{\circ}$.

These results are in better agreement with the available published results for the wetting of $\mathrm{TiB}_{2}$ by aluminum, but very high temperatures were required. The key factor in the different wetting behaviors is not known since temperature and drop formation technique were different for the rough vacuum experiments and the 1 atm low $\mathrm{pO}_{2}$ experiments. The high temperatures render these results of little value for predicting the wetting behavior of different $\mathrm{TiB}_{2}$ materials at more typical cell operation temperatures of $960^{\circ} \mathrm{C}$.

\section{3-5.4.4.2 Graphite-lined Vacuum Furnace Wetting Experiments}

The wetting experiments conducted at ATC in a graphite-lined vacuum furnace are summarized in Figure 5.3-5.4-7.

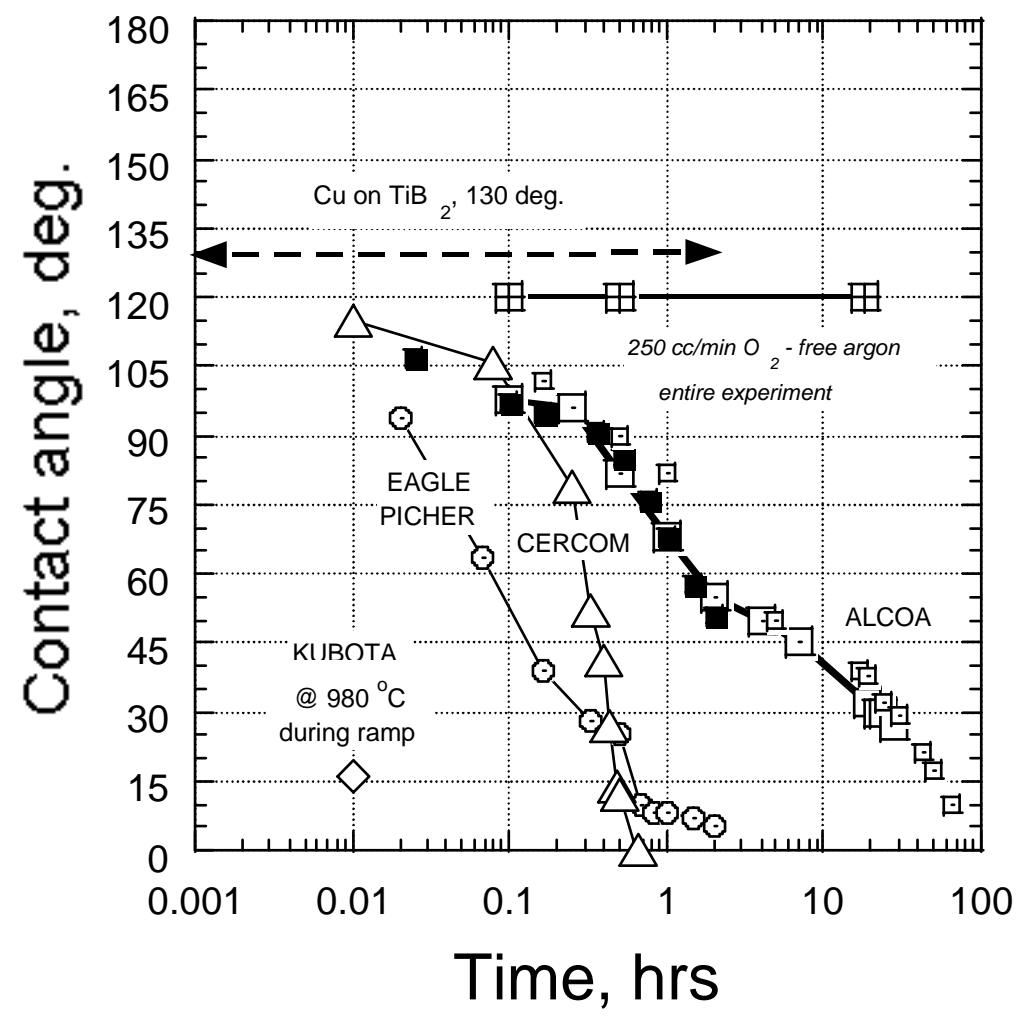

Figure 5.3-5.4-7 The wetting of various $\mathrm{TiB}_{2}$ materials by $\mathrm{Al}$ as revealed by carbon vacuum furnace experiments. 
The observed contact angle on the Kubota substrate fell to 15 degrees before the hold temperature of $1025^{\circ} \mathrm{C}$ was reached. The contact angle on the Cercom substrate fell to $0^{\circ}$ after a 45 minute hold at $1025^{\circ} \mathrm{C}$. The wetting kinetics were slower on the Eagle Picher substrate taking $2 \mathrm{hrs}$ to reach 7 degrees. The slowest wetting kinetics were observed on the Alcoa material where the contact angle was $28^{\circ}$ after $24 \mathrm{hrs}$. These directly observed contact angle changes are a consequence of physical wetting phenomena, chemical reactions and in some cases substrate penetration. These contact angle results for the different substrates can not be interpreted as wetting differences until the extent of chemical reaction and penetration is determined. The results for the Eagle Picher substrate are closest to true wetting behavior. Cross sections through the drop cooled to room temperature revealed no indications of chemical reaction with the substrate or grain boundary penetration (Table 5.3-5.4-4). It was also observed that a thin layer of aluminum that could not be resolved in the telegoniometer had spread along the substrate surface (Figure 5.3-5.4-8).

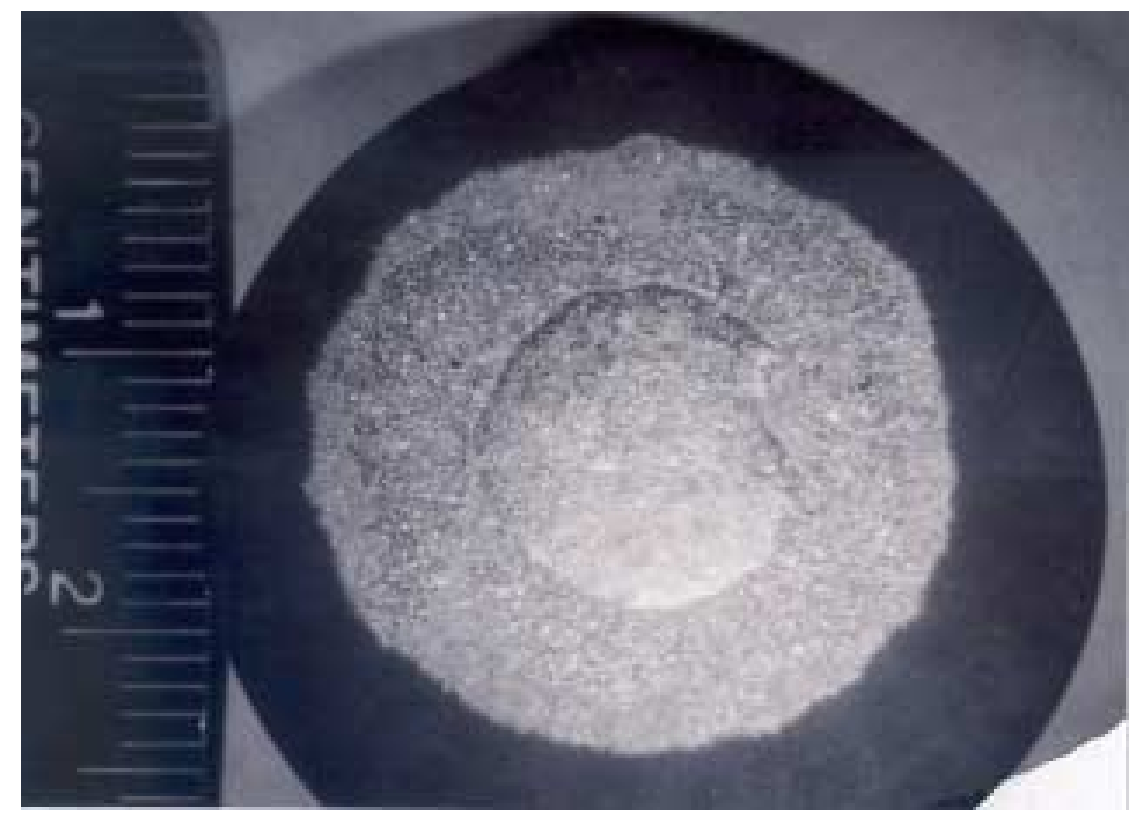

EXPERIMENT R321

Figure 5.3-5.4-8 Secondary spreading observed around the drop perimeter of a wetting experiment of $\mathrm{Al}$ on Eagle Picher $\mathrm{TiB}_{2}$ after cooling to room temperature.

This indicates that a contact angle of zero had been attained on the Eagle Picher $\mathrm{TiB}_{2}$ during the wetting experiment.

When viewed in metallographic cross section, the Alcoa $\mathrm{TiB}_{2}$ substrate also showed little evidence of chemical reaction or substrate penetration (Figure 5.3-5.4-9). A few second phase particles were observed in cross section in the aluminum near the $\mathrm{Al} / \mathrm{TiB}_{2}$ interface and presumed to be $\mathrm{Al}_{4} \mathrm{C}_{3}$. The porous Cercom substrate was penetrated by aluminum so that the observed contact angles changes resulted from a combination of wetting, spreading, and 
penetration phenomena (Figure 5.3-5.4-10). The Kubota substrate reacted and expanded so that the final apparent contact angle was actually the angle formed on the substrate by the reaction product layer (Figure 5.3-5.4-11).

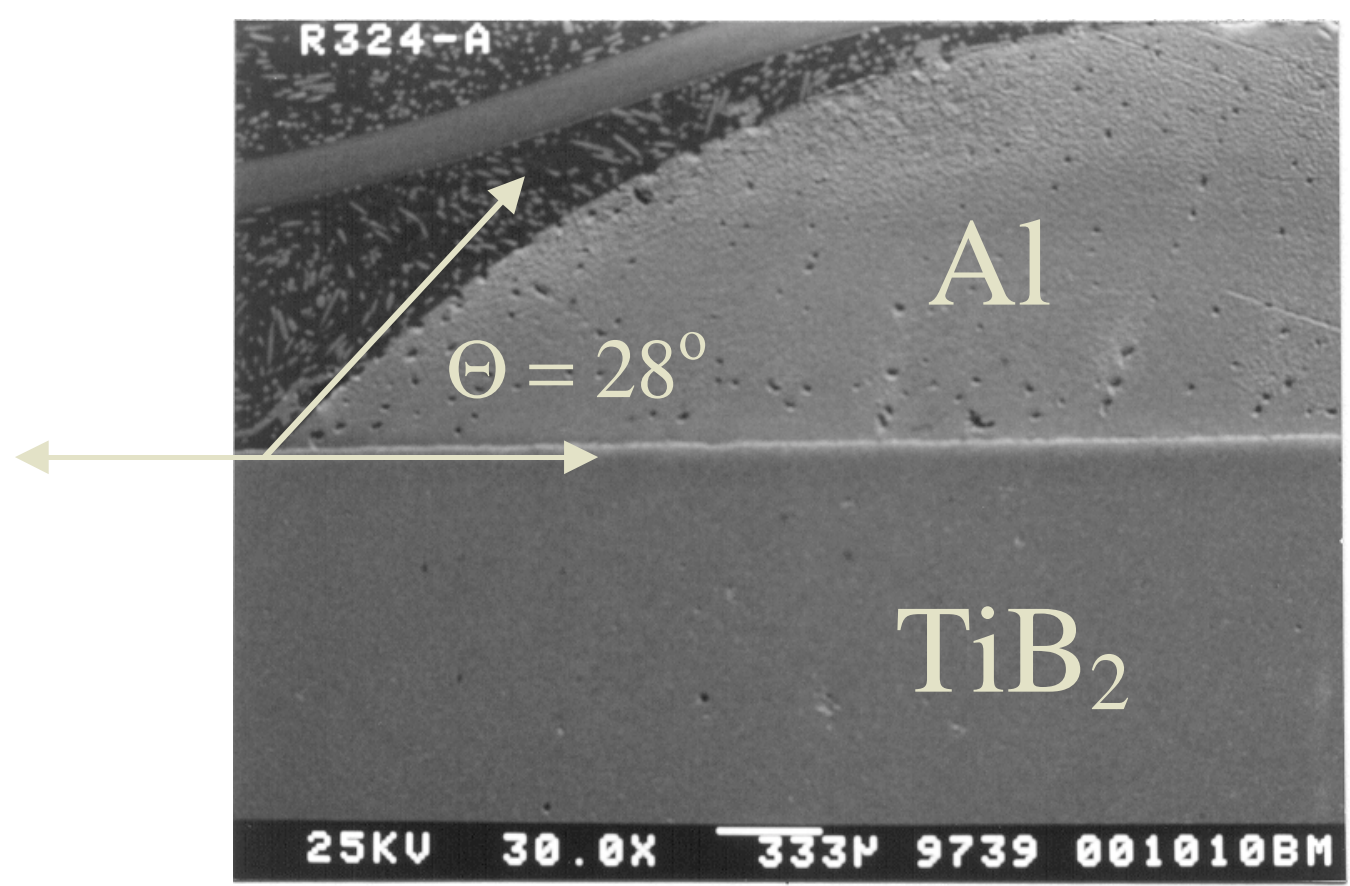

Figure 5.3-5.4-9 Metallographic cross section through the Al sessile drop on Alcoa $\mathrm{TiB}_{2}$ after 2 hrs at $1025^{\circ} \mathrm{C}$ in a $3.8 \times 10^{-4}$ torr vacuum in the carbon-lined furnace. 


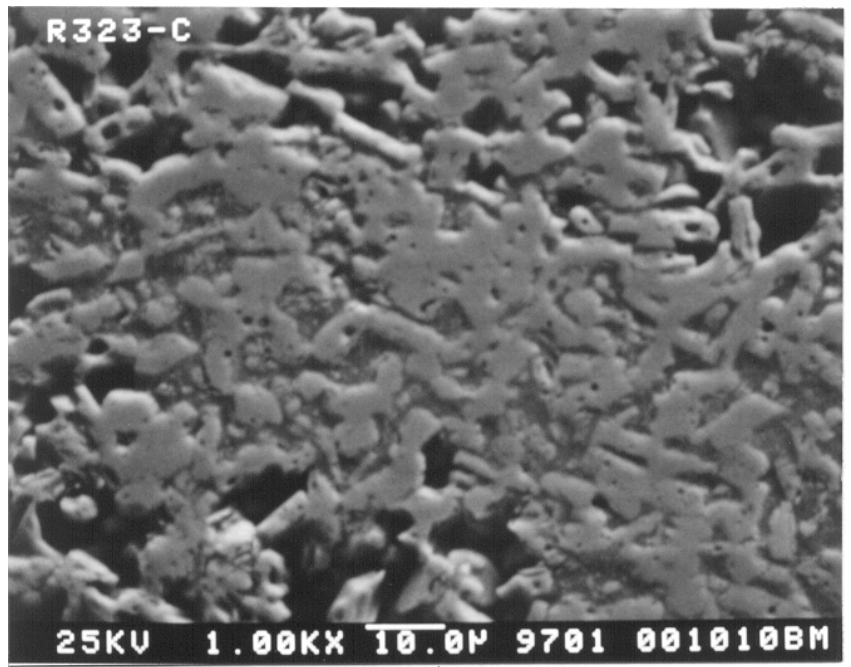

(a) Al-filled pores and open pores within the $\mathrm{TiB}_{2}$ substrate

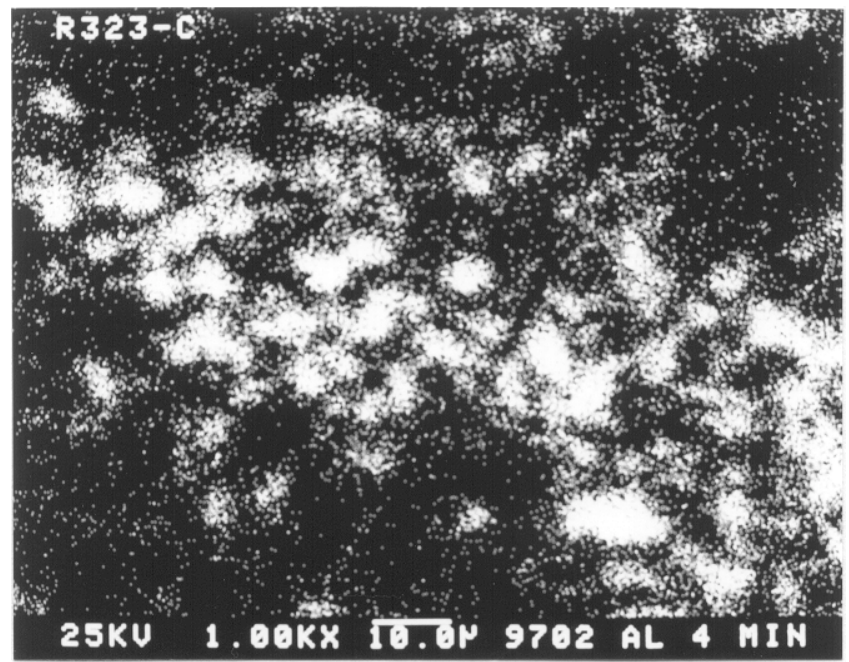

(b) Al dot map

Figure 5.3-5.4-10 Metallographic evaluation of wetting experiment R323 Al on Cercom $\mathrm{TiB}_{2}, 2$ hrs at $1025^{\circ} \mathrm{C}, 5.3 \times 10^{-4}$ torr in carbon-lined furnace 


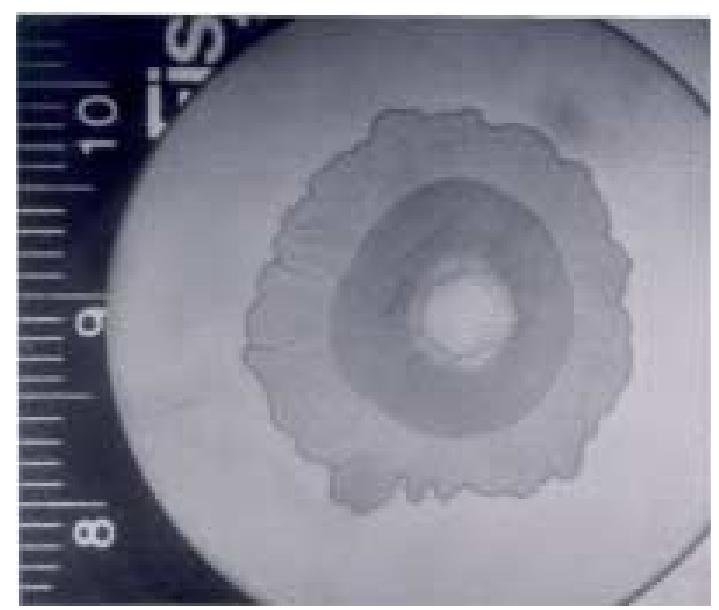

(a) Top view of spreading perimeter

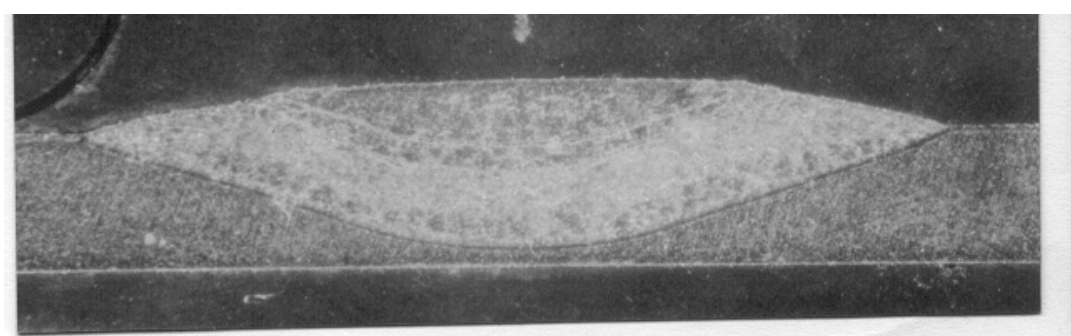

(b) Cross section through drop, $1.8 \mathrm{~mm}$ thick substrate

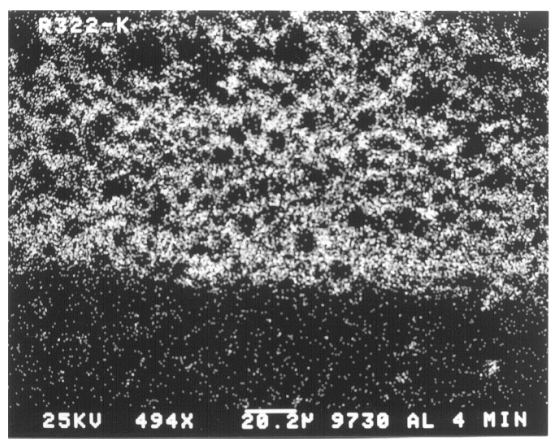

(c) Al dot map

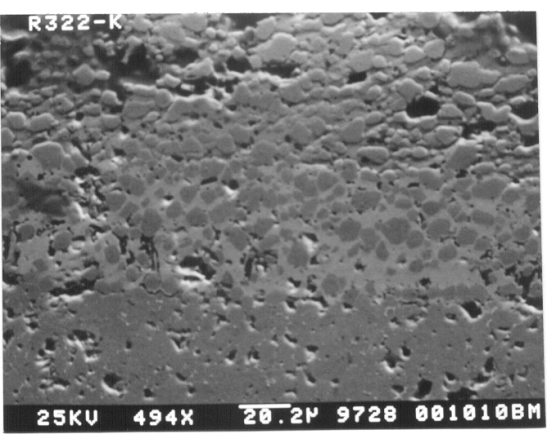

(d) BSE - Back Scattered Electron image

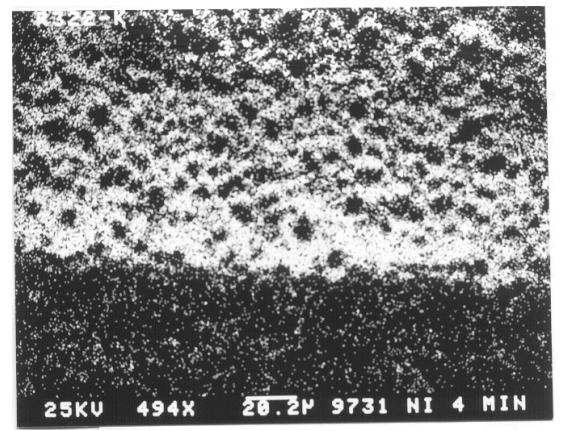

(e) Ni dot map

Figure 5.3-5.4-11 Metallographic valuation of sessile drop experiment R322 Al on Kubota $\mathrm{TiB}_{2} 1$ minute at $1025^{\circ} \mathrm{C}, 2 \times 10^{-3}$ torr in carbon-lined vacuum furnace.

The final contact angles measured under these experimental conditions are in better agreement with the expected behavior at this temperature. Furthermore, this temperature is much closer to typical aluminum electrolysis cell operating temperature of $960^{\circ} \mathrm{C}$ than the $1300-1400^{\circ} \mathrm{C}$ range required to get complete wetting in the vacuum $/ \mathrm{H}_{2}$ experiments described previously. 


\section{3-5.4.4.3 Salt Exposure Tests}

A few experiments were conducted under a molten salt cover to assess the effect of the salt on substrate wetting by aluminum. The surfaces of the Alcoa and Eagle Picher substrates were completely covered by aluminum at $960^{\circ} \mathrm{C}$ after a $1 \mathrm{hr}$ hold. The macroscopic contact angles are edge constrained values for a large aluminum drop so that the true contact is expected to be lower. Since the Al spread around the edges of the $\mathrm{TiB}_{2}$ substrate, the contact angle is assumed to be close to zero. The Cercom and Kubota substrates showed evidence of dewetting after a $1 \mathrm{hr}$ hold. An example of this is shown in Figure 5.3-5.4-12. A few experiments were also conducted to assess the effect of salt exposure only. The results of these tests are summarized in Table 5.3-5.4-4 and discussed in the next section.

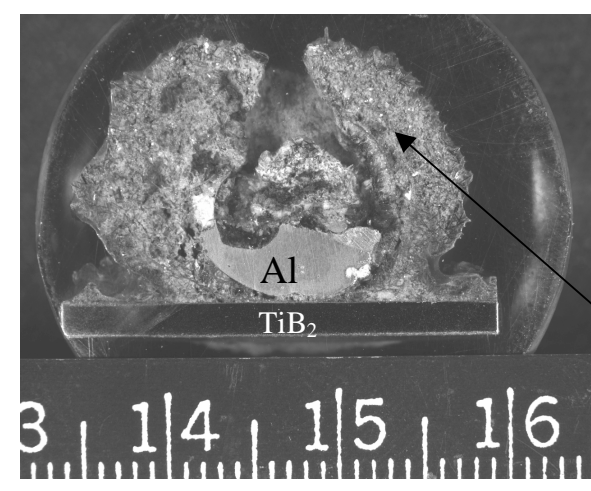

(a) Sample cross section

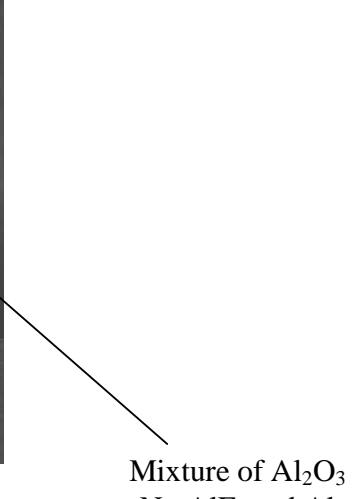

$\mathrm{Na}_{3} \mathrm{AlF}_{6}$ and $\mathrm{Al}$

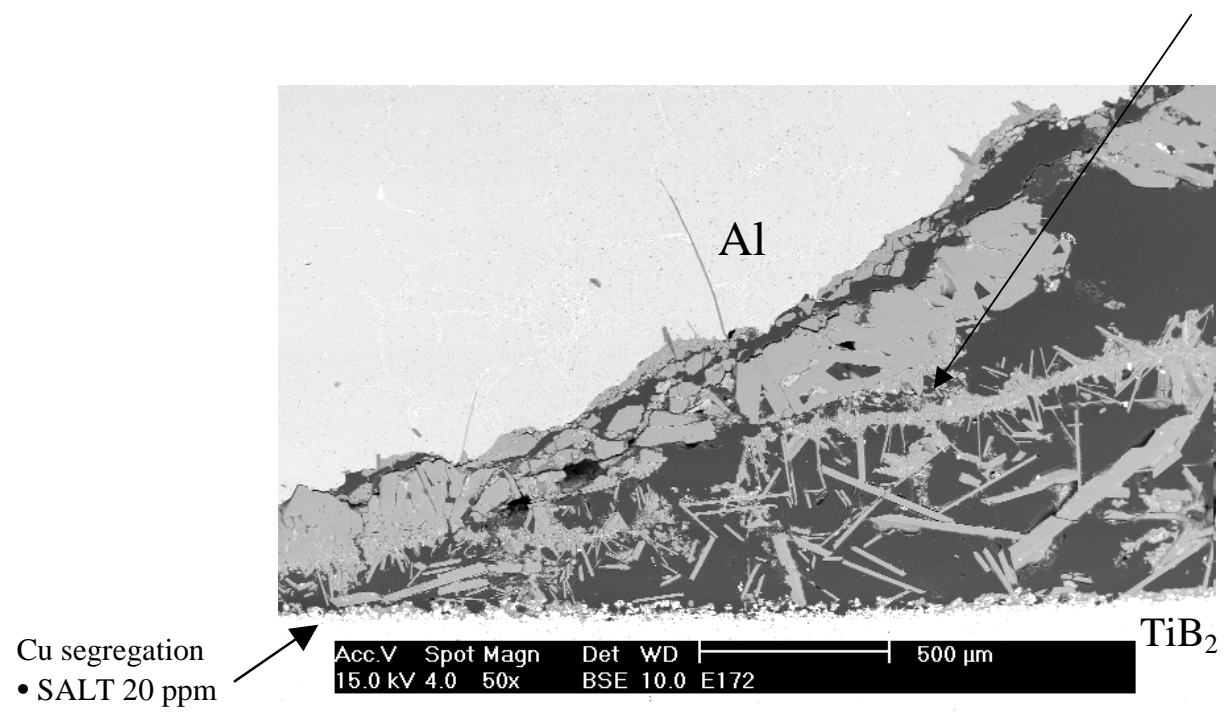

(b) Magnified view

- $\mathrm{TiB}_{2} 2.4 \mathrm{ppm}$

- $\mathrm{Al}<5 \mathrm{ppm}$ Figure 5.3-5.4-12 Dewetting of Al from Eagle Picher $\mathrm{TiB}_{2}$ after 24 hours
at $960^{\circ} \mathrm{C}$ under a Hall Cell cover salt (Experiment E172) 


\section{3-5.4.4. 4 Post-Test Sample Analyses}

Metallographic cross sections were prepared from samples that were exposed to aluminum only, salt only, or aluminum under a molten salt cover. The results are summarized in Table 5.3-5.4-4.

\section{Table 5.3-5.4-4 Chemical Stability the $\mathbf{T i B}_{2}$ Samples Under Different Conditions}

\begin{tabular}{|c|c|c|c|c|}
\hline SAMPLE & EXPER. \# & $\begin{array}{c}\text { TEMP. } \\
{ }^{\circ} \mathrm{C} \\
\end{array}$ & $\begin{array}{c}\text { TIME } \\
\text { hrs }\end{array}$ & OBSERVATIONS \\
\hline $\begin{array}{l}\text { Alcoa TiB }_{2} \\
0.085 \mathrm{~g} \mathrm{Al} \\
\text { vacuum / C }\end{array}$ & R324 & 1025 & 2 & $\begin{array}{l}\text { no GB penetration; } \\
\text { small amount of second phase at } \mathrm{Al} / \mathrm{TiB}_{2} \\
\text { interface }\left(\mathrm{Al}_{4} \mathrm{C}_{3} \text { ?) }\right.\end{array}$ \\
\hline $\begin{array}{l}\text { Alcoa TiB }_{2} \\
0.288 \mathrm{~g} \mathrm{Al} \\
\text { vacuum / C }\end{array}$ & R328 & 1025 & 65 & $\begin{array}{l}\text { nonuniform secondary spreading of } \mathrm{Al} \text { from } \\
\text { sessile drop perimeter }\end{array}$ \\
\hline $\begin{array}{l}\text { Cercom TiB } \\
0.083 \mathrm{~g} \mathrm{Al} \\
\text { vacuum / C }\end{array}$ & R323 & 1025 & 2 & $\begin{array}{l}\text { Al penetration into some pores and other pores } \\
\text { unfilled }\end{array}$ \\
\hline $\begin{array}{l}\text { Eagle Picher } \\
\text { TiB2 } \\
0.086 \mathrm{~g} \mathrm{Al} \\
\text { vacuum / C }\end{array}$ & R321 & 1025 & 2 & $\begin{array}{l}\text { no Al penetration, secondary spreading halo } \\
\text { surrounding central Al drop }\end{array}$ \\
\hline $\begin{array}{l}\text { Kubota TiB } \\
0.085 \mathrm{~g} \mathrm{Al} \\
\text { vacuum / C }\end{array}$ & R322 & 1025 & 0 & $\begin{array}{l}\text { complete } \mathrm{Al} \text { penetration by } 980^{\circ} \mathrm{C}, \\
\mathrm{Ni} \text { pickup by Al }\end{array}$ \\
\hline $\begin{array}{l}\text { Eagle Picher } \\
\mathrm{TiB}_{2} \text { salt } \\
\text { immersion }\end{array}$ & E170 & 960 & 1 & radial fracture of disk, surface attack \\
\hline $\begin{array}{l}\text { Cercom } \mathrm{TiB}_{2} \\
2.6 \mathrm{~g} \mathrm{Al} \\
\text { salt cover }\end{array}$ & E160 & 960 & 1 & $\begin{array}{l}\text { penetration by salt and } \mathrm{Al} \text {, dewetting } \\
\text { possible } \mathrm{AlTi}_{3}\end{array}$ \\
\hline $\begin{array}{l}\text { Alcoa } \mathrm{TiB}_{2} \\
2.6 \mathrm{~g} \mathrm{Al} \\
\text { salt cover }\end{array}$ & E156 & 960 & 1 & $\begin{array}{l}\text { complete substrate coverage with } \\
\text { edge-constrained contact angles of } 24-30^{\circ} \\
20 \text { microns of GB penetration by Al } \\
\text { possible } \mathrm{Al}_{4} \mathrm{C}_{3}\end{array}$ \\
\hline $\begin{array}{l}\text { Kubota } \mathrm{TiB}_{2} \\
2.9 \mathrm{~g} \mathrm{Al} \\
\text { salt cover }\end{array}$ & E165 & 960 & 1 & $\begin{array}{l}\text { non wet or dewet, pickup of } \mathrm{Fe}, \mathrm{Ni} \text {, and } \mathrm{Si} \text { in } \\
\mathrm{Al}\end{array}$ \\
\hline $\begin{array}{l}\text { Eagle Picher } \\
\mathrm{TiB}_{2} \\
2.7 \mathrm{~g} \mathrm{Al} \\
\text { salt cover }\end{array}$ & E163 & 960 & 1 & $\begin{array}{l}\text { complete substrate coverage } \\
\text { spreading around edge of } \mathrm{TiB}_{2} \text { piece } \\
50 \text { microns of } \mathrm{GB} \text { penetration by } \mathrm{Al} \\
\text { unidentified second phase at interface }\end{array}$ \\
\hline $\begin{array}{l}\text { Eagle Picher } \\
\mathrm{TiB}_{2} \\
3.0 \mathrm{~g} \mathrm{Al} \\
\text { salt cover }\end{array}$ & E197 & 960 & 7 & $\begin{array}{l}\text { complete substrate coverage with evidence of } \\
\text { dewetting onset }\end{array}$ \\
\hline $\begin{array}{l}\text { Eagle Picher } \\
\mathrm{TiB}_{2} \\
2.9 \mathrm{~g} \mathrm{Al} \\
\text { salt cover }\end{array}$ & E172 & 960 & 24 & complete dewetting \\
\hline
\end{tabular}


The cross sections of the samples from the graphite-lined vacuum furnace wetting experiments showed little penetration of the Alcoa and Eagle Picher substrates after the $24 \mathrm{hr}$ and $2 \mathrm{hr}$ holds at $1025^{\circ} \mathrm{C}$. The results for the Eagle Picher and Alcoa substrates are therefore a more reliable record of the contact angle kinetics under these conditions.

Since there is extensive reaction and penetration of the Cercom and Kubota substrates with the $\mathrm{Al}$ drop, the macroscopic contact angles are misleading as was discussed earlier.

Titanium diboride is widely accepted by the Aluminum Industry to be completely wet by liquid aluminum. There are very few carefully-controlled wetting experiments that demonstrate this fact (Figure 5.3-5.4-6). Above $1000^{\circ} \mathrm{C}$ a spreading condition $\left(\theta=0^{\circ}\right)$ was obtained in vacuum wetting experiments of high-purity $\mathrm{Al}$ on a $100 \mathrm{~nm}$ thick coating of $\mathrm{TiB}_{2}$ that was deposited on an alumina substrate (Eustathopoulos and Cordurier 1985). The $1025^{\circ} \mathrm{C}$ vacuum wetting experiments of this study also demonstrated spreading on the Eagle Picher and Alcoa polycrystalline samples that were sintered to high density. Similar samples studied by Bardal et al. at $990^{\circ} \mathrm{C}$ had low, but finite contact angles. A wetting transition to a contact angle below $90^{\circ}$ at $870^{\circ} \mathrm{C}$ is cited by Eustathopoulos et al. 1985, but such a transition was observed by Rhee 1970 at $700^{\circ} \mathrm{C}$. In an unpublished study (Weirauch 1998) $\mathrm{TiB}_{2}$ was been shown to wet $\mathrm{TiB}_{2}$ at $760^{\circ} \mathrm{C}$ in a 1 atm $\mathrm{Zr}$-gettered argon atmosphere. It has also been shown that a stable contact angle is not reached after a $100 \mathrm{hr}$ hold. The wide scatter of the $\mathrm{TiB}_{2}$ wetting results are partially explained by the spreading kinetics for a given set of experimental conditions, and the time at which the sessile drop experiment was terminated. Al spreading kinetics from different wetting experiments are shown in Figure 5.3-5.4-13. 


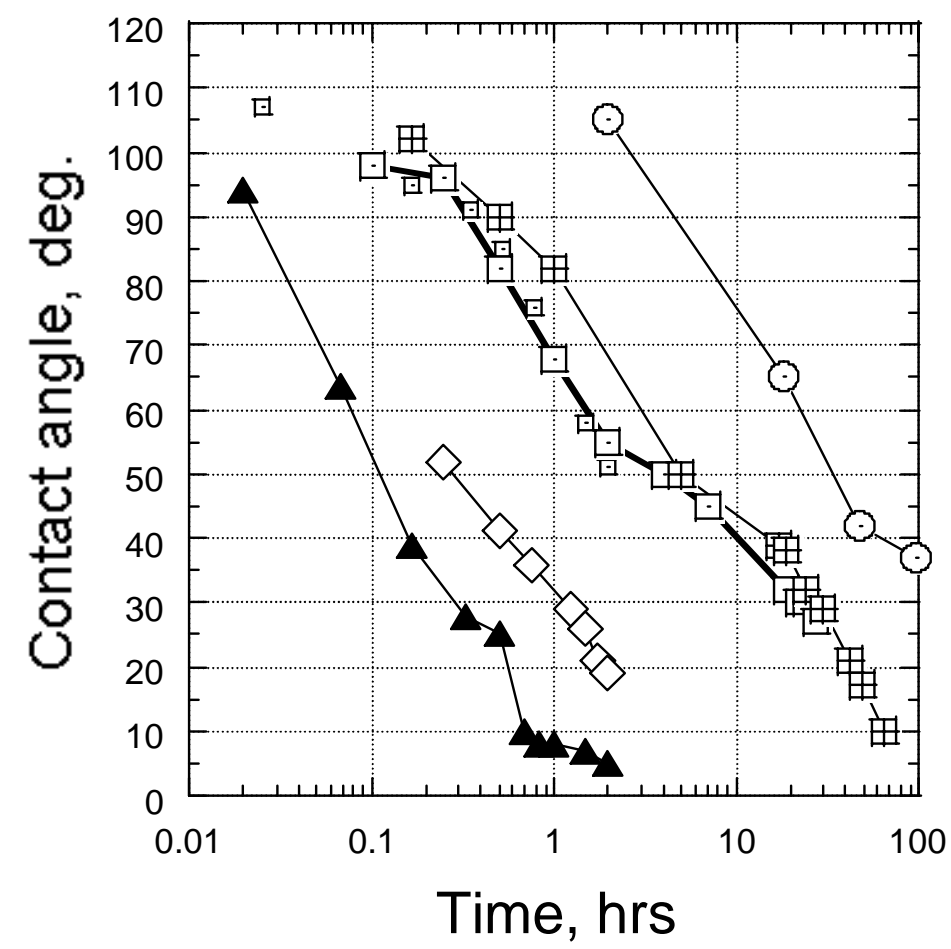

Triangles: This study, Eagle Picher $\mathrm{TiB}_{2} \mathrm{C}$ furnace $10^{-4}$ torr, $1025^{\circ} \mathrm{C}$

Diamonds: Weirauch et al, 1995 , Alcoa $\mathrm{TiB}_{2}$, quartz furnace $10^{-3.5}$ torr, $1085^{\circ} \mathrm{C}$

Squares: This study, Alcoa $\mathrm{TiB}_{2}, \mathrm{C}$ furnace $10^{-4}$ torr, $1025^{\circ} \mathrm{C}$

Circles: Weirauch, 1998 , Alcoa $\mathrm{TiB}_{2}, \mathrm{Zr}$ crucible $1 \mathrm{~atm} \mathrm{Ar}, 760^{\circ} \mathrm{C}$

\section{Figure 5.3-5.4-14 The spreading kinetics of $\mathrm{Al}$ on $\mathrm{TiB}_{2}$ under different experimental conditions.}

The slow spreading kinetics are attributed to the slow removal of oxide barriers from both the liquid aluminum drop and the titanium diboride substrate (Bardal et al., 1994). The oxygen partial pressures attained in the low oxygen experiments of this study are low enough to reduce $\mathrm{B}_{2} \mathrm{O}_{3}$, but not low enough for $\mathrm{TiO}_{2}$ or $\mathrm{Al}_{2} \mathrm{O}_{3}$ (Figure 5.3-5.4-13). 


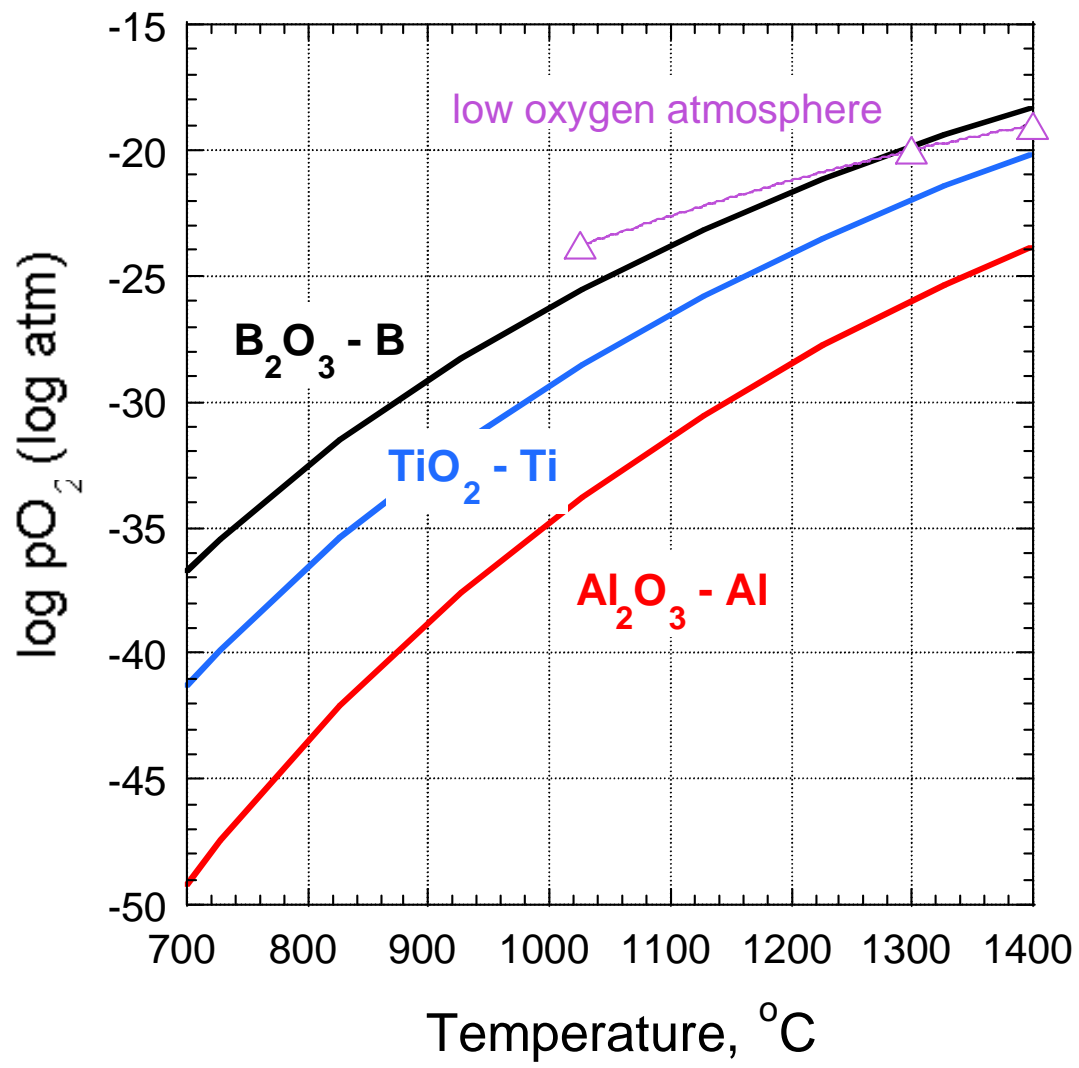

Figure 5.3-5.4-14 The oxygen level in the $1 \mathrm{~atm}$ wetting experiments compared to selected metal-oxide equilibria.

The measured $10^{-15.2}$ to $10^{-20}$ atm range of the oxygen partial pressures of the furnaces atmosphere approaches the equilibrium $\mathrm{pO}_{2}$ of $\mathrm{B} / \mathrm{B}_{2} \mathrm{O}_{3}$ at $1300^{\circ} \mathrm{C}\left(10^{-20} \mathrm{~atm}\right)$. While it is tempting to conclude that the slow spreading kinetics are controlled by reaction with a $\mathrm{B}_{2} \mathrm{O}_{3}$ layer on the titanium diboride surface, more work is required to characterize the oxide layers that form on these materials.

The kinetics of wetting $\mathrm{TiB}_{2}$ by liquid $\mathrm{Al}$ are greatly accelerated under a cryolitic salt cover. A spreading condition was observed in this study after a $2 \mathrm{hr}$ hold at $960^{\circ} \mathrm{C}$ under the Hall Cell bath, and it may have been achieved at shorter times. Watson and Toguri 1991 used radiographic techniques to track the $\mathrm{Al}$ spreading kinetics on hot-pressed $\mathrm{TiB}_{2}$ under a cryolitic melt cover. They observed a spreading condition within a few seconds at $980^{\circ} \mathrm{C}$. The spreading kinetics decreased as the carbon content of $\mathrm{TiB}_{2} / \mathrm{C}$ composites increased. It took 90 minutes for complete wetting to be reached at $1000^{\circ} \mathrm{C}$ under a salt cover for a $\mathrm{C}-\mathrm{TiB}_{2}$ composite containing $38 \mathrm{wt} . \% \mathrm{C}$.

The loss of sample mass from the Al drop under either vacuum conditions or a salt cover is a concern as it could affect the apparent contact angle kinetics. On real solid surfaces a contact angle hysteresis is anticipated with the highest value being the advancing contact angle $\left(\theta_{\mathrm{a}}\right)$ 
and the lowest the receding contact angle $\left(\theta_{\mathrm{r}}\right)$. If liquid mass is lost, and the drop perimeter is fixed, the angle will fall until $\theta_{\mathrm{r}}$ is reached (Watson and Toguri 1990). Further loss of mass will cause the contraction of the drop perimeter to maintain the contact angle at $\theta_{\mathrm{r}}$. In the vacuum wetting experiments on the Alcoa substrate (Figure 5.3-5.4-6) the drop perimeter was observed to advance up to approximately $24 \mathrm{hrs}$. Thereafter a slow retreat of the contact line was observed. A breakpoint in the wetting kinetic curves is observed at this time. At shorter times metastable $\theta_{\mathrm{a}}$ values are observed while after this time $\theta_{\mathrm{r}}$ is observed.

\section{3-5.4.4.5 Impurity Pickup in Al}

The growth of the oxide layer on the Al sessile drop interrupted the spreading process in the 1 atm low-oxygen experiments conducted at UMR. This resulted in drops with contact angle of 90 degrees or higher that didn't change during the hold at temperature. In other words, a solid-liquid interface was formed in these experiments, but rapid oxidation altered the liquidvapor surface. These experiments were useful in tracking the migration of impurities from the $\mathrm{TiB}_{2}$ substrate to the high-purity aluminum. Since the contact angles were high, the drop could be removed from the substrate and dissolved for analysis by inductively-coupled mass spectrometry (ICP-MS). The levels of the major impurities picked up from the Alcoa and Eagle Picher materials are shown in Figure 5.3-5.4-15. The fall in some levels with increasing time may reflect the errors inherrent in this procedure. The impurity levels in $\mathrm{Al}$ detected after an $8 \mathrm{hr}$ hold at $1025^{\circ} \mathrm{C}$ in the low-oxygen $1 \mathrm{~atm}$ experiments are shown in relation to the starting impurity levels in Figure 5.3-5.4-16. It is seen that certain impurities like $\mathrm{Fe}$ and $\mathrm{Cr}$ are more readily picked up $\mathrm{Al}$ than others $(\mathrm{W}, \mathrm{Nb}, \mathrm{Zr}$ ). The higher levels for the Eagle Picher $\mathrm{TiB}_{2}$ may also be influenced by the greater liquid-solid contact area that is associated with the lower contact angles for this material. More careful experimentation to control the contact area and drop mass is required to quantify this behavior. Nevertheless, if

sintering aids are to be used to produce dense $\mathrm{TiB}_{2}$ plates to be used as cathodes, the elements that are slower to be picked up may be preferred. 

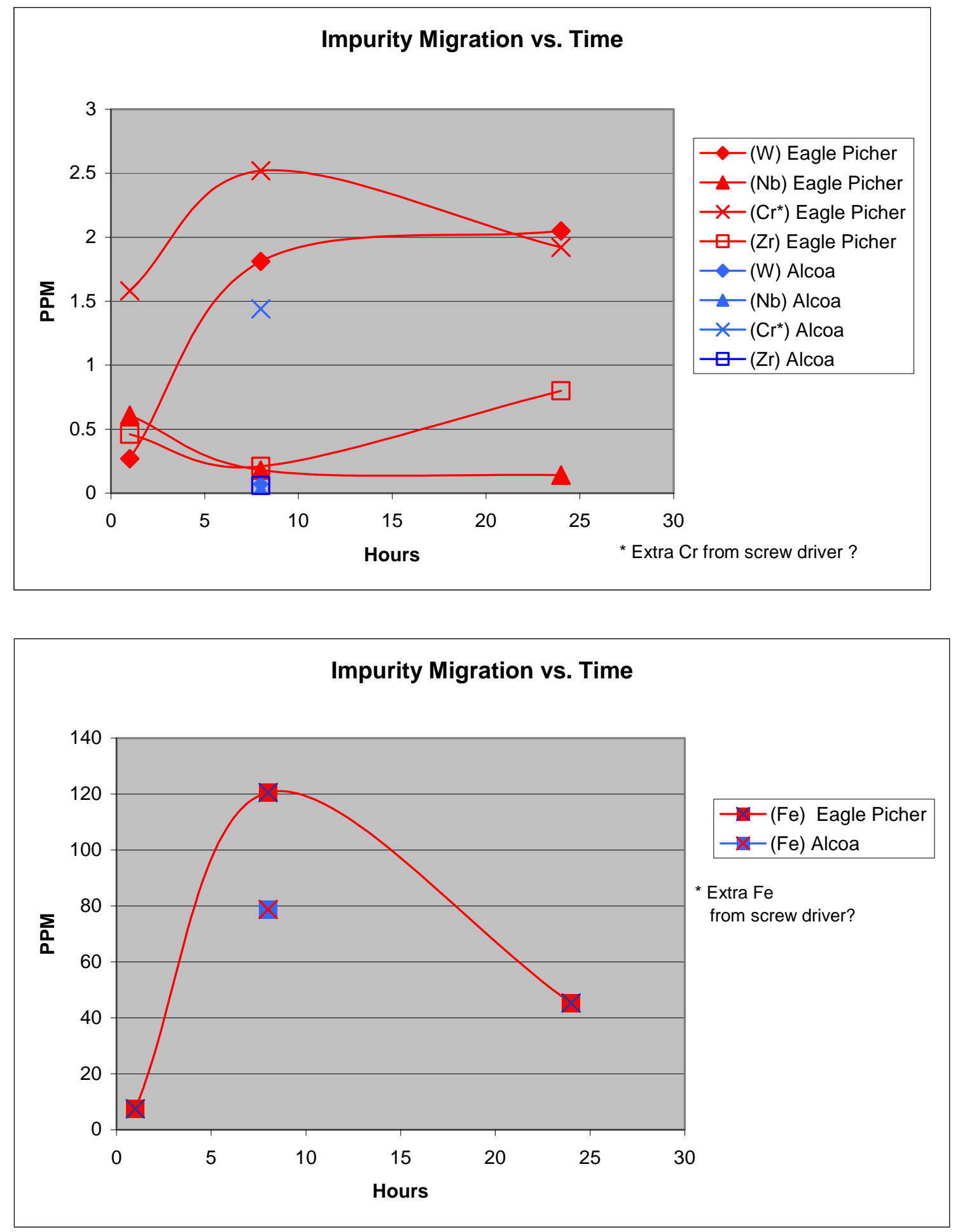

Figure 5.3-5.4-15 Impurity pickup in the Al sessile drops stranded on two $\mathrm{TiB}_{2}$ substrates at $1025^{\circ} \mathrm{C}, \mathrm{pO}_{2}=1.6 \times 10^{-24} \mathrm{~atm}$ 


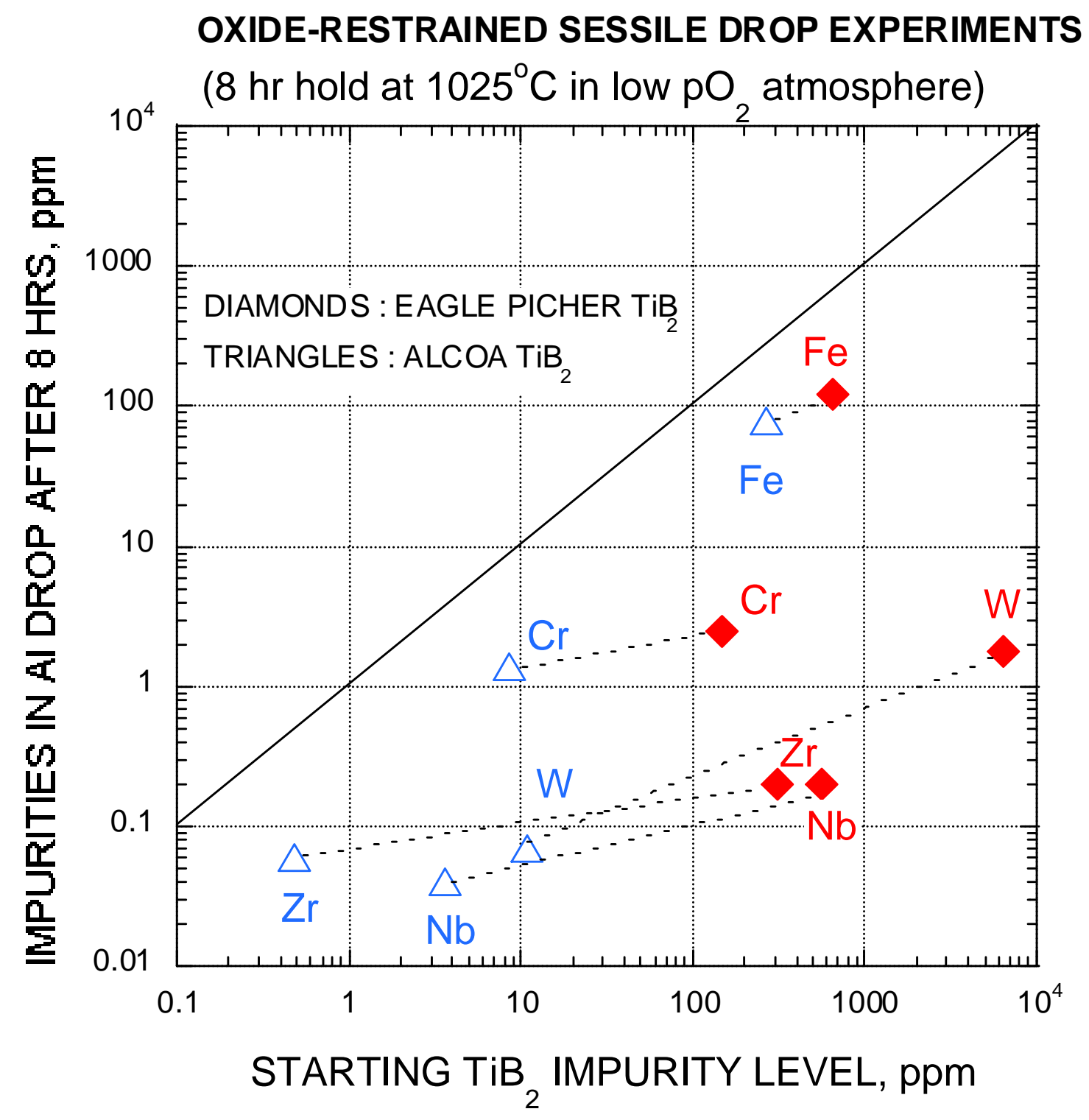

Figure 5.3-5.4-16 Impurity pickup in Al drops after 8 hrs in contact with two different $\mathrm{TiB}_{2}$ substrates at $1025^{\circ} \mathrm{C}$

\section{3-5.4.5 Conclusions}

1. Many characteristics of $\mathrm{TiB}_{2}$ materials will influence their wetting behavior by aluminum. Those examined in this study include $\mathrm{TiB}_{2}$ grain size, porosity, and impurity type and content.

2. It was not possible to reduce the oxygen content of the 1 atm hydrogen gas atmosphere low enough to prevent the rapid formation of an aluminum oxide layer on the aluminum sessile drop. At $1025^{\circ} \mathrm{C}$ and a $\mathrm{pO}_{2}$ of $1.6 \times 10^{-24}$ atm, the oxide layer constrained the drop spreading process, yielding artificially high contact angles. 
When the temperature was raised above $1300^{\circ} \mathrm{C}$, the wetting and spreading behavior expected for the dense, high-purity $\mathrm{TiB}_{2}$ was observed. The measured $10^{-15.2}$ to $10^{-20}$ atm range of the oxygen partial pressures of the furnaces atmosphere approaches the equilibrium $\mathrm{pO}_{2}$ of $\mathrm{B} / \mathrm{B}_{2} \mathrm{O}_{3}$ at $1300^{\circ} \mathrm{C}\left(10^{-20}\right.$ atm $)$. A more thorough characterization of the oxide layers that form on a given $\mathrm{TiB}_{2}$ substrate material is required to interpret the observed spreading behavior.

3. A wide range of wetting, spreading, and $\mathrm{TiB}_{2}$ penetration behavior was observed for the four substrates in $1025^{\circ} \mathrm{C}$ carbon vacuum furnace experiments. In order to distinguish between the wettability of different materials using the sessile drop technique, it is important to track the change in contact angle with time and establish that stable values have been attained. Arbitrary termination of the experiment after a constant hold time could interrupt the physicochemical interaction of the liquid drop with different solid substrates at different stages of the process.

4. The dense, high-purity Eagle Picher $\mathrm{TiB}_{2}$ was strongly wet by $\mathrm{Al}$ and achieved a spreading condition (contact angle $=0^{\circ}$ ) within $2 \mathrm{hrs}$ at $1025^{\circ} \mathrm{C}$.

5. The spreading kinetics of the dense Alcoa $\mathrm{TiB}_{2}$ was slowed by the presence of 2.2 wt.\% $\mathrm{C}$ and only attained a spreading condition after $65 \mathrm{hrs}$ at $1025^{\circ} \mathrm{C}$.

6. The true wetting behavior of the Kubota and Cercom materials was not revealed by the contact angle measurements. The $28.5 \%$ apparent porosity of the Cercom $\mathrm{TiB}_{2}$ resulted in substrate penetration that affected the contact angle results. Strong reaction between $\mathrm{Al}$ and the $5.5 \mathrm{wt} . \% \mathrm{Ni}$ of the Kubota $\mathrm{TiB}_{2}$ resulted in an expansion of the substrate that affected the measured contact angle.

7. Wetting experiments conducted under a Hall Cell salt cover confirmed the wetting results obtained under vacuum in a carbon furnace for the Eagle Picher and Alcoa $\mathrm{TiB}_{2}$ samples. The wetting kinetics are greatly accelerated under the salt cover and the effect of oxide dissolution in the molten salts apparently plays a role. Very different results (dewetting) were obtained for the Cercom and Kubota materials suggesting that chemical and physical interaction with the salt will affect the reaction and penetration behavior of impure or porous $\mathrm{TiB}_{2}$.

8. Stable liquid-Al/solid $\mathrm{TiB}_{2}$ couples were produced in the 1 atmosphere low oxygen experiments that were used to track impurity migration from the solid to the liquid. It is seen that certain impurities like $\mathrm{Fe}$ and $\mathrm{Cr}$ are more readily picked up $\mathrm{Al}$ than others $(\mathrm{W}, \mathrm{Nb}, \mathrm{Zr})$. Further experimentation with careful control of the contact area and drop mass is required to quantify this behavior. Nevertheless, if sintering aids are to be used to produce dense $\mathrm{TiB}_{2}$ plates to be used as cathodes, the elements that are slower to be picked up may be preferred. 
9. The molten salt attacks $\mathrm{TiB}_{2}$ grain boundaries. The order of wetting (Al vs. salt) will need to be addressed in future studies as it may influence the long-term stability of the cathode material.

\section{3-5.4.6 Recommendations for Future Work}

1. A technique for evaluating the long-term chemical stability and wetting behavior of candidate $\mathrm{TiB}_{2}$ cathode materials under aluminum electrolysis conditions needs to be developed. This would contribute to a better understanding of the effect of the electrolyte on the critical chemical and physical interactions occurring between $\mathrm{Al}$ and $\mathrm{TiB}_{2}$ in practical cathode operating conditions.

2. The performance of dense plates of $\mathrm{TiB}_{2}$ sintered with refractory metal additives should be assessed in vertical cell electrolysis tests. $\mathrm{TiB}_{2}$ with a reduced level of $\mathrm{Ni}$ should also be considered as $\mathrm{Ni}$ drives spreading on $\mathrm{TiB}_{2}$ surfaces.

3. The wetting behavior of porous $\mathrm{C}-\mathrm{TiB}_{2}$ cathode materials by $\mathrm{Al}$ should be thoroughly characterized.

4. The effect of sample porosity and reactive impurities on wetting and penetration kinetics merits further study.

5. More attention needs to be paid to the nature of the oxides that forms on sintered $\mathrm{TiB}_{2}$ materials. This needs to be considered in the context of chemical reactions that occur with both molten salt and molten aluminum.

\section{3-5.4.7 References}

A. Bardal, K. Nord-Varhaug, J. H. Ulvensoen, and E. Skybakmoen, Interfacial Microstructure and the Wettability of Titanium Diboride by Liquid Aluminium, pp. 93-97 in Proc. First International Conference on High Temperature Capillarity, N. Eustathopoulos (ed.), Bratislava, Slovakia, 1994.

H. R. Baumgartner and R. A. Steiger, Sintering and Properties of Titanium Diboride Made from Powder Synthesized in a Plasma-Arc Heater, J. Amer.Ceram.Soc. 67 [3] 207-212 (1984).

N. Eustathopoulos and L. Coudurier, Wettability and Thermodynamic Adhesion in the AlAl2O3 System: Effect of $\mathrm{a} \mathrm{TiB}_{2}$ or TiN Coating, Ann. Chim. Fr. (Paris) 10 [1] 1-6 (1985).

C. Mroz, Titanium Diboride, Ceram. Bull. 79 [6] 55 (2000).

P. D. Ownby, K. W. Li and D. A. Weirauch, Jr., High-Temperature Wetting of Sapphire by Aluminum, J. Am. Ceram. Soc., 74 [6] 1275-81 (1991). 
S. K. Rhee, Wetting of Ceramics by Liquid Aluminum, J. Amer. Ceram. Soc. 53 [7] 386-389 (1970).

K. D. Watson and J. M. Toguri, The Wettability of Carbon/TiB 2 Composite Materials by Aluminium in Cryolite Melts, Metall. Trans. B, 22B:617-621(1991).

D. A. Weirauch, Jr., A Reappraisal of Wetting in the System $\mathrm{Al}^{-} \mathrm{Al}_{2} \mathrm{O}_{3}$ from $750-1000^{\circ} \mathrm{C}$, Ceramic Microstructures'86, Role of Interfaces, Materials Science Research Vol. 21, J. A. Pask and A. G. Evans, eds., Plenum Press, NY, 329-339, 1988.

D. A. Weirauch, Jr., W. M. Balaba, and A. J. Perrotta, Kinetics of the Reactive Spreading of Molten Aluminum on Ceramic Surfaces, J. Mater. Res. 10 [3] 640-650 (1995).

D. A. Weirauch, Jr., The Wetting of Ceramic Solids by Liquid Aluminum at $1033 \mathrm{~K}$ and 1 atm Total Pressure, Alcoa Technical Center Report No. 98-004, 1998.

\section{List of Figures}

1. SEM views of fracture surfaces of the $\mathrm{TiB}_{2}$ Samples of this study

2. The UMR low $\mathrm{O}_{2}$ sessile drop furnace.

3. Apparatus for $\mathrm{pO}_{2}$ measurement

4. The ATC carbon furnace vacuum wetting apparatus.

5. The wetting of dense polycrystalline $\mathrm{TiB}_{2}$ by $\mathrm{Al}$ under vacuum conditions

6. The wetting of various $\mathrm{TiB}_{2}$ materials by $\mathrm{Al}$ as revealed by carbon vacuum furnace experiments.

7. Secondary spreading observed around the drop perimeter of a wetting experiment of $\mathrm{Al}$ on Eagle Picher $\mathrm{TiB}_{2}$ after cooling to room temperature.

8. Alcoa cross section

9. Cercom cross section

10. Kubota cross section

11. Dewetting of $\mathrm{Al}$ from $\mathrm{TiB}_{2}$ under a Hall Cell cover salt.

12. The spreading kinetics of $\mathrm{Al}$ on $\mathrm{TiB}_{2}$ under different experimental conditions.

13. The $\mathrm{pO}_{2}$ vs. temperature range of the low oxygen wetting experiments compared to selected metal-oxide equilibria.

14. The kinetics of Al drop impurity pickup.

15. Al drop impurity level after $8 \mathrm{hrs}$ at $1025^{\circ} \mathrm{C}$ vs. starting impurity level. 


\section{List of Tables}

1. Chemical Impurities in the $\mathrm{TiB}_{2}$ Samples of This Study

2. Density of the $\mathrm{TiB}_{2}$ Samples of This Study

3. Summary of the UMR Wetting Experiments

4. Chemical Stability the $\mathrm{TiB}_{2}$ Samples Under Different Conditions 
Attachment: Survey of $\mathbf{T i B}_{\mathbf{2}}$ Vendors Conducted by MRD

\begin{tabular}{|l|l|}
\hline Eagle Picher & Comments \\
\hline Boron Department & $\begin{array}{l}\text { Studied hot pressed TiB2 substrates from } \\
\text { this company } \\
\text { 798 Hwy 69A }\end{array}$ \\
Quave chemistry and cost for smaller hot pressed TiB2 \\
Contact: Larry Addington \\
Phone 918 673 2201
\end{tabular}

\begin{tabular}{|c|c|}
\hline Ceradyne Inc. & Comments \\
\hline 3169 Redhill Ave. & Exchanged e-mail, phone conversations and faxes \\
\hline Costa Mesa, Ca 92626 & $\begin{array}{l}\text { Chemistry and cost for biggest hot pressed TiB } 2 \text { available. } \\
\text { Have quote for smaller tile for analysis. }\end{array}$ \\
\hline Phone 7145490421 & Contact: Dennis Hoskins ext 201 \\
\hline
\end{tabular}

\begin{tabular}{|c|c|}
\hline GoodFellow Corporation & Comments \\
\hline 800 Lancaster Avenue & Currently have quote from them - very expensive \\
\hline Berwyn, PA 19312-1780 & No chemistry available \\
\hline Phone 18008212870 & $\begin{array}{l}\text { Quote by FAX : REF \#Q245906 } \\
\text { www. Goodfellow.com Prices for smaller samples also } \\
\text { on web page }\end{array}$ \\
\hline
\end{tabular}

\begin{tabular}{|l|l|}
\hline \multirow{2}{*}{ Kubota Corporation } & Comments \\
\cline { 2 - 2 } & $\begin{array}{l}\text { Exchanged e-mail } \\
\text { e-mail contact: "hiroshi-y@ kubota.co.jp" }\end{array}$ \\
\hline Toshiba Ceramics & Comments \\
\hline $\begin{array}{l}\text { Nishi-Shinjuku Kimuraya Bldg. } \\
\text { 5-25, Nishi-Shinjuku 7-chome, Shinjuku-ku } \\
\text { Tokyo 160-0023, Japan }\end{array}$ & $\begin{array}{l}\text { Sent e-mail with no response } \\
\text { Sent another e-mail with no response. }\end{array}$ \\
\hline
\end{tabular}




\begin{tabular}{|l|l|}
\hline Cercom Inc. & Comments \\
$\begin{array}{l}\text { 1960 Watson Way, PO Box 70 } \\
\text { Vista, CA 92083 }\end{array}$ & $\begin{array}{l}\text { Contact: Richard Palicka 1-760-727-6209 Ext } 18 \\
\text { Have starting chemistry, } \\
\text { This material included in wetting studies }\end{array}$ \\
\hline
\end{tabular}

\begin{tabular}{|l|l|}
\hline Advanced Refractories Technologies, Inc. & Comments \\
\hline $\begin{array}{l}699 \text { Hertel Ave. } \\
\text { Buffalo, New York } 14207\end{array}$ & $\begin{array}{l}\text { Contact: Christopher Hailand 1-716-875-4091 } \\
\text { e-mail: chailand@ art-inc.com } \\
\text { Sending chemistry and free samples for wetting studies. } \\
\text { Last contact: 7/14/2000 }\end{array}$ \\
\hline
\end{tabular}

\begin{tabular}{|l|l|}
\hline Kyocera Industrial Ceramics Corp. & Comments \\
\hline 5713 E. Fourth Palin Blvd. & $\begin{array}{l}\text { Contact: Dr. Edwin Kraft } 13607506147 \\
\text { They do not manufacture TiB2. }\end{array}$ \\
\hline
\end{tabular}


TASK 9: BENCH TEST OF ANODE METAL PHASE, THIN CATHODE PLATES, ALUMINA OPERATING RANGE, CATHODE CONNECTIONS, AND SIDE WALL BARRIER

Anodes with varying metal phase contents and adders will be tested to provide the best choice based on corrosion rates, aluminum impurity levels, and electrical conductivity. A favored thin cathode plate concept will be included in the bench cell design. This test will also help select an advantageous alumina operating range, a workable vertical cathode connection to the metal sump and an improved side wall barrier. The best experimental plan will be pre-determined with statistical software using estimated corrosion rates to determine the tradeoff between duration of a test and number of tests, repetitions, and variables such as anode metal phase content and cathode size. Two or even three smaller tests with less variables may be substituted as indicated by on-going experimental results and updated experimental plans.

\subsection{Design, Procure, and Build Cell}

Minor design changes will be required to incorporate vertical cathode connection concepts, a barrier improvement, and thin cathode plates.

\subsection{Operate Test}

The anode electrolysis area (including a reasonably constant anodic current density), the aluminum cathode surface area, bath level, the ratio of $\mathrm{NaF}$ to $\mathrm{AlF}_{3}$, and the alumina concentration are critical parameters, which must be controlled to selected values. The resistance of anodes, cathode plates and cathode connections will be determined as a function of time. Estimates of current efficiency and sludge formation will be made.

\subsection{Autopsy Unit, Analyze data}

Anode corrosion rates and operating voltages will be evaluated using a statistical package to determine statistically significant differences. Analyses of metal and bath will be done to determine impurity levels. Estimates of current efficiency, cathode wetting and sludge formation will be made. The unit will be examined to determine bath penetration of the barrier and graphite crucible and deterioration of cathode plates, cathode connections, and critical materials. Chemical analyses and SEM/EDAX analyses will be performed on autopsy samples.

In order to study critical features of cells with vertical arrays of inert anodes and stable cathodes, large bench scale cells were designed and built which were typically operated at 40 amps compared to 7.5 amps for pencil anode cells used primarily for material tests. Current densities ranging from 0.2 to $0.5 \mathrm{amp} / \mathrm{cm}^{2}$ were the same for both types of cells. These large bench cells could incorporate either vertical or horizontal electrode configurations. Several of these cells with vertical electrodes - designated VP1 to VP14 - were tested and current efficiencies ranging from $25 \%$ to $66 \%$ were measured. These values were lower and more variable than expected even considering that adverse conditions such as sludging were sometimes deliberately included in the test. At least some of this variability appeared to be 
due to differences in the wetting characteristics of the $\mathrm{TiB}_{2}-\mathrm{G}$ vertical plates based on examination of the cathodes after the tests. The vertical cathode geometry and cell design details were also considered important factors.

In pencil anode cells operating at 7.5 amps, we typically see $90-93 \%$ current efficiency. The pencil cells have a horizontal aluminum sump as the cathode. A large bench cell was built to parallel as closely as possible the geometry used in the pencil anode experiments. The only significant difference between this cell (designated VP18) and the pencil anode experiments was the anode size. The anode used was a typical $40 \mathrm{amp}$ anode, approximately $1 "$ thick by $2 "$ wide by 9 " tall. It was immersed to $6.1 \mathrm{~cm}$, the standard immersion for the pencil anodes. Current efficiency was excellent at $92 \%$. This run proved that high current efficiency can be attained in the $40 \mathrm{amp}$ cell when the cathode is configured in a horizontal position.

The next three 40 amp cells (VP19,VP20, and VP21) had vertical $\mathrm{TiB}_{2}-\mathrm{G}$ plates as shown in Figure 5.3-9-1 with the dimensions correct for VP21. Current efficiencies for this group ranged from $65 \%$ to $77.5 \%$ which were better than previous $40 \mathrm{amp}$ cell tests with vertical plates but inferior to the horizontal cathode test at $92 \% \mathrm{CE}$. The vertical plates were directly immersed in the horizontal metal pool at the bottom of the cell. Thus there was no problem with a continuous flow of metal off the cathode plates into the metal pool. Previous runs with the vertical geometry had sloped regions leading to the metal pad. These plates were also pre-wet with molten aluminum. VP21 had the low value at $65 \%$ but it also had the greatest interfacial area (shadow) between anode and cathode. The interfacial height was 3.5 inches for VP21 versus 1.5 inches for VP19 and VP20. The cathode for VP21 was also closer to the bath surface - within 0.5 inches compared to 1 inch for the other two tests. Both a higher shadow and proximity to the bath air interface are expected to lower current efficiency. For VP21, the anode was in contact with the Monofrax brick as shown in figure 5.3-9-1 while for VP19 and VP20, the anodes were 1 inch above the brick. This gap may have changed some of the bath flow patterns in the cell, reducing the interaction between the down flowing metal and the up flowing bath. Less interaction might mean less reaction between soluble $\mathrm{Al}$ and oxygen -and higher current efficiency. 


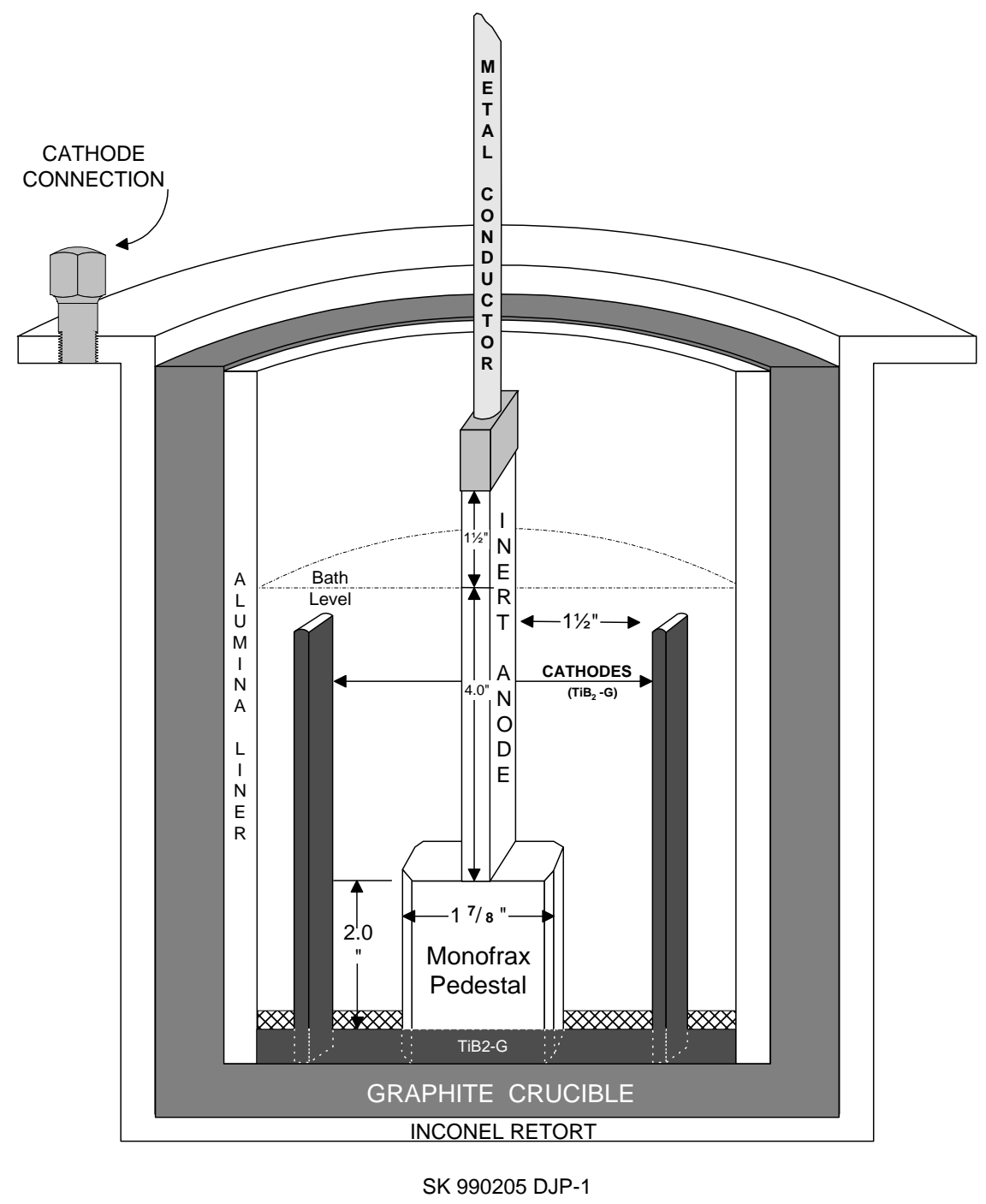

Figure 5.3-9-1 Bench scale vertical plate cell with two cathodes and one anode. 
Figure 5.3-9-2 shows the current efficiency results for all the large bench tests with vertical cathodes that were operated for sufficient time to obtain adequate measurements.

Bench Tests - Vertical Electrode Concept

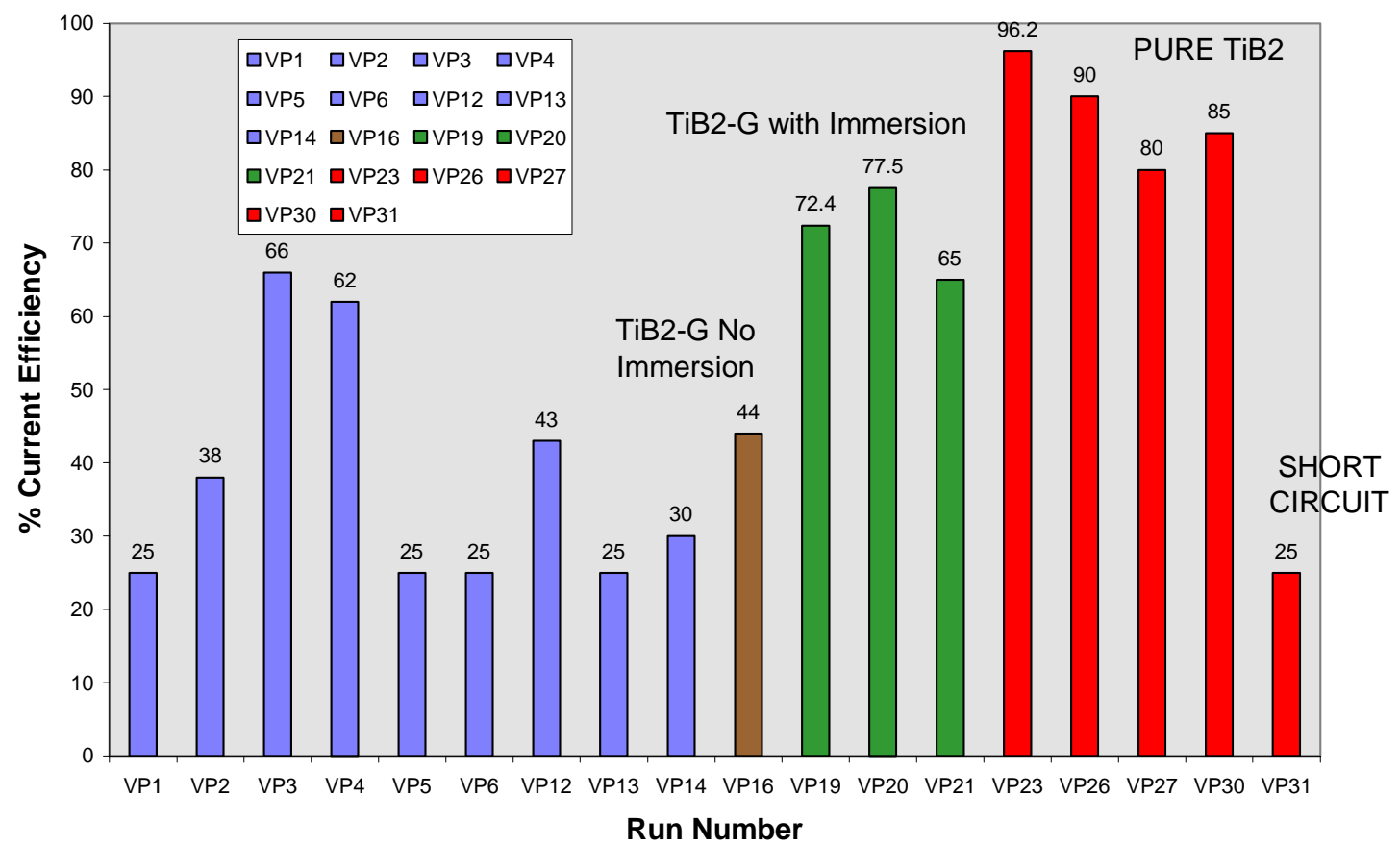

Figure 5.3-9-2 Current efficiency results for various bench vertical plate experiments.

Two vertical bench tests (VP23 and VP26) achieved high current efficiencies of $90.5 \%$ and $96.2 \%$, respectively by using pure TiB2 cathode plates instead of TiB2-G which had been used in all previous tests. These plates were not pre-wet with aluminum and had a 2.5 inch interfacial height with the anode. Aluminum wetting of the TiB2-G material has been inconsistent from sample to sample and sometimes on one sample.

After these results, the cell geometry was changed to a single central cathode flanked by two anodes. This eliminates very low current density, cathode areas located on the back of the cathode plates- away from the major electrolysis region. Runs VP27 and VP30 also utilized pure TiB2, were not pre-wet and had a 2.5 inch and 4.0 inch shadow, respectively. The current efficiencies were lower at $80 \%$ and $85 \%$, respectively, probably because a poor connection in the anodes led to poor current distribution and overheating of the anodes.

A bench cell with two vertical anodes and a centered vertical cathode (VP31) was then tested with a 6 in. interface or "shadow" between them. This was the first test at this shadow height which is prototypical of commercial cell concepts with vertical electrodes. Two pure $\mathrm{TiB}_{2}$ plates had to be joined together to achieve the required height. The $\mathrm{TiB}_{2}$ cathode horizontal joint did not drain aluminum metal and caused a short circuit resulting in a poor CE $~ 25 \%$. 
The anode also had a novel connection which seemed to improve with time, resulting in a lower cell voltage.

VP32 operated at 60 amps with a six inch shadow between two vertical anodes and a central cathode without joints as shown in Figure 5.3-9-3. A single thin (0.20 inch) CerCom $\mathrm{TiB}_{2}$ plate served as the cathode. A new vertical anode connection was used. This cell achieved a respectable $76 \%$ current efficiency and a low voltage operation of 3.8 volts. The metal sump was too small and metal overflowed causing some shorting near the end of the test, which may have reduced the current efficiency. 


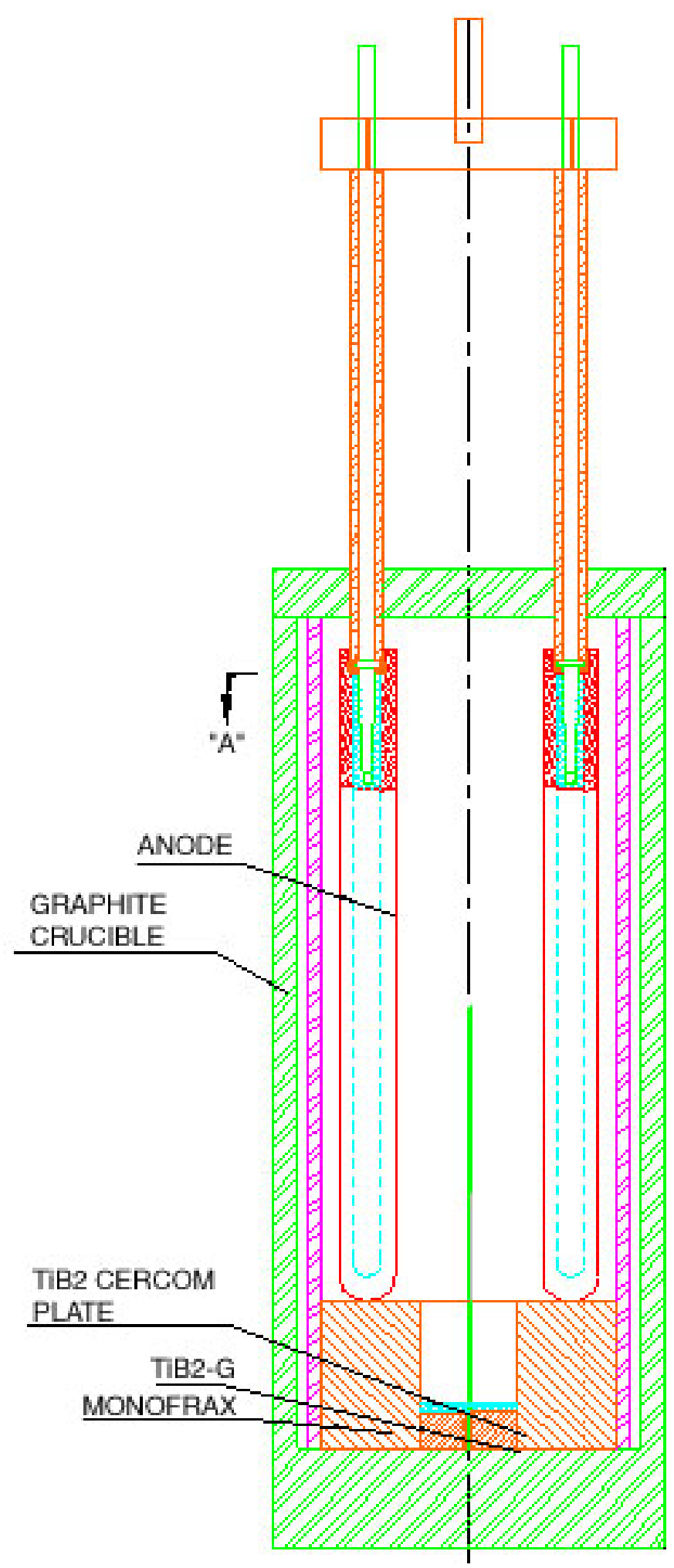

Figure 5.3-9-3 Bench scale vertical plate cell with one cathode and two anodes. 
These results provide reasonable confidence that high current efficiencies can be achieved with vertical electrodes at interfacial distances of 2.5 inches and anode-cathode spacing of 1.5 inches. Further tests must demonstrate current efficiencies greater than $90 \%$ at interfacial distances of at least 6 inches. Tall (at least 9 inches), relatively pure $\mathrm{TiB}_{2}$ plates are needed for future prototypical tests. Several vendors were identified and tall plates purchased for 60300 A tests. Plates of sufficient height were received from both Cercom and Kubota, and one was used in VP32. In addition, CerCom has supplied some $12 \times 12 \times 0.06$ and $12 \times 12 \times 0.22$ inch plates from inventory and can produce $18 \times 18 \times 0.25$ inch plates. These are sufficiently large for 2000 amp pilot cell runs. Wetting characteristics of these new materials need to be established.

TASK 11: BENCH TEST OF ANODE CERAMIC PHASE, ADVANCED CATHODE PLATES, IMPROVED LID DESIGN, IMPROVED ANODE CONNECTIONS IN A CELL MODIFIED TO REDUCE OR REMOVE SLUDGE (ORIGINAL) Anodes, which have been previously screened, will include ceramic phase changes that could reduce the corrosion rate or reduce problem impurities in the metal produced. These will be tested in this cell to help select the best performers. This test will also include advanced cathode plate technology from the candidates developed under Task 5.

\subsection{Bench Test of Horizontal Anode Designs (Revised) The original Task 11 was not appropriate for the work required. This task tested different connection schemes in electrolysis cells for bench scale horizontal anodes to permit the selection of a design or designs for the pilot cell.}

HP1, Horizontal Plate, was our first attempt to run a bench cell with a horizontal plate anode. A $40 \mathrm{amp}$ anode was cut in half to 2" x 4" x 1". Two spots on the large surface were reduced with carbon to permit two nickel rods (already attached to a nickel plate) to be diffusion welded to the anode. The diffusion weld was performed. An inconel connector rod was welded to the upper nickel plate. This anode was then installed in a bench electrolysis cell. After 36 hours the anode fell off. Upon autopsying the cell, the anode had separated from the rods at the diffusion weld.

HP2, Horizontal Plate \# 2, was the second run utilizing a horizontal plate anode. Two spots were again reduced on the large surface to permit two nickel rods to be attached by diffusion welding. The diffusion welding procedure was modified slightly increasing the weight on the upper plate to try to improve the contact and thus improve the diffusion weld. The anode again disconnected from the nickel rod after 28 hours. In this case, part of the reduced metal zone was actually pulled out of the anode, indicating that the diffusion weld was stronger than the reduced metal zone. This initiated efforts to connect the rod to the plate via mechanical means rather than just a diffusion weld to the reduced zone. 
HP3 was the third attempt using a redesigned connector bar structure. This structure involves a mechanical support based on gripping a ledge machined into the side of the anode. This anode was successfully run for 95 hours. There were some operational problems due to high heat losses up the more massive metal connector rod and pipe. The heat losses may have been accentuated by the location of the cell high in the furnace.

Horizontal anode run HP4 was run using the same redesigned connector bar structure as in run HP3, with the objective of testing the pressed-fit electrical connection. The anode current density was lowered to $0.5 \mathrm{~A} / \mathrm{cm}^{2}$. The anode connection performed well for the 72 hour run, with no voltage problems. The copper foil used at the anode-metal interface to improve the connection was intact at the end of the run and adhered to the anode. As an additional data point, the metal parts were coated with a plasma-sprayed aluminum oxide coating. This coating provided substantial, but not complete, protection of the Inconel assembly.

Subsequent tests of aluminum oxide and nickel ferrite plasma-sprayed coatings were performed on small inconel test coupons. Coatings were applied on substrates at ambient, 500 and $1000^{\circ} \mathrm{C}$. Exposure to $1350^{\circ} \mathrm{C}$ in air revealed good performance of the nickel ferrite, but bubbling and spalling of the alumina upon cooling. Exposure to bath vapors, however, revealed severe bubbling and cracking of the nickel ferrite, while the alumina coatings were intact, but again, spalled upon cooling. The decision was to continue to use the alumina coatings for future bench and pilot tests, while continuing to search for improved coatings. A poured-metal connection between the inert anode and a metal stub was investigated as an alternative anode connection. A small anode was produced using a poured $\mathrm{Cu}-\mathrm{Ni}$ metal interface, and was evaluated. A poured cast iron connection was tried.

\section{Task 11.2 - Horizontal Cell Pilot Test (Revised)}

Again, the original task was inappropriate. This task investigated the operation of a large pilot cell with inert anodes arranged in horizontal plates facing a molten aluminum cathode.

Rebuild for the horizontal pilot was completed. An interior cavity design with a $\mathrm{TiB}_{2}-\mathrm{G}$ lower lining and with Monofrax lining the upper sidewalls was utilized. A proprietary Alcoa $\mathrm{TiB}_{2}$ paint was used as a cement by altering the composition. The paint is a Ti-B-organic vehicle paint. By reducing the vehicle (increasing the Ti and B powders), the paint gets thicker and will act as a cement. We used the "cement" to bond the $\mathrm{TiB}_{2}-\mathrm{G}$ plates to the graphite substrate. An anode design with four horizontal plate anodes, each roughly 6" by 12 " by 2 " provided enough anode area to run at $1000 \mathrm{amps}$ at $0.6 \mathrm{amps} / \mathrm{cm}^{2}$. The cathode connector bars were slightly re-designed to utilize $\mathrm{TIB}_{2}-\mathrm{G}$ rods as the lower end connection to the metal pool. The graphite block for the bottom of the cell was designed with a metal sump to permit easier metal tapping. The cathode was the horizontal molten Al surface. There were no vertical plate cathodes.

Four feeders were utilized to ensure better alumina feed control. 
The superstructure was completed and set in place. Minor changes to several lid components were made. Plates were manufactured and coated to protect the bottom side of the anodes during heatup. Upper inner lids were also manufactured. The interior of the cell, including the $\mathrm{TiB}_{2}$ plates, the Monofrax sidewalls and the $\mathrm{Al}$ plate to protect the $\mathrm{TiB}_{2}$ were all installed. The cathode rods were built and baked out.

Feeding problems were apparent almost immediately. The crust breakers were not able to keep open a large enough area between the anodes to allow the feed to fall into liquid bath and dissolve into the bath. The bath stuck to the crust breaker rods and eventually plugged the bottom of some of the feed tubes. An attempt to hand feed the cell produced significant sludging due to localized high alumina concentrations. The crust breakers were moved to an external tube outside the feeder tubes to try to solve the plugging problem. Manual crust breaking was attempted, but this applied too much force to the anodes. The keyways on anodes 2 and 3 broke causing those two anodes to fall into the metal pad. No thermite reaction ocurred when the anodes fell into the molten aluminum metal pool.

The remaining anodes were relocated into positions 2 and 3 and DC electrolysis was attempted again. The feed dissolved into the bath when the bath temperature was $990^{\circ} \mathrm{C}$. Attempts to lower the bath temperature to the target operating temperature of $965-975^{\circ} \mathrm{C}$ invariably led to crust formation. The feed would pile up on the bath necessitating manual crust breaking. Metal levels increased confirming metal production. Sludge was removed from under the anodes by sweeping with a bent rod. A large mass eventually formed on the bottom of the east anode. When that mass was dislodged, it was observed that a corner of the anode had broken off. DC was stopped and the anodes removed. The cell was on DC for over nine days at current levels between 220 amps and 425 amps at voltages of $4.2 \mathrm{~V}$ to 6.0 V.

Two new anodes were installed slowly to minimize thermal shock. Minimizing temperature increases to $100^{\circ} \mathrm{C} /$ hour led to installation times of approximately 10 hours (room temperature to $960^{\circ} \mathrm{C}$ ). Both anodes were successfully installed with no apparent damage. These anodes had substantial insulation packs stacked on top of each anode to try to minimize heat loss and to maximize the temperature of each anode. The anode connector rods were designed differently. One was a pipe with a separate internal heater connected to its own power supply for heat input control. The second had a reduced diameter shaft to try to heat the rod by increased IR heating. The pipe with a heater worked slightly better with a higher temperature on the top surface of the anode $\left(930^{\circ} \mathrm{C}\right.$ versus $\left.910^{\circ} \mathrm{C}\right)$.

Additionally, at the same time the new anodes were installed, new subset lids were installed with more insulation to keep more heat in the cell to minimize crust formation. The combination of anode insulation and the insulation in the subset lids did help the thermal balance which manifested itself in a smaller temperature differential between the graphite crucible and the bath temperature. Where this difference had been running $90^{\circ} \mathrm{C}$, it dropped to $50^{\circ} \mathrm{C}$. Power supply problems initially made it impossible to run the DC power at 440 amps. Once the power supply was fixed, we were able to increase the current to 
440 amps. With the increased heat input under the anodes, crusting decreased and operations became much easier.

\section{Task 11.3 - Autopsy Unit, Analyze Data}

Anode corrosion rates and operating voltages will be evaluated using a statistical package to determine statistically significant differences. Analyses of metal and bath will be done to determine impurity levels. Estimates of current efficiency, cathode wetting and sludge formation will be made. The unit will be examined to determine bath penetration of the barrier and graphite crucible and deterioration of cathode plates, cathode connections, and critical materials. Chemical analyses and SEM/EDAX analyses will be performed on autopsy samples.

The cell was autopsied after being shutdown on 1999 June 05. Probing during operation had indicated that there was severe attack on the Monofrax (fused cast alumina) used as the sidewall material. This was confirmed during the autopsy as the Monofrax just above the lower $\mathrm{TiB}_{2}$ sidewall was completely gone. The Monofrax was initially 1.5 inches thick and roughly 1-2 inches of height were missing. The graphite crucible behind the Monofrax was reacted from 1 to 3 inches deep, probably by oxygen gas produced at the anodes. These reacted volumes were largest to the north and south of each anode, probably due to the proximity of the anode to the wall at those points (the anode to wall gap was only 1 inch). 


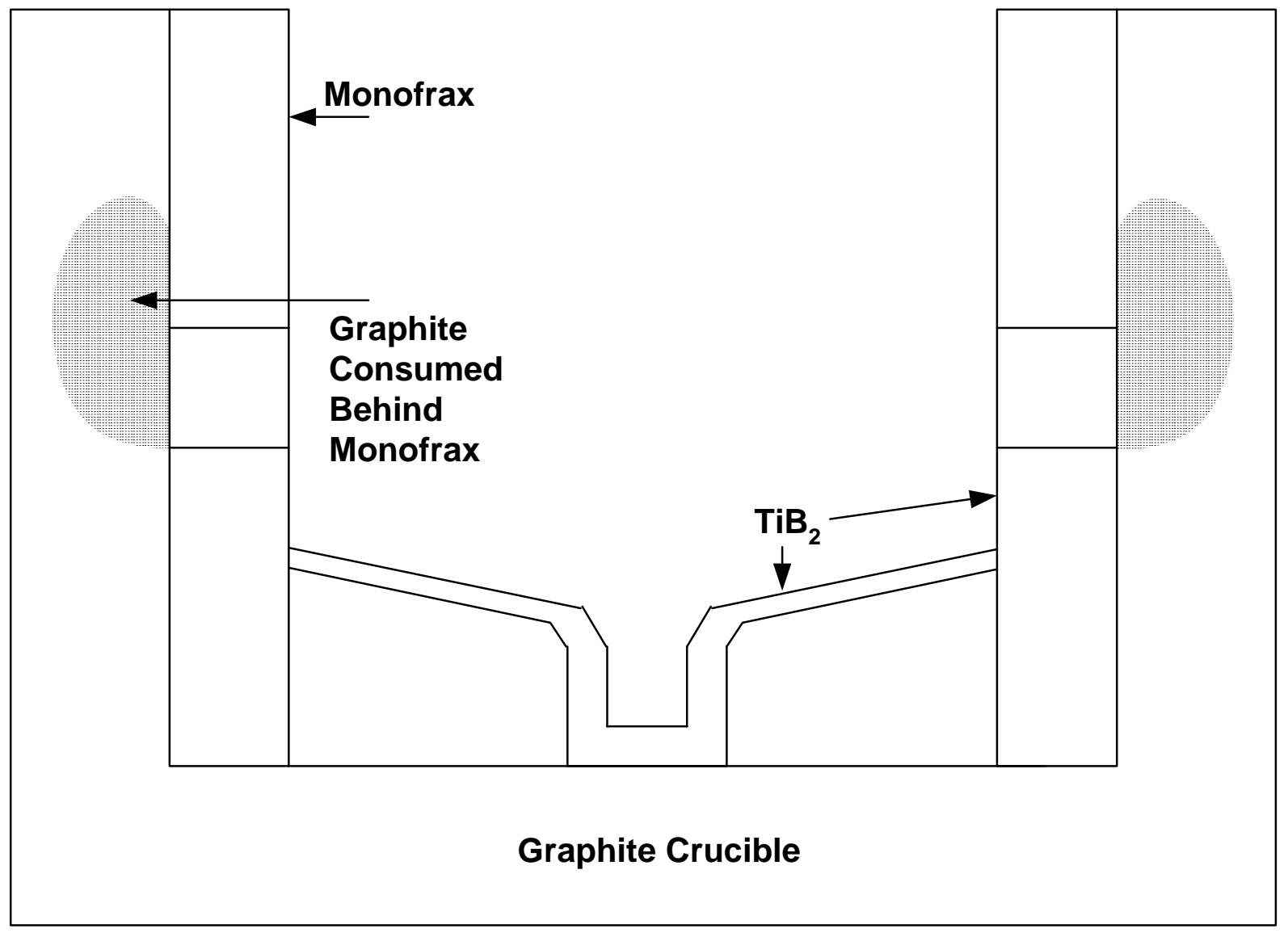

Figure 5.3-11-1 Attack on Graphite Crucible Behind Monofrax

The $\mathrm{TiB}_{2}-\mathrm{G}$ plates used to line the lower sidewalls, shelf floors and sump walls and floor were largely intact. The lower sidewall pieces were in very good shape, even retaining sharp edges. They were, however, not wetted on the inner vertical surface in most places. The shelf floors were wetted over most of the surface with 0.125-0.25 inches of aluminum. Only the inner edge nearest the sump was deteriorated. In that location, the $\mathrm{TiB}_{2}-\mathrm{G}$ was essentially gone. In the sump floor, the $\mathrm{TiB}_{2}-\mathrm{G}$ was wetted, but thinner than initially installed. Part of it may have dissolved away, but part was probably physically eroded during metal tapping, desludging and probing. Overall, the $\mathrm{TiB}_{2}-\mathrm{G}$ held up well and most, though not all, was wetted by aluminum.

The large graphite crucible was in very good shape and was re-useable.

Anode corrosion rates were determined by physically measuring thickness changes after the anodes were removed from the cell. An average wear of 1.57 inches/year was estimated by averaging many measurements from several anodes. Impurity levels in the aluminum slowly deteriorated over the course of the campaign. Fe rose from $0.42 \%$ to $8.9 \%$, Ni from $0.007 \%$ 
to $5.8 \%$, and $\mathrm{Cu}$ from $0.097 \%$ to $2.8 \%$. Bath was sampled routinely and analyzed regularly for ratio and alumina concentrations. Bath ratio varied widely as we fought temperature control issues from 1.03 to 1.22 with an average of 1.15. Alumina concentrations also varied as feed control and sludging both caused difficulties. Alumina varied from $6.0 \%$ to $10.7 \%$ with an average of $7.5 \%$. Some very high alumina concentrations of $13 \%$ were obtained from sludge samples from the bottom of the cell. Impurities in the bath were relatively low, $0.16 \% \mathrm{Fe}, 0.07 \% \mathrm{Ni}$ and $0.03 \% \mathrm{Cu}$.

Current efficiency was low in all three segments of the run. Best estimates are $23 \%, 24 \%$ and $36 \%$. These may be slightly low due to metal sample weights that were not accounted for. Regardless the metal rise in the crucible never approached the rate of rise expected at the current levels that we ran.

In conclusion, the horizontal pilot cell had two design defects: there was insufficient free bath surface area to permit easy feeding and there was insufficient top lid insulation which led to high heat losses and surface crusting. Changes made for the second half of the run did reduce top heat losses and solved the feeding/crusting problems.

\section{TASK 15: MODELING}

A physical model of a representative section of the commercial cell will be used to improve the alumina feeding strategy and the electrolyte circulation. The existing computer models for current efficiency and distribution will be improved and enhanced to include anode corrosion predictions based all available results. A see-in cell with longer life will be developed to allow visualization of interfacial processes on electrode surfaces - bubble formation at the anode and aluminum wetting of the cathode.

\subsection{Physical Modeling of Cell to Verify Interfacial Characteristics Prevent Mucking} See-in cells will be improved to extend their life for studying critical interfacial phenomena. This will include the study of bubble formation, growth and interaction to avoid foaming and current efficiency losses due to migration of small bubbles to the cathode. This work will visualize cathode wetting by aluminum to guarantee adequate drainage of aluminum from the electrode compartment. Inadequate drainage can lead to short circuiting and loss of current efficiency. A physical model of a representative section of the cell will be used to improve the alumina feeding strategy and the electrolyte circulation pattern in order to maintain correct alumina concentrations in the electrolyte and to develop methods for reducing sludge formation and/or removing it. Preventing "rafts" and distributing the feed are considered critical techniques for rapid feed dissolution without mucking. The primary choice for this work is a water model with gas bubbles piped into the anodes, but some consideration will be given to producing the bubbles by electrolysis using either an acidic or basic solution as an electrolyte.

A water model facility was set up to assess cell designs for the electrolyte circulation. The initial model was a horizontal anode cell configuration and assessed dissolution of $\mathrm{Al}_{2} \mathrm{O}_{3}$. 
Flow visualization techniques was used to provide qualitative measurements and Particle Image Velocimetry (PIV) was used for quantitative values. It was also used to assess the influence of anode gas evolution on metal pad movement and alumina dissolution. A water model of a 2" x 6" slice of a horizontal anode was tested. The anode was made from a block of porous carbon in a Plexiglas box. Isopropyl alcohol (2\%) was added to the water to reduce bubble size to those expect to be generated by an inert anode. It was important to obtain a uniform bubble layer under the anode. This was done by adjusting the spacing of holes in the porous block, improving the seal between the block and the box, and selecting the best porous media. The PIV system was used to measure a flow field generated by the bubbles.

In conclusion, the water model was very useful in understanding gas driven fluid flow under and around the horizontal anodes. Two different types of sloped gas channels were tested first in the water model and later in the horizontal pilot cell.

\subsection{CONCLUSIONS}

Phase III as originally proposed was focused on the operation of three pilot cells and the attainment of various operating parameters in those three pilots (see page 3 and the details on cell operability, cell performance, anode performance, alumina feed system and economic assessment). However, due to serious problems in attaining acceptable current efficiencies in bench vertical plate cells, the work was refocused into three areas: bench vertical plate cells, anode composition development and cathode wetting. Thus none of the original pilot goals were even tested let alone accomplished.

All of the milestones related to materials, in particular metal purity, were attained with distinct improvements over work in previous phases of the program. NiO additions to the ceramic phase and $\mathrm{Ag}$ additions to the $\mathrm{Cu}$ metal phase of the cermet improved corrosion resistance sufficiently that the bench scale pencil anodes met the purity milestones. Some excellent metal purity results have been obtained with anodes of the following composition: $14 \% \mathrm{Cu}, 3 \% \mathrm{Ag}, 83 \%$ composition 5301 (51.7\% $\mathrm{NiO}, 48.3 \% \mathrm{Fe}_{2} \mathrm{O}_{3}$.

Further improvements in anode material composition appear to be dependent on a better understanding of oxide solubilities in molten cryolite. For that reason, work was commissioned with an outside consultant to model the MeO-cryolite systems. That work has led to a better understanding of which oxides can be used to substitute into the $\mathrm{NiO}-\mathrm{Fe}_{2} \mathrm{O}_{3}$ ceramic phase to stabilize the ferrites and reduce their solubility in molten cryolite.

An extensive number of vertical plate bench electrolysis cells were run to try to find conditions where high current efficiencies could be attained. $\mathrm{TiB}_{2}-\mathrm{G}$ plates were very inconsistent and led to poor wetting and drainage. Pure $\mathrm{TiB}_{2}$ did produce good current efficiencies at small overlaps between the anodes and cathodes. This bench work with vertical plate anodes and cathodes reinforced the importance of good cathode wetting to attain high current efficiencies. Because of those conclusions, new wetting work was 
commissioned and became a major component of the research during the third year of Phase III.

While significant progress was made in several areas, much work needs to be done. The anode composition needs further improvements to attain commercial purity targets. At the present corrosion rate, the vertical plate anodes will wear too rapidly leading to a rapidly increasing anode-cathode gap and thermal instabilities in the cell. Cathode wetting as a function of both cathode plate composition and bath composition needs to be better understood to ensure that complete drainage of the molten aluminum off the plates occurs. Metal buildup appears to lead to back reaction and low current efficiencies. 


\subsection{APPENDICES}

\section{Appendix 1}

\section{Fabrication of 1/2” Diameter Inert Anodes}

Following are the procedures used in the fabrication and processing of the $1 / 2$ " diameter, graded connection, rounded bottom anodes, used in the DOE/Alcoa small Hall cell runs.

The powder used is a blend of spray dried 5324 composition material (5324 composition is a blend of 51.7 wt. $\% \mathrm{NiO}$ and 48.3 wt. $\% \mathrm{Fe}_{2} \mathrm{O}_{3}$ ), and $17 \%$ or $27 \%-325$ mesh, $99.5 \%$ pure copper metal powder, grade 165 .

These powders (5324 + copper) are weighed up in a jar. The jar is then mounted on a Fisher Kendall mixer, and tumbled for at least 4 hours at $60 \mathrm{rpm}$.

The powder for the graded connection is a blend of the spray dried $5324+$ copper (now referred to as "basic mix"), with 4 different percentages of nickel powder.

$90 \% \mathrm{Ni}$
$75 \% \mathrm{Ni}$
$50 \% \mathrm{Ni}$
$25 \% \mathrm{Ni}$

These powders are also blended using the Kendall mixer.

The powders are now blended and ready to be pressed into parts, using an isostatic press. The bags or molds are $\sim 11$ " long and $\sim 1$ " in diameter. The powder weights to be used have all been previously figured out, to give the apropriate size anode needed. The molds are filled, placing the basic mix in the mold first, then using the nickel gradients, in order of increasing Ni content, finally going to $90 \%$ nickel at the top. The powder lots are individually poured into the bag. Tapping the sides of the bag in between powder layers helps to level the top surfaces and settle the powder for pressing.

$$
\begin{aligned}
& 90 \% \mathrm{Ni} \\
& 75 \% \mathrm{Ni} \\
& 50 \% \mathrm{Ni} \\
& 25 \% \mathrm{Ni} \\
& 5324+17 \% \mathrm{Cu}
\end{aligned}
$$

After the molds have been filled, a sealing closure and ring are placed in the end of the bag and secured with a hose clamp. The filled molds are then placed into the vessel of the press and taken to 20,000 psi to 30,000 psi. The press goes from 0 psi to the setpoint in $\sim 3$ minutes. The setpoint is held for 1 minute. The pressure is then slowly released. The bags 
are then removed from the vessel, dried off, and the part is removed, being careful not to get it wet.

The green part is now ready for sintering. It is first placed in an alumina tray, using 28 mesh calcined alumina as a bed graini. The tray is then set on a " $\mathrm{D}$ " tube, and then slid into the 3" diameter tube of the $1700^{\circ} \mathrm{C}$ Lindberg tube furnace. The tray is positioned in the heat zone of the furnace. The tube is sealed by bolting a stainless flange on the open end, which has the argon inlet, exhaust, and thermocouple running through it.

The following program is then started:

Room temp to $400^{\circ} \mathrm{C} @ 144^{\circ} / \mathrm{hr}$

$1 \mathrm{hr}$ hold

$400^{\circ} \mathrm{C}$ to $1000^{\circ} \mathrm{C} @ 300^{\circ} / \mathrm{hr}$

$1000^{\circ} \mathrm{C}$ to $1350^{\circ} \mathrm{C} @ 175^{\circ} / \mathrm{hr}$

$2 \mathrm{hr}$ hold

$1350^{\circ} \mathrm{C}$ to $1000^{\circ} \mathrm{C} @ 100^{\circ} / \mathrm{hr}$

Natural furnace cool to room temp

*** Above temperatures are all internal tube temperatures.

*** The sample cannot be removed until the temp is around $150^{\circ} \mathrm{C}$

Argon (100-200 ppm oxygen) is used as a purge gas throughout the entire run, at 2.0 LPM. 


\section{Appendix 2}

\section{Patents Generated Under Contract}

\begin{tabular}{|c|c|c|c|c|c|c|c|c|c|c|}
\hline $\begin{array}{l}\text { Job. } \\
\text { No. }\end{array}$ & $\begin{array}{l}\text { Government } \\
\text { Contract No. } \\
\text { (Case No.) }\end{array}$ & Inventor(s) & Title & $\begin{array}{l}\text { Serial No. } \\
\text { Filing Date }\end{array}$ & $\begin{array}{l}\text { Patent No. } \\
\text { Issue Date }\end{array}$ & $\begin{array}{l}\text { Report IR } \\
\text { to Govt. }\end{array}$ & $\begin{array}{l}\text { Report U.S. } \\
\text { Filing to Govt. }\end{array}$ & $\begin{array}{l}\text { Report Foreign } \\
\text { Filing to Govt. }\end{array}$ & $\begin{array}{l}\text { Foreign } \\
\text { Filing } \\
\text { Date }\end{array}$ & $\begin{array}{l}\text { Send copy of } \\
\text { U.S. Patent } \\
\text { to Govt. }\end{array}$ \\
\hline $\begin{array}{l}\text { IP1998 } \\
003177 \\
\text { (GEK) }\end{array}$ & $\begin{array}{l}\text { DE-FC07- } \\
\text { 98ID13666 } \\
\text { (S-95,044) }\end{array}$ & $\begin{array}{c}\text { Ray, S.P. } \\
\text { Woods, R. W. } \\
\text { Dawless, R. K. } \\
\text { Hosler, R.B. }\end{array}$ & $\begin{array}{c}\text { Inert Electrode Containing } \\
\text { Metal Oxides, Copper, and } \\
\text { Noble Metal }\end{array}$ & $\begin{array}{c}241,518 \\
2 / 1 / 99\end{array}$ & $\begin{array}{c}6,126,799 \\
10 / 3 / 00\end{array}$ & - & $12 / 16 / 99$ & $12 / 8 / 00$ & $1 / 29 / 99$ & $10 / 6 / 00$ \\
\hline $\begin{array}{l}\text { IP1999 } \\
002106 \\
\text { (ELL) }\end{array}$ & $\begin{array}{l}\text { DE-FC07- } \\
\text { 98ID13666 } \\
(\mathrm{S}-95,045)\end{array}$ & $\begin{array}{l}\text { Ray, S. P. } \\
\text { Liu, X. }\end{array}$ & $\begin{array}{l}\text { Inert Anode Containing } \\
\text { Base Metal and Noble } \\
\text { Metal Useful for the } \\
\text { Electrolytic Production of } \\
\text { Aluminum } \\
\end{array}$ & $\begin{array}{l}428,004 \\
10 / 27 / 99\end{array}$ & $\begin{array}{c}6,162,334 \\
12 / 19 / 00\end{array}$ & - & $12 / 16 / 99$ & - & None & $1 / 5 / 01$ \\
\hline $\begin{array}{l}\text { IP1999 } \\
\text { 002381 } \\
\text { (ELL) }\end{array}$ & $\begin{array}{l}\text { DE-FC07- } \\
98 \text { ID13666 } \\
(\mathrm{S}-95,046) \\
\end{array}$ & $\begin{array}{c}\text { Ray, S. P. } \\
\text { Liu, X. } \\
\text { Weirauch, D. A. }\end{array}$ & $\begin{array}{l}\text { Electrolytic Production of } \\
\text { High Purity Aluminum } \\
\text { Using Inert Anodes }\end{array}$ & $\begin{array}{c}431,756 \\
11 / 1 / 99\end{array}$ & $\begin{array}{c}6,217,739 \\
4 / 17 / 01\end{array}$ & - & $11 / 4 / 99$ & $8 / 24 / 00$ & $10 / 27 / 00$ & $8 / 6 / 01$ \\
\hline $\begin{array}{l}\text { IP1999 } \\
002379 \\
\text { (ELL) }\end{array}$ & $\begin{array}{l}\text { DE-FC07- } \\
\text { 98ID13666 } \\
(\mathrm{S}-96,060)\end{array}$ & $\begin{array}{l}\text { Ray, S. P. } \\
\text { Weirauch, D. A. } \\
\text { Liu, X. }\end{array}$ & $\begin{array}{l}\text { Inert Anode Containing } \\
\text { Oxides of Nickel, Iron, and } \\
\text { Zinc Useful for the } \\
\text { Electrolytic Production of } \\
\text { Metals }\end{array}$ & $\begin{array}{c}542,318 \\
4 / 4 / 00\end{array}$ & & - & $8 / 24 / 00$ & $\begin{array}{l}\text { (will be done } \\
\text { when we get } \\
\text { filing particulars } \\
\text { from JHH) }\end{array}$ & $10 / 27 / 00$ & \\
\hline $\begin{array}{l}\text { IP1999 } \\
002378 \\
(\text { ELL) }\end{array}$ & $\begin{array}{l}\text { DE-FC07- } \\
\text { 98ID13666 } \\
\text { (S-96,061) }\end{array}$ & $\begin{array}{l}\text { Ray, S. P. } \\
\text { Weirauch, D. A. } \\
\text { Liu, X. }\end{array}$ & $\begin{array}{l}\text { Inert Anode Containing } \\
\text { Oxides of Nickel, Iron, and } \\
\text { Cobalt Useful for the } \\
\text { Electrolytic Production of } \\
\text { Metals } \\
\end{array}$ & $\begin{array}{c}542,320 \\
4 / 4 / 00\end{array}$ & & - & $8 / 24 / 00$ & $\begin{array}{l}\text { (will be done } \\
\text { when we get } \\
\text { filing particulars } \\
\text { from JHH) }\end{array}$ & $10 / 27 / 00$ & \\
\hline
\end{tabular}




\begin{tabular}{|c|c|c|c|c|c|c|c|c|c|c|}
\hline $\begin{array}{l}\text { Job. } \\
\text { No. }\end{array}$ & $\begin{array}{l}\text { Government } \\
\text { Contract No. } \\
\text { (Case No.) }\end{array}$ & Inventor(s) & Title & $\begin{array}{l}\text { Serial No. } \\
\text { Filing Date }\end{array}$ & $\begin{array}{l}\text { Patent No. } \\
\text { Issue Date }\end{array}$ & $\begin{array}{c}\text { Report IR } \\
\text { to Govt. }\end{array}$ & $\begin{array}{l}\text { Report U.S. } \\
\text { Filing to Govt. }\end{array}$ & $\begin{array}{l}\text { Report Foreign } \\
\text { Filing to Govt. }\end{array}$ & $\begin{array}{l}\text { Foreign } \\
\text { Filing } \\
\text { Date }\end{array}$ & $\begin{array}{l}\text { Send copy of } \\
\text { U.S. Patent } \\
\text { to Govt. }\end{array}$ \\
\hline $\begin{array}{l}\text { IP1998 } \\
003177 \\
\text { (GEK) }\end{array}$ & $\begin{array}{l}\text { DE-FC07- } \\
\text { 98ID13666 } \\
(\mathrm{S}-96,059)\end{array}$ & $\begin{array}{c}\text { Ray, S. P. } \\
\text { Woods, R. W. } \\
\text { Dawless, R. K. } \\
\text { Hosler R. B. } \\
\end{array}$ & $\begin{array}{c}\text { Inert Electrode Containing } \\
\text { Metal Oxides, Copper, and } \\
\text { Noble Metal }\end{array}$ & $\begin{array}{l}621,728 \\
7 / 24 / 00\end{array}$ & & - & $8 / 24 / 00$ & - & None & \\
\hline $\begin{array}{l}\text { IP1999 } \\
002380 \\
(\text { ELL) }\end{array}$ & $\begin{array}{l}\text { DE-FC07- } \\
\text { 98ID13666 } \\
(\mathrm{S}-96,017)\end{array}$ & $\begin{array}{c}\text { Ray, S. P. } \\
\text { Liu, X. } \\
\text { Weirauch, D. A. }\end{array}$ & $\begin{array}{c}\text { Cermet Inert Anode } \\
\text { Containing Oxide and } \\
\text { Metal Phases Useful for the } \\
\text { Electrolytic Production of } \\
\text { Metals } \\
\end{array}$ & $\begin{array}{c}629,332 \\
8 / 1 / 00\end{array}$ & & - & $8 / 14 / 00$ & $\begin{array}{l}\text { (will be done } \\
\text { when we get } \\
\text { filing particulars } \\
\text { from JHH) }\end{array}$ & $10 / 27 / 00$ & \\
\hline $\begin{array}{l}\text { IP2001 } \\
001396 \\
\text { (ELL) }\end{array}$ & $\begin{array}{l}\text { DE-FC07- } \\
\text { 98ID13666 }\end{array}$ & $\begin{array}{c}\text { Ray. S. P. } \\
\text { Liu, X. } \\
\text { Weirauch, D. A. } \\
\text { DiMilia, R. A. } \\
\text { Dynys, J. M. } \\
\text { Phelps, F. E. } \\
\text { LaCamera, A. F. }\end{array}$ & $\begin{array}{c}\text { Electrolytic Production of } \\
\text { High Purity Aluminum } \\
\text { Using Ceramic Inert } \\
\text { Anodes }\end{array}$ & $\begin{array}{l}835,595 \\
4 / 16 / 01\end{array}$ & & - & $5 / 4 / 01$ & - & None & \\
\hline
\end{tabular}

